\title{
Republic of Yemen: 2007 Article IV Consultation-Staff Report; Staff Supplements; Public Information Notice on the Executive Board Discussion; and Statement by the Executive Director for the Republic of Yemen
}

Under Article IV of the IMF's Articles of Agreement, the IMF holds bilateral discussions with members, usually every year. In the context of the 2007 Article IV consultation with the Republic of Yemen, the following documents have been released and are included in this package:

- The staff report for the 2007 Article IV consultation, prepared by a staff team of the IMF, following discussions that ended on June 13, 2007, with the officials of the Republic of Yemen on economic developments and policies. Based on information available at the time of these discussions, the staff report was completed on August 17, 2007. The views expressed in the staff report are those of the staff team and do not necessarily reflect the views of the Executive Board of the IMF.

- $\quad$ A supplement on the joint IMF/World Bank debt sustainability analysis.

- $\quad$ A staff supplement of September 13, 2007 updating information on recent developments.

- $\quad$ A Public Information Notice (PIN) summarizing the views of the Executive Board as expressed during its September 17, 2007 discussion of the staff report that concluded the Article IV consultation.

- $\quad$ A statement by the Executive Director for the Republic of Yemen.

The document listed below has been or will be separately released.

Statistical Appendix

The policy of publication of staff reports and other documents allows for the deletion of market-sensitive information.

To assist the IMF in evaluating the publication policy, reader comments are invited and may be sent by e-mail to publicationpolicy@imf.org.

Copies of this report are available to the public from

International Monetary Fund • Publication Services

$70019^{\text {th }}$ Street, N.W. • Washington, D.C. 20431

Telephone: (202) 623-7430 • Telefax: (202) 623-7201

E-mail: publications@imf.org • Internet: http://www.imf.org

Price: $\$ 18.00$ a copy

\section{International Monetary Fund Washington, D.C.}





\section{INTERNATIONAL MONETARY FUND}

\section{REPUBLIC OF YEMEN}

\section{Staff Report for the 2007 Article IV Consultation}

Prepared by the Staff Representatives for the 2007 Consultation

with the Republic of Yemen

Approved by Adam Bennett and Adnan Mazarei

August 17, 2007

- The 2007 Article IV consultation discussions were held in Sana'a during May 31-June 13, 2007, with the prime minister; the deputy prime minister and minister of planning and international cooperation; the ministers of finance, oil and minerals, industry and trade, civil service, and social affairs and labor; the governor of the central bank, and other government officials. The mission also met with various private sector representatives and donors.

- The staff team comprised Messrs. van Rooden (head) and Davoodi, Mses. Guin-Siu, Jardaneh, and Naqi (all MCD), and Mr. Kato (PDR). Mr. Bennett (MCD) joined the discussions for a few days.

- Yemen has accepted the obligations of Article VIII, Sections 2, 3, and 4, and maintains an exchange system that is free of restrictions on the making of payments and transfers for current international transactions.

- The Yemeni authorities maintain that the exchange rate system is an independent float. Staff are of the view that de facto it is a crawling peg, in which the rate of crawl has recently slowed to resemble a conventional peg. Accordingly, under the IMF's classification, Yemen is currently considered a de facto conventional peg.

- The quality and timeliness of data are weak, but still adequate for surveillance purposes. Yemen participates in the General Data Dissemination Standard. 


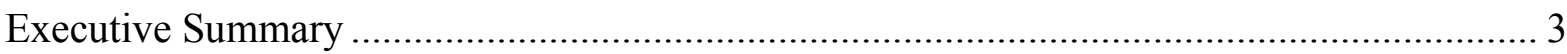

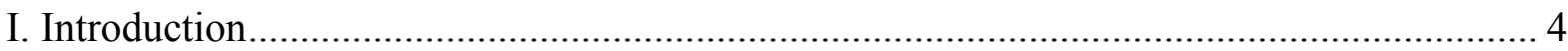

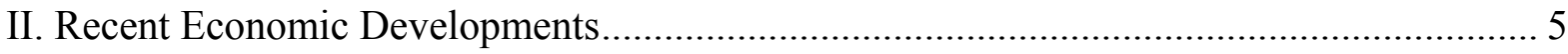

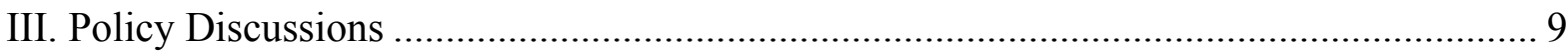

A. Policies for 2007: Reducing Inflation ............................................................ 10

B. Medium-Term Policies: Ensuring Fiscal Sustainability ........................................ 13

C. Medium-Term Policies: Promoting Sustained Nonhydrocarbon Growth ............... 16

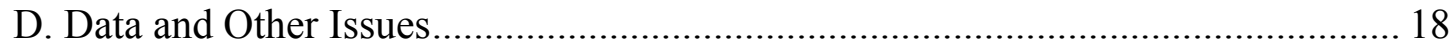

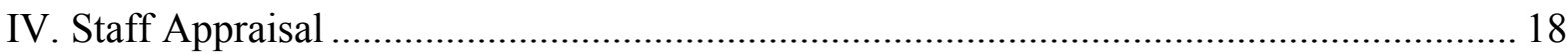

Tables

1. Selected Economic Indicators (Adjustment scenario), 2003-12 ….................................. 20

2. General Government Finances (Adjustment scenario), 2003-12 …................................. 21

3. General Government Finances (Adjustment scenario), 2003-12 (in percent of GDP) ....... 22

4. Monetary Aggregates (Adjustment scenario), 2000-07 ………....................................... 23

5. Balance of Payments (Adjustment scenario), 2003-12 …................................................. 24

Figures

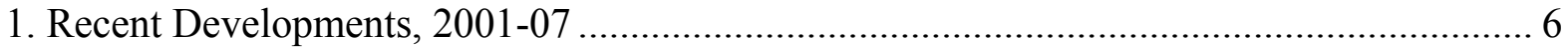

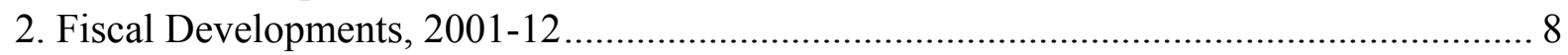

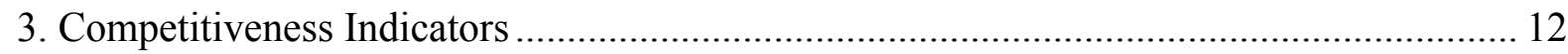

Boxes

1. Implementation of Past IMF Recommendations ………................................................ 5

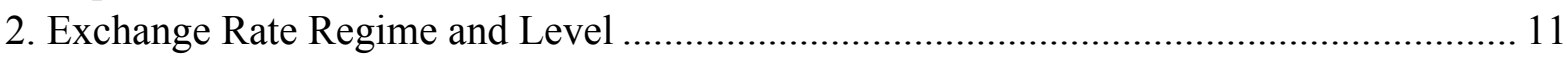

3. Hydrocarbon Sector Developments and Prospects ......................................................... 14 


\section{EXECUTIVE SUMMARY}

\section{Focus of the report}

The discussions for the 2007 Article IV consultation focused on the need to (i) bring down inflation; (ii) achieve fiscal sustainability in the context of declining oil reserves; and (iii) promote nonhydrocarbon growth to create employment opportunities and reduce poverty.

\section{Background}

Economic performance in Yemen in 2006 was generally favorable, with strong non-oil growth more than offsetting a decline in oil production, but inflation doubled to over 20 percent. The higher inflation partly reflected rising world food prices, but also buoyant domestic demand, driven by high government spending from record oil revenues - including a large wage increase - and rapid money growth. Inflation slowed in early 2007 due to seasonal factors. As oil could run out in some 10 years time and oil revenues account for three-fourths of government revenues, fiscal (and external) sustainability would be at risk without a large fiscal adjustment. Fuel subsidies take up a large part of government spending and exceed non-oil tax revenues. Without corrective actions, or major new oil or gas finds, government finances would deteriorate rapidly in the coming years, risking domestic and external instability.

\section{Authorities' views}

The authorities agreed to effect a modest tightening of fiscal and monetary policies to bring down inflation. They intend to delay a large government wage increase planned for 2007 and compress other expenditures as much as possible. The central bank will more actively mop up excess liquidity and will aim to slow down the nominal depreciation of the currency.

The authorities acknowledged that fiscal policy, if unchanged, was unsustainable, and that the key to achieving sustainability lies with increasing non-oil revenues and rationalizing spending, including the elimination of fuel subsidies. They noted that the latter was likely to be delayed due to political economy considerations and weaknesses in the social safety net. Efforts to improve tax collection faced strong opposition from the business community. The authorities were hopeful that new oil and gas reserves could ease the adjustment process.

\section{Staff recommendations}

Staff welcomed the authorities' efforts to reduce inflation, but argued that some nominal appreciation in the short run could help bring down inflation further, also as the exchange rate appears slightly undervalued. Eliminating the minimum interest rate for local currency deposits would allow for a more active interest rate policy and would enhance financial intermediation.

Staff urged the authorities to consider a more front-loaded fiscal adjustment, by taking early steps to reduce fuel subsidies and making stronger efforts to raise non-oil tax revenues. Staff stressed, however, that reducing fuel subsidies should be accompanied by measures to strengthen the social safety net to mitigate the impact on the poor. 


\section{INTRODUCTION}

1. Yemen remains one of the poorest countries in the Middle East. It is ranked $150^{\text {th }}$ out of 177 countries in the 2006 United Nations Human Development Index. Strong oil revenues, especially in recent years, have permitted large increases in government spending. Together with sizable private transfers, this has contributed to a welcome decline in poverty, which has fallen from 40 percent in 1998 to 35 percent in 2006. Real per capita GDP, however, has been improving only slowly, reflecting Yemen's high rate of population growth. Similarly, unemployment has been rising, from 12 percent in 1999 to $16 \frac{1}{2}$ percent in 2006, as labor force growth has been outpacing job creation. Yemen will face difficult challenges meeting the Millennium Development Goals.

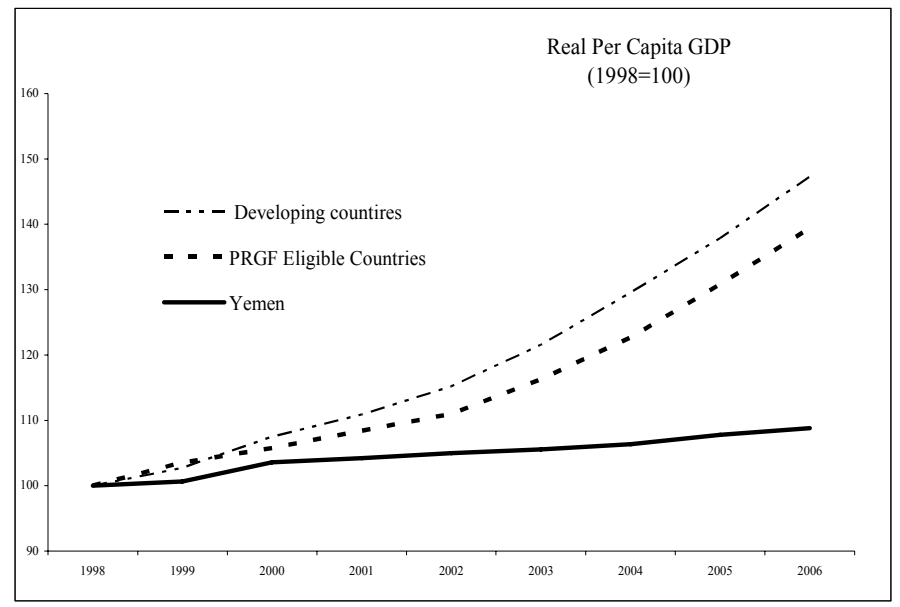

Sources: WEO database; Yemeni authorities

2. High oil revenues have reduced the urgency to advance economic reforms. The pace of implementation of IMF recommendations has slowed down significantly since the end of the last Fund-supported program in 2001 (Box 1).

\section{Relations with the international community have strengthened in recent years.}

External official assistance to Yemen has started to increase again, although aid has been relatively low in per capita terms. A Consultative Group (CG) meeting held November 2006 in London succeeded in generating almost $\$ 5$ billion in pledges (23 percent of 2006 GDP, Text Table 1), underwriting a large part of Yemen's Public Investment Program (PIP) for 2007-10.

Text Table 1. Yemen: Consultative Group Pledges

\begin{tabular}{|c|c|c|c|}
\hline \multirow[b]{3}{*}{ GCC countries } & Grants & Soft Loans & Total \\
\hline & \multicolumn{3}{|c|}{ (In millions of US\$) } \\
\hline & 1,950 & 350 & 2,300 \\
\hline Other bilateral donors & 785 & 65 & 850 \\
\hline Multilateral donors & 222 & 1,610 & 1,832 \\
\hline Total & 2,957 & 2,025 & 4,982 \\
\hline
\end{tabular}

Source: Yemeni authorities.

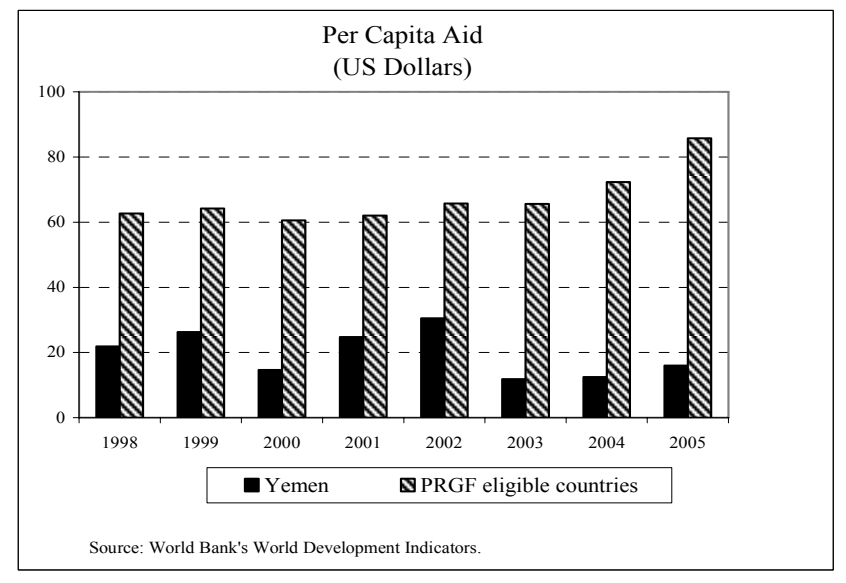




\section{Box 1. Implementation of Past IMF Recommendations}

Fiscal policy: A General Sales Tax (GST) was introduced in 2007, after seven years of preparation, but with concessions regarding the valuation of imports to gain support from the business community. Full implementation is now envisaged only in early 2009. Customs tariffs were substantially reduced in 2006. Generous tax exemptions remain. The tax administration is moving towards a functionalbased organizational structure and use of self assessment, but progress has been slow. A large tax payer unit was established. The authorities have not begun phasing out fuel subsidies, except for a one-time increase in domestic fuel prices in July 2005.

Monetary and exchange rate policy: Full liberalization of interest rates is yet to be implemented. Monetary policy remains geared more toward targeting the exchange rate than toward controlling inflation. Banking sector supervision needs to be strengthened and staff has repeatedly encouraged the authorities to request an update of the 2001 FSAP.

Structural reforms: Staff has called for reforms that boost private sector growth through improving the business climate and governance. New procurement legislation and implementation regulations have been prepared.

Macroeconomic data: Progress has been made in improving statistics, notably in monetary, balance of payments, and fiscal data, but further efforts are needed to improve the quality, timeliness and dissemination of Yemen's statistics. Areas particularly in need of improvement include national accounts and price statistics.

Half of the pledges came from Gulf Cooperation Council (GCC) countries. The authorities are working to finalize the individual project agreements with each of the donors. Yemen was reinstated in the U.S.'s Millennium Challenge Corporation's threshold program.

\section{RECENT ECONOMIC DEVELOPMENTS}

\section{Economic performance was generally favorable in $\mathbf{2 0 0 6}$, but inflation accelerated:}

- $\quad$ Output is estimated to have grown by about 4 percent, with almost 6 percent non-oil growth offsetting an 8 percent decline in oil production (Table 1 and Figure 1).

- $\quad$ Core annual average inflation (excluding the volatile prices of the narcotic qat) rose to over 20 percent, after a decade of relatively stable inflation in the 10-12 percent range. This partly reflected exogenous supply factors, particularly a rise in world food prices. But buoyant domestic demand, driven by high government spending - including a large wage increase - and rapid money growth, also played a major role. 
Figure 1. Yemen: Recent Developments, 2001-07

Despite declining oil production...

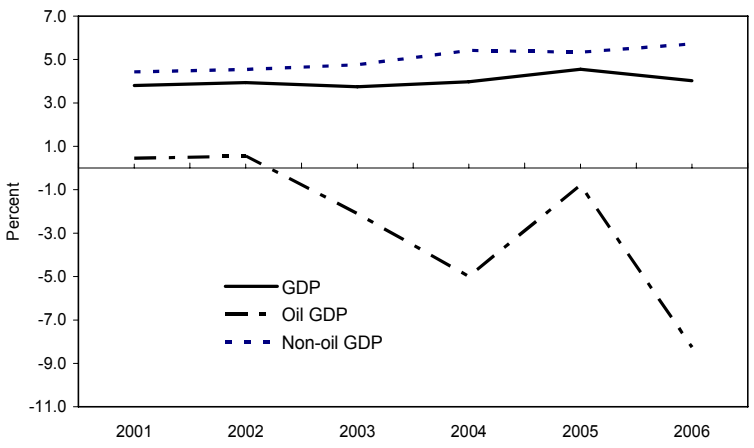

The real effective exchange rate appreciated, but with the CBY targeting a nominal depreciation...

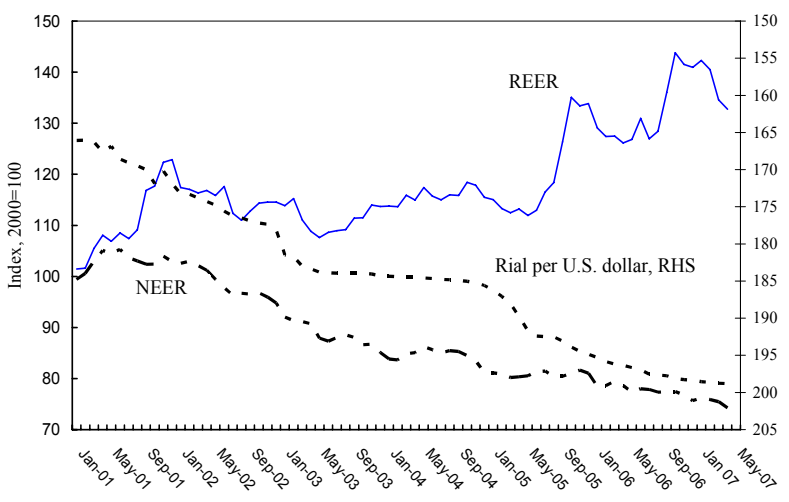

....and accelerating money growth.

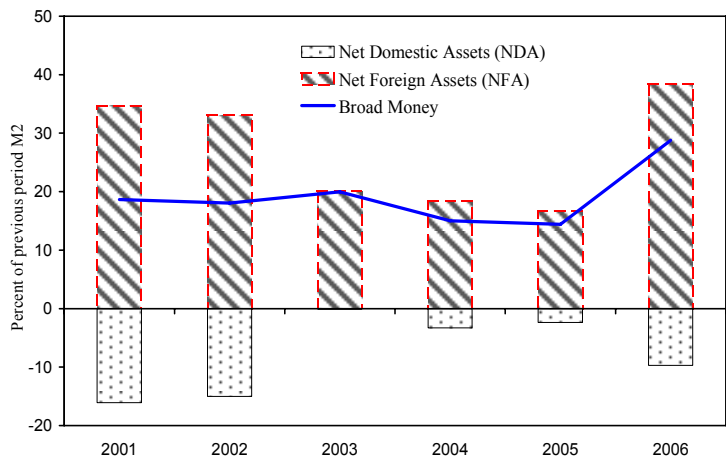

Sources: Yemeni authorities; and Fund staff estimates.

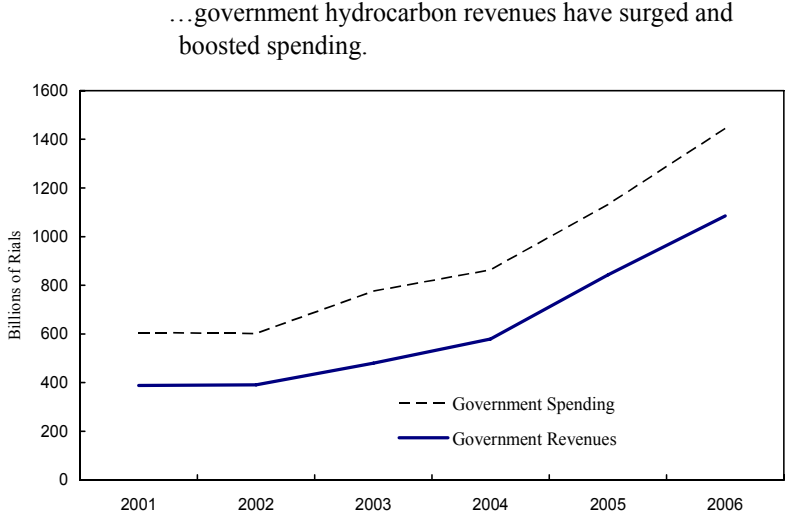

...this has resulted in high inflation...

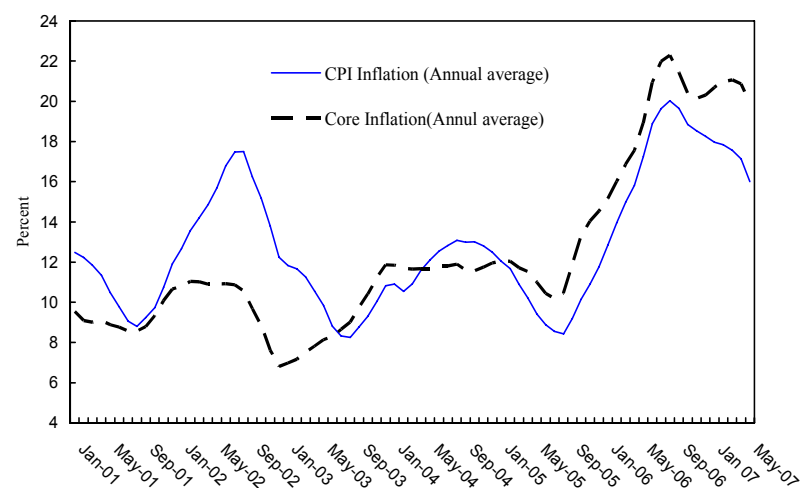

Almost all of the recent real appreciation has been achieved through higher inflation.

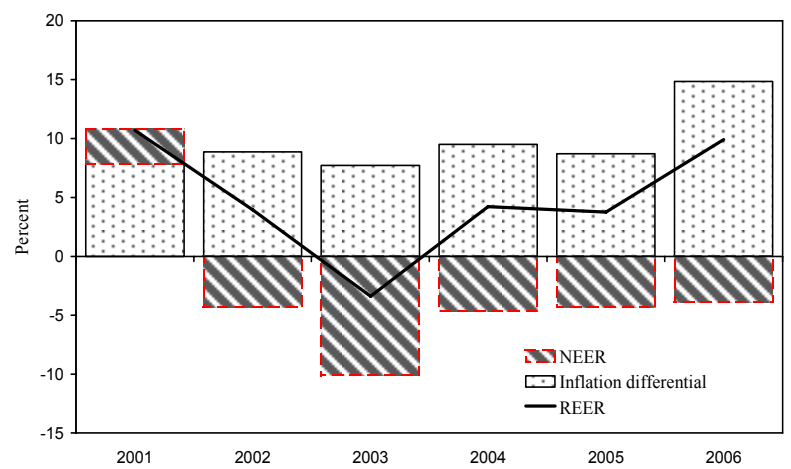


- Government expenditures fueled domestic demand, as higher-than-budgeted oil revenues were largely spent (Tables 2 and 3, Figure 2). As in 2005, the additional oil revenues helped contain the overall deficit to less than 1 Text Table 2. Yemen: Use of Extra Oil Revenues 2003-06 (In percent of GDP) percent of GDP, but the non-oil primary deficit widened to over 38 percent of non-oil GDP. Since 2002, when the run up in oil prices started, additional oil revenues have been mostly used to finance (fuel) subsidies and development spending, and to a lesser extent for government wage increases and social spending (Text Table 2). Non-oil tax revenues fell to less than 7 percent of GDP in 2006, well below the regional average and falling short of covering either the wage bill or fuel subsidies.

- $\quad$ Monetary policy was accommodative. With sizable government spending out of high oil revenues, the real exchange rate has continued to appreciate, by 10 percent. But with the Central Bank of Yemen (CBY) targeting a very slow, but steady depreciation of the exchange rate, similar to a de facto crawling peg - the rial depreciated a little less than 2 percent against the U.S. dollar during the year- the real appreciation has manifested itself through higher inflation. Money growth accelerated to 29 percent, twice the rate of the previous two years (Table 4). Despite the higher inflation, the benchmark deposit interest rate remained unchanged at 13 percent and domestic currency interest rates became negative in real terms.

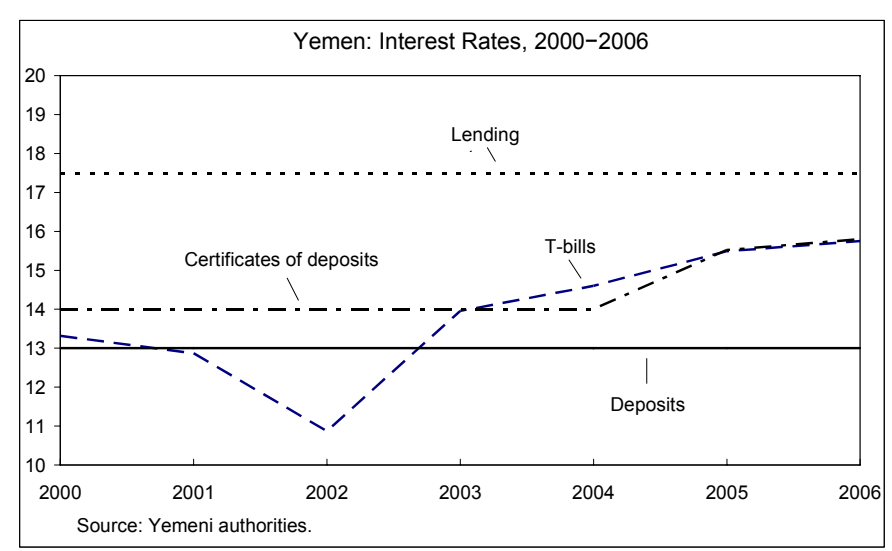


Figure 2. Yemen: Fiscal Developments, 2001-12

Revenues by Source 2001-2012

(in percent of GDP)

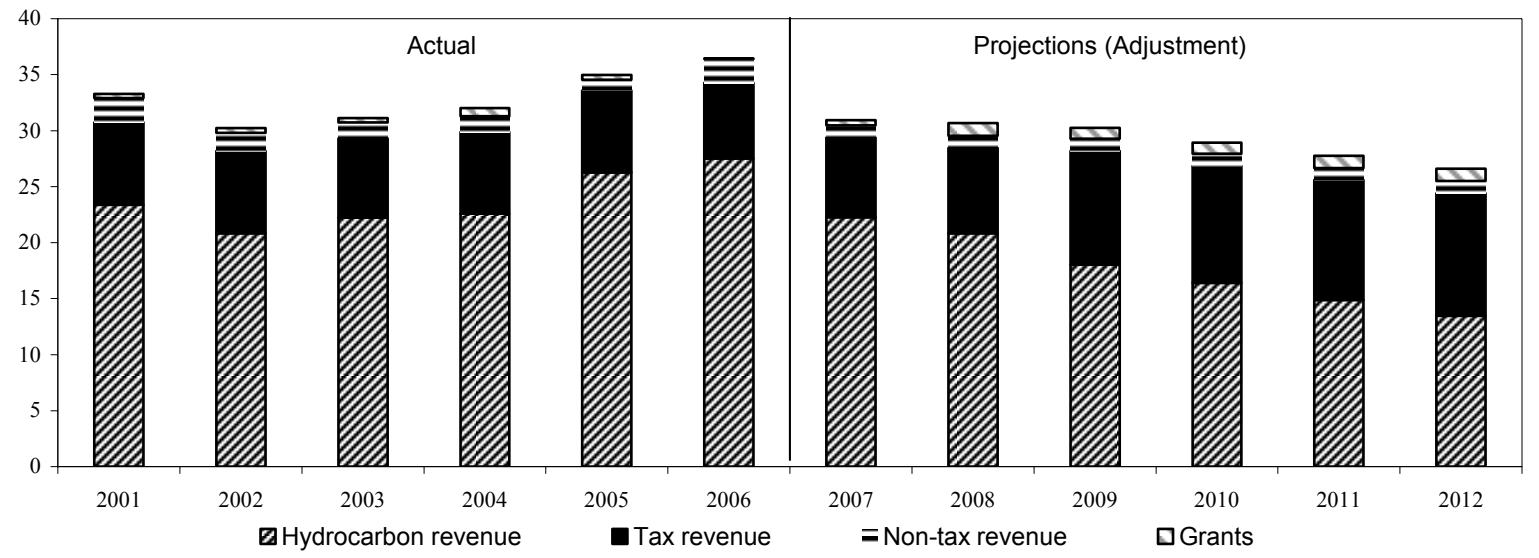

Expenditures and Net Lending 2001-2012

(in percent of GDP)

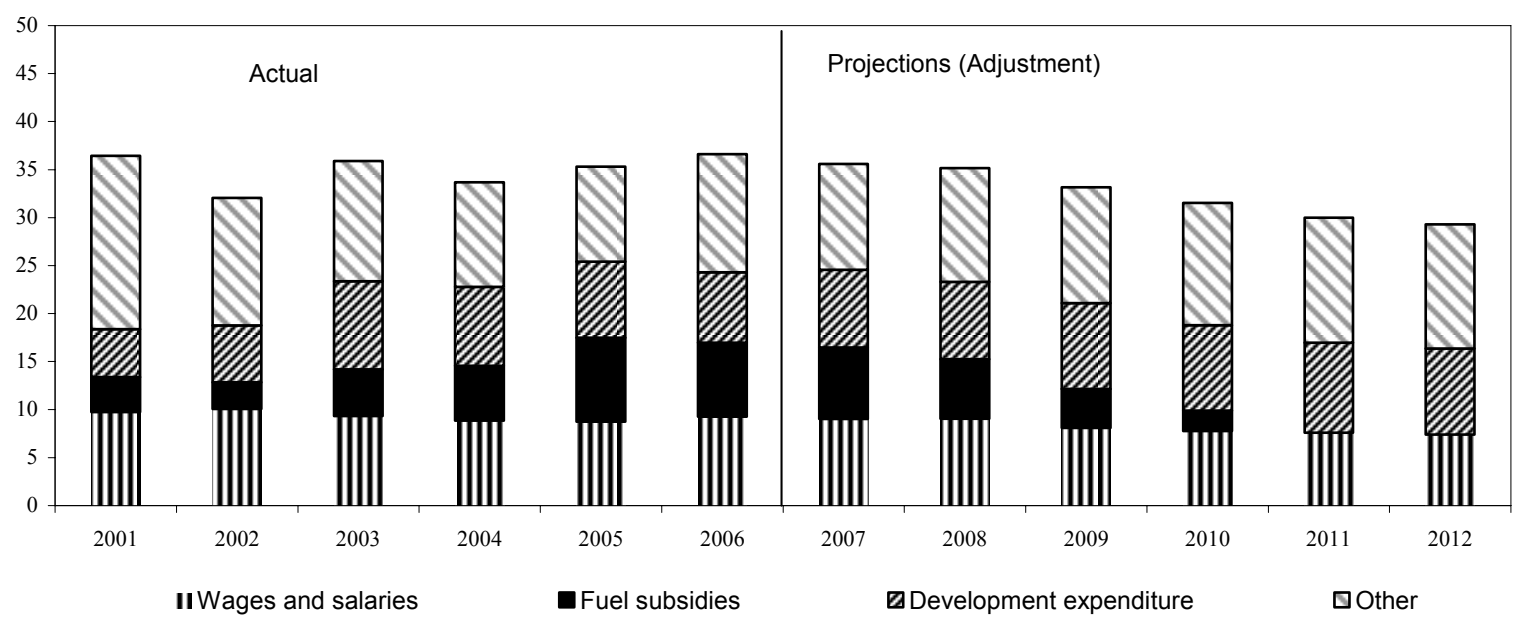

Budgetary Indicators, 2001-2012

(In percent of GDP)

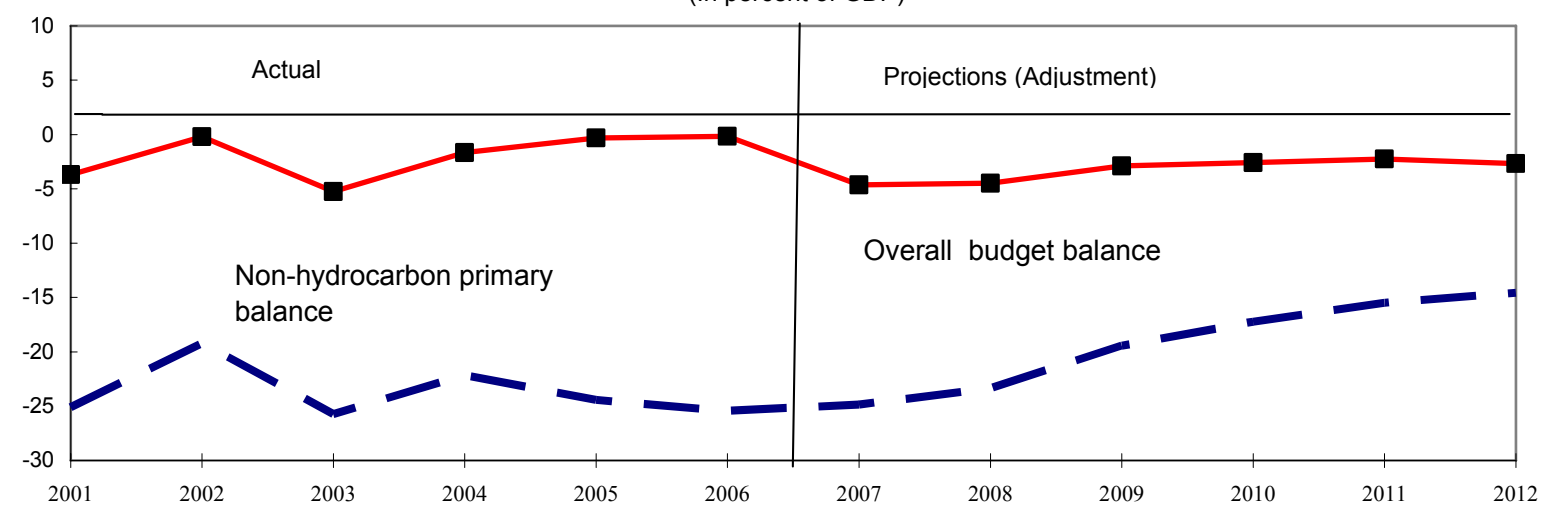

Sources: Ministry of Finance and Fund staff estimates. 
- $\quad$ The current account surplus remained broadly unchanged, at over 3 percent of GDP, with record-high oil receipts partially offset by imports related to sizable investment in the gas sector (Table 5). With the latter financed through foreign direct investment, the high oil revenues resulted in a large reserve accumulation by the CBY. Gross reserves increased by $\$ 1.5$ billion to $\$ 6.8$ billion by year end, the equivalent of about 11 months of imports.

Hydrocarbon exports and current account balance

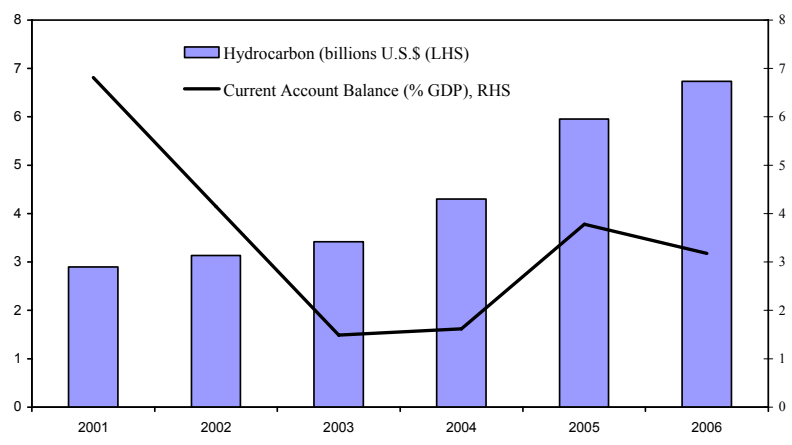

Sources: Yemeni authorities; and Fund staff estimates.
CBY reserves

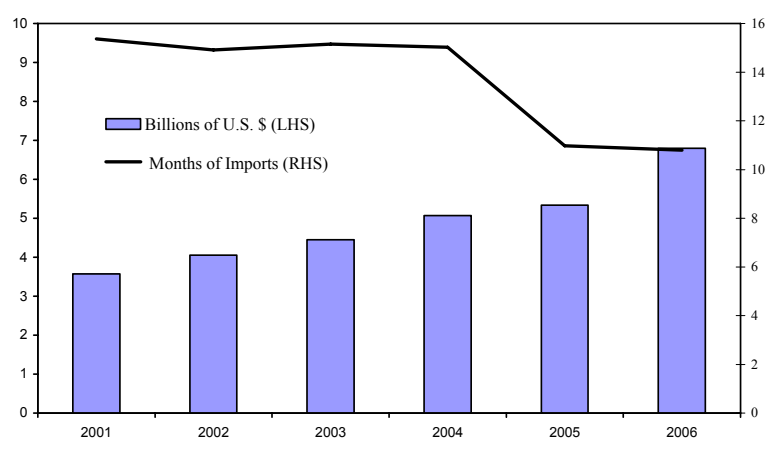

5. Inflationary pressures eased in early 2007 , partly reflecting seasonal factors, but also because government spending was contained in the first quarter. Twelve-month core inflation fell to 12 percent in May 2007, mainly reflecting a very large drop in the prices of vegetables due to good rains. Annual average core inflation still stood at 20 percent in May. Partial data suggest that government spending remained below budgeted amounts in the first few months of the year as oil exports lagged behind annual forecasts. With less inflows, money growth slowed down, to 25 percent by end-May.

6. The approved 2007 budget envisages a significant increase in the deficit, to 6 percent of GDP. The budget maintains high spending levels and includes another wage increase of 20-25 percent, despite a sharp drop in oil revenues due to declining production and prices. Consolidating the PIP and related donor flows (which were not included in the budget) with the budget would further increase the overall deficit to 7 percent of GDP.

\section{Policy Discussions}

\section{Against this backdrop, the 2007 Article IV consultation discussions focused on} three key macroeconomic challenges:

- bringing inflation down to levels below 10 percent, to prevent expectations of high inflation from becoming entrenched; 
- $\quad$ achieving fiscal sustainability in the context of declining oil reserves; and

- $\quad$ promoting nonhydrocarbon growth to create employment opportunities and help achieve a lasting reduction in poverty.

\section{A. Policies for 2007: Reducing Inflation}

8. The authorities recognized the need to reduce inflation and agreed to undertake a modest tightening of fiscal and monetary policies. They realized that the planned wage increase would fuel inflation pressures. They agreed to delay the increase, at least until the associated civil service reforms (including the introduction of biometric cards) are fully implemented (expected by early or mid-2008 for most ministries). However, military wages were raised already, in light of the recent violence in the northern part of the country. Other nonwage current spending will be compressed. The authorities will also consider some streamlining of the budget's own capital spending with the start of some of the (off-budget) development projects financed from last year's CG pledges. Combined, these actions could reduce the 2007 budget deficit by some 2 percent of GDP. The CBY will resume issuing treasury bills in amounts above those required to finance the budget deficit, to mop up excess liquidity, and may resort to issuing its own certificates of deposit as well. With implementation of these measures, staff estimates that core inflation, which ended 2006 at 22 percent, could be reduced to about 12-14 percent by end-2007.

9. To help bring down inflation more firmly, especially as the wage increase will only be delayed, staff urged the authorities to allow some nominal appreciation of the rial and to liberalize, and possibly raise, interest rates. Yemen is a highly dollarized and largely cashoriented economy, with a strong exchange rate pass-through, which makes the exchange rate a more effective monetary tool to influence inflation (and the incentives to dollarize) than interest rate policy. With CBY foreign exchange reserves at a comfortable level, staff advised the CBY to increase its sales of foreign exchange in order to at least halt the depreciation of the rial, but possibly even to allow some nominal appreciation in the short run, as the rial seems to be moderately undervalued at the present time (Box 2).

10. The authorities agreed to slow the rate of depreciation of the rial, but were reluctant to allow a nominal appreciation, for fear of losing reserves and hurting competitiveness. Mindful of the prospective decline in oil reserves over the medium term, the authorities wish to preserve foreign exchange reserves as much as possible. Staff acknowledged that competitiveness, which already appears low (Figure 3), could suffer, but argued that the adverse impact of high inflation on the overall economy was likely to outweigh any dampening effects of an appreciation on non-oil exports. Moreover, competitiveness could be undermined as much from inflation as from a stronger exchange rate. 


\section{Box 2. Exchange Rate Regime and Level}

The nominal exchange rate of the rial vis-à-vis the U.S. dollar has been slowly, but steadily depreciating over the past several years, in a de facto crawling peg, in which the rate of crawl has recently slowed to resemble a conventional peg. While the rial depreciated by on average $3 \frac{1}{4}$ percent per year since 2000 , the rate of depreciation slowed to a little less than 2 percent in 2006 and to 1 percent in the 12 months through June 2007. Most of Yemen's foreign exchange inflows accrue to the CBY. The CBY supplies foreign exchange to the market through its foreign exchange auctions, which are held irregularly and infrequently. The timing of, and the amounts sold at, the auctions are determined so to achieve a slow depreciation. The authorities, however, maintain that the exchange rate regime is an independent float and that the rial is appropriately valued.
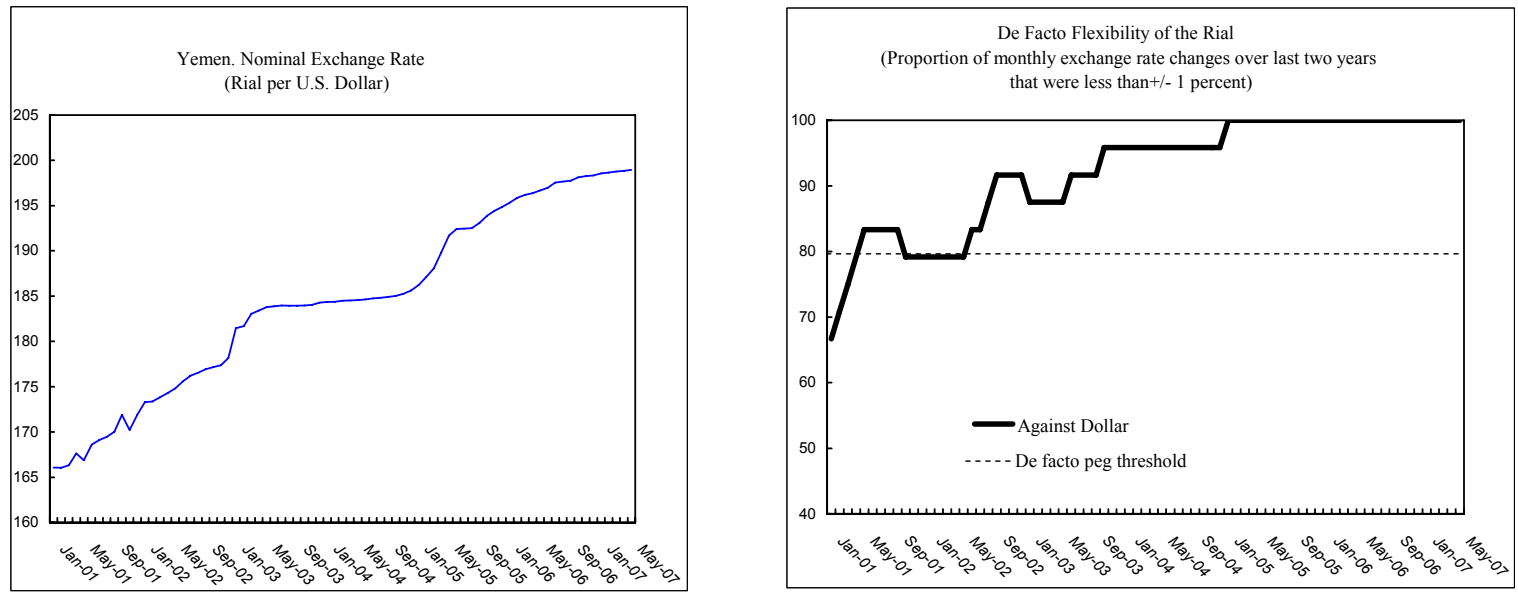

Central Bank Monthly Foreign Exchange Sales
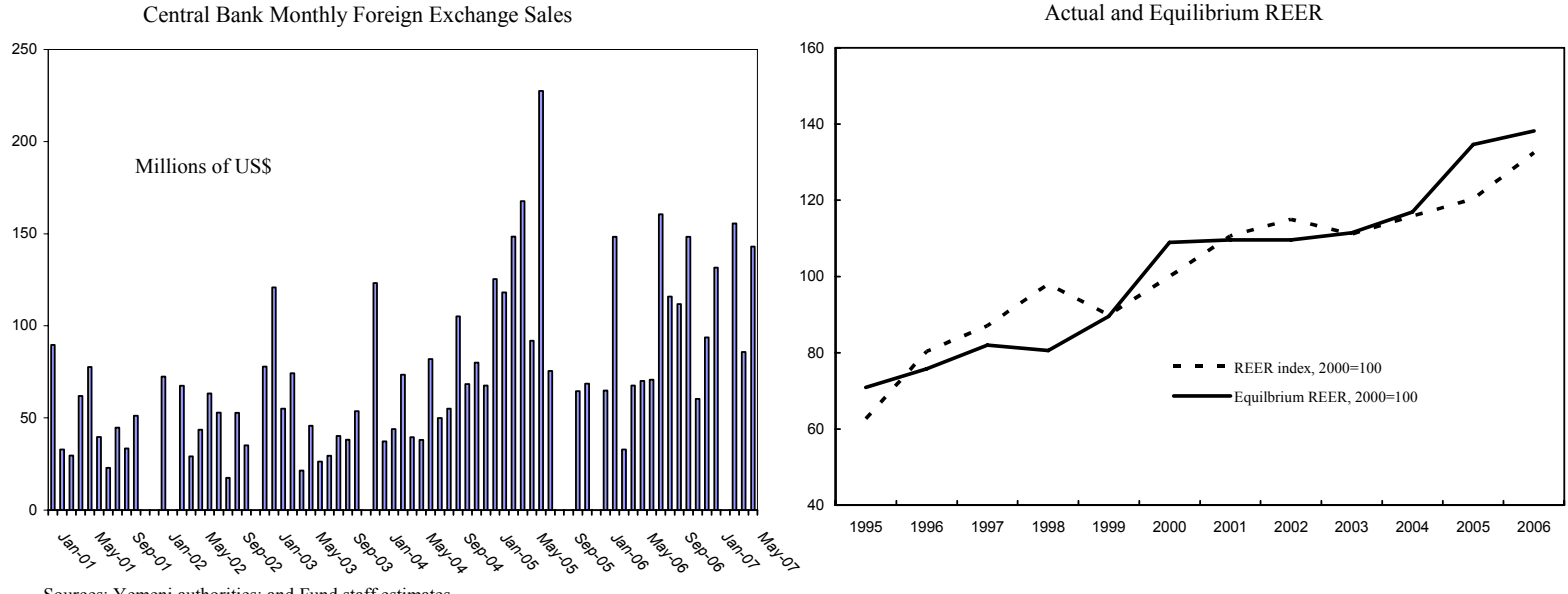

There is no evidence of a major exchange rate misalignment. Yemen's real effective exchange rate (REER) has been appreciating as in many oil-producing countries, but this appreciation has come primarily through higher inflation, given the CBY's exchange rate policy. Estimates of the equilibrium REER (subject to very large margins of statistical uncertainty) based on the Consultative Group on Exchange Rate's equilibrium real exchange rate approach suggest a modest undervaluation of Yemen's REER by about 5 percent in 2006, well within the margin of error.

Over time, if Yemen's oil runs out, the equilibrium real exchange rate can be expected to be much more depreciated than today. An assessment of Yemen's REER factoring in the decline in oil production, suggests that the equilibrium REER may be some 30-40 percent more depreciated over the longer term than its current level. 
Figure 3. Yemen: Competitiveness Indicators

Yemen's nonhydrocarbon exports are low.

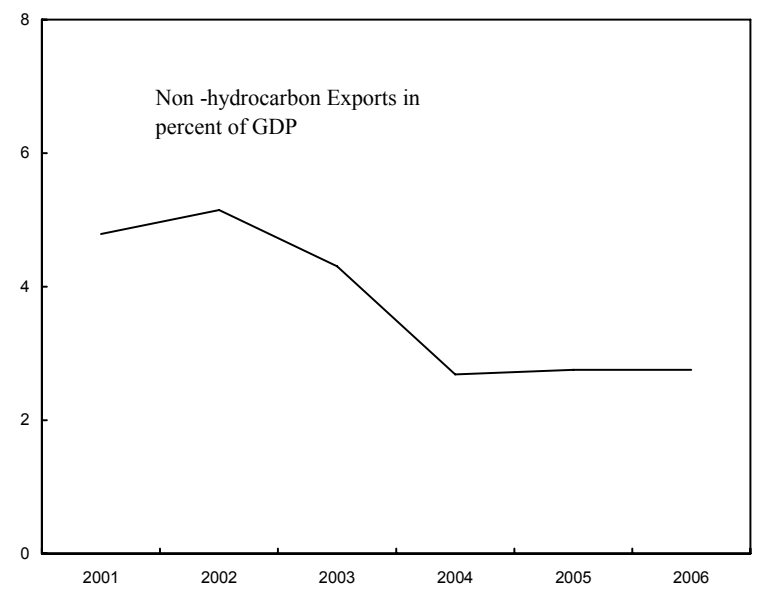

Yemen ranks poorly in competitiveness of the business environment ...

\begin{tabular}{|lrr|}
\hline & \multicolumn{2}{c|}{ Ranking out of 175 countries } \\
& 2005 & 2006 \\
Ease of: & & \\
Doing business & 101 & 98 \\
Starting a business & 169 & 171 \\
Employing workers & 52 & 53 \\
Getting credit & 117 & 117 \\
Paying taxes & 127 & 89 \\
& & \\
& & \\
\hline
\end{tabular}

Source: World Bank's Doing business database.
Most of Yemen's export prices are above international prices.

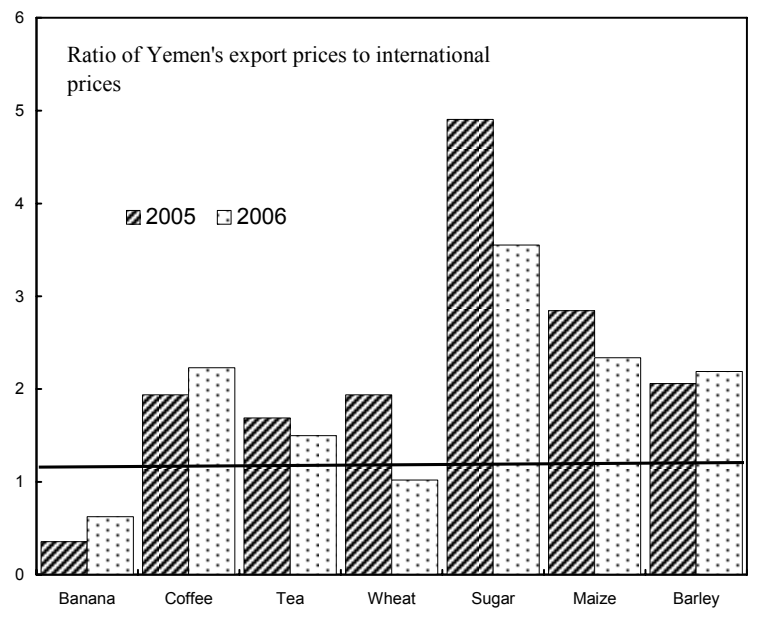

... while lagging behind MENA on some governance indicators. 1/

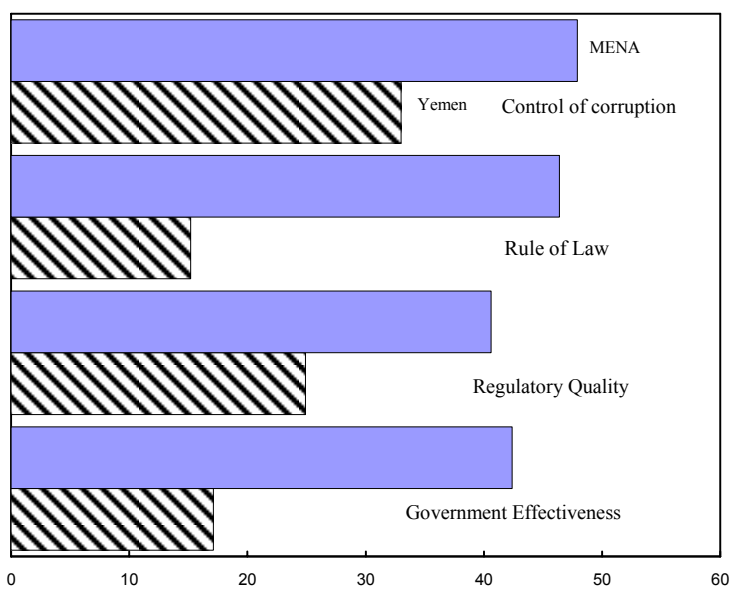

1/ Each entry shows percentile ranking out of over 200 countries in 2006. Source: World Bank's governance indicator database. 
11. The authorities were also hesitant to liberalize interest rates and pursue a more active interest rate policy. They fear that eliminating the minimum interest rate for rial deposits would reduce demand for rial holdings and put pressure on the rial. In staff's view, the minimum rate has effectively acted as a benchmark for all rates, and liberalizing interest rates, and allowing them to rise (until inflation is sufficiently reduced), combined with some nominal appreciation, could actually strengthen the incentive to de-dollarize.

\section{B. Medium-Term Policies: Ensuring Fiscal Sustainability}

12. While the authorities are placing high hopes on finding new oil and gas reserves, they agreed that fiscal policy needs to be based on conservative estimates of existing reserves (Box 3). Exploration activities have intensified and any major oil or gas finds could significantly change Yemen's outlook. Conservative estimates, shared by the authorities, of remaining recoverable hydrocarbon reserves, however, show that oil reserves could be depleted within some 10 years. A large liquefied natural gas (LNG) project will offer some compensation, but does not fundamentally alter the country's outlook. Oil revenues constituted three-fourths of government revenues in 2006, or almost 28 percent of GDP. Over the coming years, the budget will lose on average about 2 percentage points of GDP in hydrocarbon revenues each year.

13. The authorities acknowledged that current policies are not sustainable over the medium term and may lead to domestic and external instability. Staff presented a scenario of unchanged fiscal policies (Text Table 3). Under this scenario, the fiscal deficit would rise from less than 1 percent of GDP in 2006 to 20 percent of GDP by 2012. Assuming that these deficits could be financed, net public debt would rise from a manageable level of 31 percent of GDP to almost 75 percent of GDP over the same period, putting Yemen at a high risk of debt distress. An increasing part of the deficit would likely need to be financed by the CBY and inflation would accelerate. Growth would suffer. 


\section{Box 3. Hydrocarbon Sector Developments and Prospects}

Yemen is a small oil producer, but the country is highly dependent on developments in its oil and gas industry. Oil accounts for three-fourths of government revenue, and over 90 percent of export receipts. 60 percent of production is concentrated in two of the twelve producing blocks, Masila and Marib. As of end-2006, proven reserves (1p) amounted to 671 million barrels, while "probable and possible" $(2 p+3 p)$ reserves amounted to 883 million barrels. Assuming a 50 percent probability for the latter, remaining reserves would amount to some 1.1 billion barrels.

Official projections show a continuous decline in oil production. After peaking at 159 million barrels in 2000, production started to decline and fell to 130 million barrels in 2006. The slowdown is mostly associated with the maturing of the Masila and Marib fields. At current rates of production and reserve levels, proven reserves would be depleted by 2013. Adding 50 percent of probable and possible reserves, oil would run out by 2018. With growing domestic demand, Yemen would need to import petroleum products by 2015 , when demand would exceed the government share of oil production.

The production and export of liquefied natural gas will not fully offset the expected decline in oil production. The LNG project will produce and export 6.7 million tons of LNG, the equivalent of some 60 million barrels of oil per year, starting in 2009, for at least 20 years. The project has an estimated investment of around $\$ 4$ billion, entailing substantial imports of capital equipment during 2006-09.

Oil: Production projections, Government share, and domestic demand, millions of barrels per year

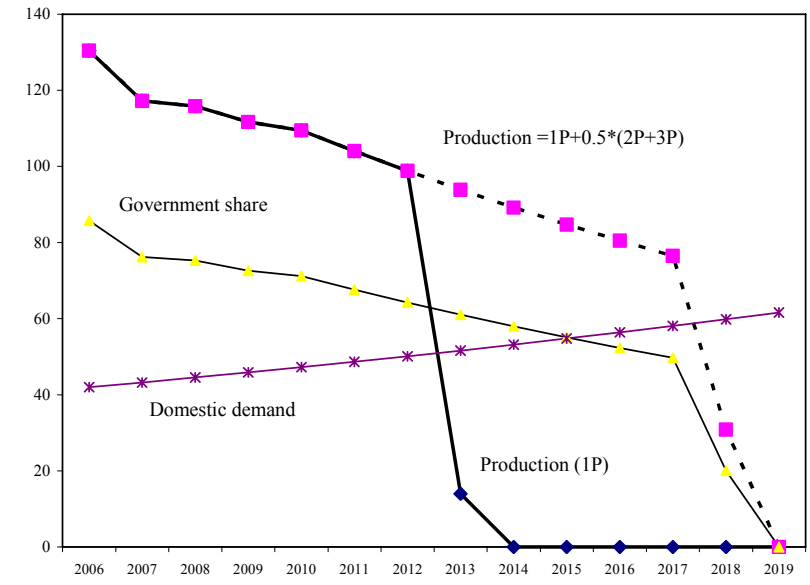

Oil operations in Yemen territory

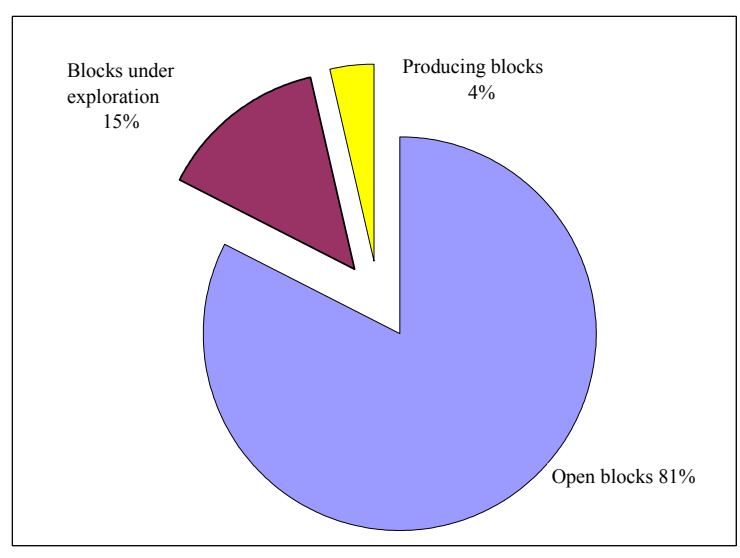

A major new find could significantly alter Yemen's outlook. Current oil producing fields comprise only 4 percent of Yemen's overall territory. An additional 15 percent (26 blocks) of Yemen's territory is currently under exploration, with more to follow. So far, exploration activities have not resulted in any major discovery, but most have just started. Meanwhile, the authorities and oil companies are aiming to improve the recovery ratio of existing fields. Based on current technologies, some 40 percent of the estimated oil in place could be economically recovered from the existing fields. While less dramatic, increasing this ratio could add a few years to Yemen's oil horizon. 
Text Table 3. Yemen: Unchanged Policies Scenario, 2005-12

\begin{tabular}{|c|c|c|c|c|c|c|c|c|}
\hline & 2005 & 2006 & 2007 & 2008 & 2009 & 2010 & 2011 & 2012 \\
\hline Fiscal & \multicolumn{8}{|c|}{ (In percent of GDP) } \\
\hline Total revenue and grants & 35.0 & 36.4 & 31.1 & 29.7 & 26.1 & 23.6 & 21.5 & 19.6 \\
\hline Hydrocarbon revenue & 26.3 & 27.5 & 22.5 & 21.3 & 17.7 & 15.2 & 13.2 & 11.4 \\
\hline Nonhydrocarbon revenue & 8.3 & 8.9 & 8.1 & 7.6 & 7.6 & 7.6 & 7.6 & 7.6 \\
\hline Nontax & 1.0 & 2.2 & 1.1 & 1.1 & 1.1 & 1.1 & 1.1 & 1.1 \\
\hline Grants & 0.4 & 0.0 & 0.5 & 0.8 & 0.8 & 0.7 & 0.7 & 0.6 \\
\hline Total expenditure (incl. net lending and discrepancy) & 35.3 & 36.6 & 36.2 & 37.8 & 37.3 & 37.7 & 38.8 & 40.1 \\
\hline Current expenditure & 26.9 & 27.0 & 27.2 & 28.1 & 27.4 & 27.8 & 28.9 & 30.3 \\
\hline of which: wages and salaries & 8.8 & 9.3 & 8.8 & 8.8 & 8.8 & 8.8 & 8.8 & 8.8 \\
\hline Interest obligations & 2.2 & 2.3 & 2.5 & 2.7 & 3.1 & 4.0 & 5.2 & 6.7 \\
\hline Subsidies and transfers & 12.0 & 11.1 & 11.8 & 12.5 & 11.4 & 10.9 & 10.8 & 10.6 \\
\hline of which: fuel & 8.7 & 7.7 & 8.1 & 8.8 & 7.7 & 7.2 & 7.0 & 6.9 \\
\hline Social welfare fund & 0.7 & 1.0 & 1.0 & 1.0 & 1.0 & 1.0 & 1.0 & 1.0 \\
\hline Capital expenditure & 7.9 & 7.3 & 7.5 & 8.0 & 8.3 & 8.2 & 8.3 & 8.2 \\
\hline Net lending & 2.0 & 1.3 & 1.6 & 1.6 & 1.6 & 1.6 & 1.6 & 1.6 \\
\hline Discrepancy & -1.5 & 1.0 & $\ldots$ & $\ldots$ & $\ldots$ & $\ldots$ & $\cdots$ & ... \\
\hline Overall balance (incl. discrepancy) & -0.3 & -0.2 & -5.2 & -8.1 & -11.2 & -14.1 & -17.4 & -20.5 \\
\hline Non-oil primary balance & -24.4 & -25.4 & -25.2 & -26.7 & -25.9 & -25.3 & -25.3 & -25.1 \\
\hline Net public debt & 37.1 & 31.4 & 33.7 & 38.5 & 41.9 & 51.0 & 61.6 & 73.7 \\
\hline Output and prices & \multicolumn{8}{|c|}{ (percentage change) } \\
\hline Overall real GDP & 4.6 & 4.0 & 3.6 & 4.0 & 7.1 & 3.9 & 2.3 & 1.9 \\
\hline Real hydrocarbon GDP & -0.8 & -8.3 & -10.1 & -1.2 & 39.7 & 7.0 & -3.2 & -3.1 \\
\hline Real nonhydrocarbon GDP & 5.3 & 5.7 & 5.2 & 4.5 & 4.0 & 3.5 & 3.0 & 2.5 \\
\hline Core inflation (end of period) & 20.2 & 22.0 & 14.0 & 18.0 & 22.0 & 25.0 & 28.0 & 31.0 \\
\hline External & \multicolumn{8}{|c|}{ (In percent of GDP) } \\
\hline Current account balance & 3.8 & 3.2 & -5.0 & -3.9 & -3.1 & -4.8 & -6.9 & -9.0 \\
\hline External debt & 30.8 & 27.3 & 26.3 & 25.4 & 23.7 & 24.8 & 27.3 & 30.4 \\
\hline
\end{tabular}

Sources: Yemeni authorities; and IMF staff estimates.

14. The authorities realized the need for a large fiscal adjustment effort. They agreed that the key for achieving sustainability lies in increasing non-oil revenues and a rationalization of government expenditures. Notably, fuel subsidies remain a big burden, taking up one-fifth of government spending. Staff also presented an adjustment scenario consistent with fiscal sustainability, aiming to keep the public debt-to-GDP ratio below 50 percent over the medium to long term. This implies that the non-oil primary deficit would need to be reduced on average by almost 2 percent of GDP per year for the coming years, limiting the overall deficit on average to 3-4 percent of GDP annually. Key measures include (i) the phased elimination of fuel subsidies in three years, accompanied by measures to safeguard the poor; (ii) a broadening of the tax base, including by eliminating tax exemptions, full implementation of the GST and increasing its rate from 5 to 10 percent, and introducing a fuel tax; (iii) civil service reform to contain the wage bill; and (iv) a streamlining of capital spending, while improving the quality of spending. Even with strong adjustment, vulnerabilities would remain, given the still relatively large overall fiscal deficits. 
15. The authorities broadly accepted the staff's adjustment scenario, but noted that implementation was likely to be slower due to political economy considerations. The authorities emphasized that while they intend to tackle the fuel subsidies in due course, they did not want to risk domestic instability, especially in light of the recent conflict in the north, the already high rates of inflation, and the weak social safety net. A fuel price increase in 2005 triggered strong and violent protests that resulted in considerable loss of life. The authorities could not give a specific time frame for fuel price increases. They have requested the World Bank to provide several scenarios for how to reduce the subsidies. Staff urged the authorities to start raising domestic fuel prices as soon as possible, and argued that the planned government wage increase could provide a good opportunity, but acknowledged that it should be done only in conjunction with improved targeting of the benefits provided by the Social Welfare Fund (SWF) and that part of the savings should be used to increase benefit levels and the number of beneficiaries. Work is currently underway to improve the targeting of the SWF, with technical assistance from the European Union. As part of this work, a revised law on social assistance will be submitted to parliament before end- 2007 .

16. Reforms aimed at increasing non-oil revenues by broadening the tax base and improving compliance are progressing, albeit slowly. The long-delayed GST is being implemented at 5 percent, but with concessions to overcome strong opposition from the powerful business community, which controls a number of key parliamentary committees. Full implementation will now start in 2009. The authorities also intend to reduce the corporate income tax rate from 35 percent to 20 percent later this year, to bring it more in line with neighboring countries, while simultaneously removing all existing exemptions in the income tax, customs, and investment laws, to avoid revenue losses. Because this also needs to pass the same parliamentary committees, there is a risk that at least some exemptions may remain. Efforts to modernize the tax administration, in line with FAD recommendations, to move to a self-assessment environment are continuing slowly, but are hampered by the generally poor state of record keeping by businesses.

17. The authorities have started an ambitious and comprehensive two-year public financial management reform program. This program has been developed with assistance from a group of donors. It aims to strengthen spending control, including by establishing a single treasury account, and to improve budget preparation, execution and reporting. In this regard, starting with the preparations for the 2008 budget, the authorities will cast their annual budget within an explicit medium-term macro framework and a three-year rolling MediumTerm Expenditure Framework.

\section{Medium-Term Policies: Promoting Sustained Nonhydrocarbon Growth}

18. As oil production declines, new sources of growth will need to be found, especially to absorb the rapidly growing labor force. While donor-financed projects will help boost non-oil growth in the coming years, the authorities are appropriately focusing on establishing an environment conducive to private investment as key to creating new employment opportunities and broadening the tax as well as the export base. In this context, a one-stop shop for new businesses will be established at the General Investment Authority. Continued reforms in the tax and customs administration, the new procurement legislation, and the creation of a 
national anticorruption authority will help address governance concerns. The authorities recently committed to join the Extractive Industries Transparency Initiative (EITI) with a view to further enhance transparency in the oil sector. The authorities also aim to improve the skill set of the relatively young Yemeni labor force by strengthening vocational training.

19. The authorities recognized that sustained growth also requires a much higher level of financial intermediation than currently exists in Yemen. By end-2006, credit to the private sector amounted to only 7 percent of GDP. Strong reforms will be needed to enhance financial intermediation, including the removal of the minimum interest rate for rial deposits (see above). Banks are also reluctant to lend because of weak mechanisms for contract enforcement, and typically lend only to well-known clients. As a result, high loan concentration ratios, as well as high levels of nonperforming loans, remain a concern (Text Table 4).

Measures are needed to strengthen property rights and contract enforcement, and create a transparent and effective judicial system. At the same time, banking supervision needs to be strengthened further, focusing also on the growing share of Islamic banks in Yemen's financial system. The authorities expressed interest in a Financial Sector Assessment update, to assess vulnerabilities and identify areas in need of further reform and assistance. Revisions to the Anti Money Laundering (AML) law, prepared with assistance of the UN, the World Bank, and the IMF are to be sent to parliament shortly.

Text Table 4. Yemen: Financial Soundness Indicators 1/

\begin{tabular}{|c|c|c|c|c|c|c|}
\hline & 2001 & 2002 & 2003 & 2004 & $\begin{array}{l}\text { Prel. } \\
2005\end{array}$ & $\begin{array}{c}\text { Prel. } \\
2006\end{array}$ \\
\hline & \multicolumn{6}{|c|}{ (In percent) } \\
\hline Regulatory capital to risk-weighted assets & 13.0 & 10.0 & 11.0 & 10.0 & 10.0 & 12.0 \\
\hline Capital (net worth) to assets & $\ldots$ & $\ldots$ & 5.0 & 5.0 & 5.0 & 6.5 \\
\hline Nonperforming loans to gross loans & 31.0 & 33.0 & 29.0 & 24.0 & 24.0 & 23.0 \\
\hline Nonperforming loans net of provisions to capital & 39.0 & 40.0 & 38.0 & 43.0 & 23.0 & 28.0 \\
\hline Return on assets & $\ldots$ & $\ldots$ & 0.8 & 0.8 & 1.1 & 1.2 \\
\hline Return on equity & $\ldots$ & $\ldots$ & 14.0 & 15.1 & 17.8 & 17.3 \\
\hline
\end{tabular}

Source: Central Bank of Yemen.

1/ Excludes Housing Credit Bank and Cooperative and Agricultural Credit Bank (CAC), except for 2006 data, which includes CAC Bank. 


\section{Data and Other Issues}

20. The authorities expressed strong interest in a multi-sector statistics mission to conduct a comprehensive evaluation of the macroeconomic statistics and develop a strategy for improving the quality and timeliness of data. Shortcomings complicating economic analysis are concentrated in the real sector (national account statistics, wages, and, to some extent, prices). Long delays in the availability of data are prevalent in almost all sectors. Staff also recommended that the authorities request a fiscal ROSC, with a view to increasing fiscal transparency, including an assessment of resource revenue issues as a useful complement to the EITI.

21. Yemen has a very open trade regime and is seeking to enhance trade integration. Most imports are subject to a 5 percent import tariff, while the highest rate is 25 percent. The Yemeni authorities hope to finalize discussions on accession to the World Trade Organization in the near future, pending further bilateral talks, and are also looking to strengthen linkages with the GCC countries.

\section{Staff Appraisal}

22. The Yemeni authorities face considerable challenges to promote strong economic growth to create new employment opportunities and reduce poverty, while ensuring fiscal and external sustainability in the context of declining oil reserves. Although the country's outlook could be significantly altered by the discovery of new oil and gas reserves, the authorities appropriately base their policies on existing hydrocarbon reserves.

23. The envisaged tightening of fiscal and monetary policies will help reduce inflation. Fiscal restraint is particularly important to avoid placing the entire burden to achieve single-digit inflation on monetary policy.

24. Monetary policy should focus more closely on achieving low inflation. Monetary targeting is hazardous, because of the economy's low monetization and high dollarization and conditions in Yemen are not suitable for formal inflation targeting. The CBY must therefore continue to rely to a considerable extent on the exchange rate as its nominal anchor. Swings in the country's equilibrium exchange rate brought about by oil price increases (in the short run) or by declining oil production (in the long run) may require that the exchange rate anchor be allowed to move up, or down, as needed to achieve low inflation, rather than always follow a (more or less) steady nominal depreciation.

25. To help bring down inflation more swiftly, the CBY could allow some nominal appreciation of the rial in the short run. The exchange rate appears to be slightly undervalued at the present time. In recent years, all of Yemen's real exchange rate appreciation was realized through higher inflation relative to its partner countries. It would be preferable for any real appreciation to become manifest in a stronger rial, rather than in inflation. A strengthening rial could also reduce the incentives to dollarize. Eventually, however, as oil production declines, a downward adjustment of the nominal exchange rate may be needed to bring about a depreciation of the real effective exchange rate so as to allow Yemen to become more competitive in the supply of nonhydrocarbon goods and services. 
26. The minimum interest rate for rial deposits should be removed to allow the CBY to conduct a more active interest rate policy and to enhance financial intermediation. Deepening financial markets will be essential for ensuring strong non-oil growth. Commercial bank credit operations would be enhanced by better contract enforcement, improved collateral arrangements, and strengthened property rights. Banking supervision and AML controls need to be strengthened as well and an FSAP update would help to assess potential risks and develop an agenda for financial sector reforms.

\section{Yemen's fiscal policies will need to adjust to the prospective decline in oil} production and revenues. Absent such an adjustment, Yemen would risk domestic and external instability. Although Yemen's relatively low debt burden and large foreign exchange reserves allow for some delays in the adjustment process, a more front-loaded effort than envisaged by the authorities would avoid the need for more abrupt changes later on. The most difficult and at the same time the most pressing measure is raising domestic fuel prices. This should go hand in hand with substantial improvements in the social safety net. Stronger efforts will also be needed to increase non-oil revenues - and especially to overcome opposition from the local business community to new tax measures - and to improve the quality and effectiveness of capital spending. Even with strong adjustment, Yemen will remain vulnerable to downside risks, including lower oil prices and slower non-oil growth.

\section{Yemen will need strong economic growth to achieve a significant reduction in} unemployment and poverty. At the moment, Yemen does not appear to be competitive in non-oil exports, which remain low. Productivity-enhancing reforms are urgently needed to enhance competitiveness, including further efforts to improve the investment climate and the quality of labor. Such reforms would need to encompass further actions to address governance concerns and red tape, including in tax and customs administration.

29. Data provision is still adequate for surveillance, but improvements are needed to better facilitate the formulation and monitoring of economic policies. Notably, real sector statistics should be a priority area for improvement, but further technical assistance will also continue to be needed in other areas to improve the quality and timeliness of data.

30. It is proposed that the next Article IV consultation discussions be held on the standard 12-month cycle. 
Table 1. Republic of Yemen: Selected Economic Indicators (Adjustment scenario), 2003-12

\begin{tabular}{|c|c|c|c|c|c|c|c|c|c|c|}
\hline & \multirow[b]{2}{*}{2003} & \multirow[b]{2}{*}{2004} & \multirow[b]{2}{*}{2005} & \multirow{2}{*}{$\begin{array}{l}\text { Prel. } \\
2006\end{array}$} & \multicolumn{6}{|c|}{ Projections } \\
\hline & & & & & 2007 & 2008 & 2009 & 2010 & 2011 & $\overline{2012}$ \\
\hline & & & & & hange in & ercent) & & & & \\
\hline \multicolumn{11}{|l|}{ Production and prices } \\
\hline Real GDP at market prices & 3.7 & 4.0 & 4.6 & 4.0 & 3.6 & 4.3 & 8.0 & 5.3 & 4.7 & 4.9 \\
\hline Real nonhydrocarbon GDP & 4.8 & 5.4 & 5.3 & 5.7 & 5.2 & 4.9 & 5.0 & 5.1 & 5.7 & 5.8 \\
\hline Real hydrocarbon GDP & -2.1 & -5.0 & -0.8 & -8.3 & -10.1 & -1.2 & 39.7 & 7.0 & -3.2 & -3.1 \\
\hline Consumer price index (annual average) & 10.8 & 12.5 & 11.7 & 18.2 & 12.5 & 12.1 & 10.5 & 9.5 & 8.8 & 8.3 \\
\hline Core consumer price index (annual average) 1/ & 11.9 & 12.0 & 14.5 & 20.3 & 14.0 & 11.5 & 10.5 & 9.5 & 8.8 & 8.3 \\
\hline Core consumer price index (12-month) $1 /$ & 12.1 & 14.5 & 20.2 & 22.0 & 12.0 & 11.0 & 10.0 & 9.0 & 8.5 & 8.0 \\
\hline Hydrocarbon production (1,000 barrels/day) & 425 & 396 & 393 & 357 & 321 & 316 & 443 & 474 & 459 & 444 \\
\hline Crude oil & 425 & 396 & 393 & 357 & 321 & 316 & 306 & 300 & 285 & 270 \\
\hline LNG (oil equivalent) & 0 & 0 & 0 & 0 & 0 & 0 & 137 & 174 & 174 & 174 \\
\hline \multirow[t]{2}{*}{ Crude export oil price (weighted average, U.S. dollar/barrel) 2/ } & 27.9 & 36.6 & 51.5 & 63.0 & 62.3 & 67.3 & 67.0 & 65.3 & 64.5 & 64.0 \\
\hline & \multicolumn{10}{|c|}{ (In percent of GDP) } \\
\hline \multicolumn{11}{|l|}{ Investment and savings } \\
\hline Consumption & 80.8 & 78.8 & 76.4 & 79.1 & 85.1 & 82.0 & 76.3 & 77.1 & 79.4 & 82.0 \\
\hline Government & 13.7 & 12.6 & 13.3 & 13.0 & 13.0 & 13.1 & 12.2 & 11.8 & 11.7 & 11.5 \\
\hline Other & 67.1 & 66.2 & 63.0 & 66.0 & 72.1 & 69.0 & 64.1 & 65.3 & 67.8 & 70.5 \\
\hline Gross domestic investment & 20.7 & 20.3 & 18.6 & 18.3 & 21.1 & 22.0 & 23.9 & 23.9 & 24.4 & 24.0 \\
\hline Government & 9.2 & 8.2 & 7.9 & 7.3 & 8.1 & 8.0 & 8.9 & 8.9 & 9.4 & 9.0 \\
\hline Other & 11.5 & 12.1 & 10.7 & 11.0 & 13.0 & 14.0 & 15.0 & 15.0 & 15.0 & 15.0 \\
\hline Gross national savings & 22.2 & 21.9 & 22.4 & 21.5 & 17.3 & 20.7 & 24.6 & 23.9 & 22.2 & 20.2 \\
\hline Government & 6.8 & 7.6 & 8.1 & 9.4 & 4.2 & 4.3 & 6.8 & 7.1 & 7.9 & 7.0 \\
\hline Other & 15.5 & 14.3 & 14.3 & 12.1 & 13.1 & 16.4 & 17.8 & 16.9 & 14.3 & 13.2 \\
\hline Savings-investment balance & 1.5 & 1.6 & 3.8 & 3.2 & -3.8 & -1.3 & 0.6 & 0.0 & -2.2 & -3.8 \\
\hline Government & -2.4 & -0.6 & 0.2 & 2.1 & -3.9 & -3.8 & -2.2 & -1.9 & -1.5 & -1.9 \\
\hline Other & 3.9 & 2.2 & 3.6 & 1.1 & 0.1 & 2.4 & 2.8 & 1.9 & -0.7 & -1.8 \\
\hline \multicolumn{11}{|l|}{ Government finance } \\
\hline Total revenue and grants & 31.1 & 32.0 & 35.0 & 36.4 & 30.9 & 30.7 & 30.2 & 28.9 & 27.8 & 26.6 \\
\hline Oil revenue & 22.2 & 22.6 & 26.3 & 27.5 & 22.3 & 20.8 & 18.0 & 16.4 & 14.9 & 13.5 \\
\hline Non-oil revenue & 8.5 & 8.7 & 8.3 & 8.9 & 8.2 & 8.7 & 11.2 & 11.5 & 11.8 & 12.0 \\
\hline Grants & 0.4 & 0.7 & 0.4 & 0.0 & 0.5 & 1.1 & 1.0 & 1.0 & 1.1 & 1.1 \\
\hline Total expenditure and net lending & 35.3 & 34.2 & 36.8 & 35.6 & 35.6 & 35.2 & 33.1 & 31.5 & 30.0 & 29.3 \\
\hline Current & 24.4 & 24.4 & 26.9 & 27.0 & 26.8 & 26.4 & 23.5 & 21.9 & 19.9 & 19.6 \\
\hline Development & 9.2 & 8.2 & 7.9 & 7.3 & 8.1 & 8.0 & 8.9 & 8.9 & 9.4 & 9.0 \\
\hline Net lending & 1.8 & 1.6 & 2.0 & 1.3 & 0.7 & 0.7 & 0.7 & 0.7 & 0.7 & 0.7 \\
\hline Overall balance (cash basis) $3 /$ & -5.3 & -1.7 & -0.3 & -0.2 & -4.6 & -4.5 & -2.9 & -2.6 & -2.2 & -2.7 \\
\hline Nonhydrocarbon primary fiscal balance (cash) $3 /$ & & & & & & & & & & \\
\hline In percent of nonhydrocarbon GDP & -36.9 & -32.1 & -37.9 & -38.2 & -33.9 & -31.1 & -27.6 & -24.3 & -21.1 & -19.3 \\
\hline In percent of GDP & -25.7 & -22.1 & -24.4 & -25.4 & -24.9 & -23.4 & -19.4 & -17.2 & -15.5 & -14.6 \\
\hline Gross Public Sector Debt & 56.8 & 52.1 & 43.8 & 38.9 & 38.9 & 40.0 & 36.2 & 36.7 & 36.0 & 37.3 \\
\hline & & & & $(12-r$ & nth chans & in percer & & & & \\
\hline Monetary data & & & & & & & & & & \\
\hline Broad money & 20.0 & 15.0 & 14.4 & 28.8 & 25.0 & $\ldots$ & $\ldots$ & $\ldots$ & $\ldots$ & $\ldots$ \\
\hline Credit to private sector & 26.3 & 33.5 & 21.3 & 16.7 & 12.5 & $\ldots$ & $\ldots$ & $\ldots$ & $\ldots$ & $\ldots$ \\
\hline Benchmark deposit interest rate (percent per annum) & 13.0 & 13.0 & 13.0 & 13.0 & & $\ldots$ & $\ldots$ & $\ldots$ & $\ldots$ & $\ldots$ \\
\hline Velocity (non-oil GDP/M2) & 2.1 & 2.1 & 2.1 & 2.3 & 2.1 & $\ldots$ & $\ldots$ & $\ldots$ & $\ldots$ & $\ldots$ \\
\hline & & & & & illions of $\mathrm{L}$ & S. dollars & & & & \\
\hline External sector & & & & & & & & & & \\
\hline Exports, f.o.b. & 3,924 & 4,676 & 6,413 & 7,285 & 6,377 & 6,740 & 7,688 & 7,760 & 7,334 & 6,895 \\
\hline Of which: hydrocarbon (oil and gas) & 3,417 & 4,303 & 5,952 & 6,733 & 5,814 & 6,144 & 7,056 & 7,089 & 6,617 & 6,128 \\
\hline Imports, f.o.b. & $-3,557$ & $-3,859$ & $-4,713$ & $-5,890$ & $-7,118$ & $-6,933$ & $-6,997$ & $-7,359$ & $-7,720$ & $-8,112$ \\
\hline Nonhydrocarbon imports & $-2,755$ & $-2,812$ & $-2,963$ & $-2,515$ & $-3,168$ & $-3,607$ & $-4,353$ & $-4,932$ & $-5,295$ & $-5,680$ \\
\hline Services and income balance (net) & $-1,571$ & $-2,036$ & $-2,473$ & $-2,115$ & $-1,594$ & $-1,864$ & $-2,284$ & $-2,288$ & $-2,357$ & $-2,237$ \\
\hline Current transfers (net) & 1,379 & 1,444 & 1,406 & 1,356 & 1,482 & 1,715 & 1,786 & 1,887 & 2,024 & 2,145 \\
\hline Current account & 176 & 225 & 633 & 636 & -853 & -343 & 192 & 0 & -719 & $-1,309$ \\
\hline Memorandum items: & & & & & & & & & & \\
\hline Central Bank own gross foreign reserves $4 /$ & 4,449 & 5,068 & 5,338 & 6,798 & 7,975 & 9,110 & 9,871 & 10,687 & 10,502 & 9,902 \\
\hline In months of imports 4 / & 15.2 & 15.0 & 11.0 & 10.8 & 12.6 & 14.4 & 14.8 & 15.0 & 14.0 & 13.2 \\
\hline Current account, incl. grants (in percent of GDP) & 1.5 & 1.6 & 3.8 & 3.2 & -3.8 & -1.3 & 0.6 & 0.0 & -2.2 & -3.8 \\
\hline Exchange rate (eop) (YRIs per U.S. dollar) & 184.3 & 185.8 & 195.1 & 198.5 & $\ldots$ & $\ldots$ & $\ldots$ & $\ldots$ & $\ldots$ & $\ldots$ \\
\hline Real effective exchange rate $(2000=100)$ & 111.2 & 115.8 & 120.2 & 132.1 & $\ldots$ & $\ldots$ & $\ldots$ & $\ldots$ & $\ldots$ & $\ldots$ \\
\hline Nominal GDP at market prices & & & & & & & & & & \\
\hline in billions of Yemeni rials & 2,161 & 2,563 & 3,207 & 3,944 & 4,297 & 4,909 & 6,065 & 6,922 & 7,700 & 8,563 \\
\hline in millions of U.S. dollars & 11,778 & 13,873 & 16,757 & 20,040 & $\ldots$ & $\ldots$ & $\ldots$ & $\ldots$ & $\ldots$ & $\ldots$ \\
\hline Per capita GDP (in U.S. dollars) & 598 & 682 & 799 & 927 & $\ldots$ & $\ldots$ & & $\ldots$ & $\ldots$ & \\
\hline Population (in thousands) & 19,702 & 20,329 & 20,975 & 21,622 & 22,290 & 22,978 & 23,687 & 24,398 & 25,130 & 25,884 \\
\hline
\end{tabular}

Sources: Yemeni authorities; and Fund staff estimates and projections.

$1 /$ Core CPI is defined as CPI excluding qat

2/ Oil price is different from the WEO price because Yemeni oil is traded at a discount.

3/ Includes statistical discrepancy.
/ Gross reserves minus commercial bank and pension fund foreign exchange deposits held with the Central Bank. 
Table 2. Republic of Yemen: General Government Finances (Adjustment Scenario), 2003-12 (In billions of Yemeni rials)

\begin{tabular}{|c|c|c|c|c|c|c|c|c|c|c|}
\hline & \multirow[b]{2}{*}{2003} & \multirow[b]{2}{*}{2004} & \multirow[b]{2}{*}{2005} & \multirow{2}{*}{$\begin{array}{l}\text { Prel. } \\
2006\end{array}$} & \multicolumn{6}{|c|}{ Projections } \\
\hline & & & & & 2007 & 2008 & 2009 & 2010 & 2011 & 2012 \\
\hline Total revenue and grants & 672 & 821 & 1,121 & 1,437 & 1,330 & 1,506 & 1,834 & 2,002 & 2,137 & 2,279 \\
\hline $\begin{array}{l}\text { Hydrocarbon revenue } \\
\text { of which: }\end{array}$ & 480 & 579 & 842 & 1,085 & 956 & 1,022 & 1,093 & 1,135 & 1,146 & 1,153 \\
\hline Crude oil exports & 307 & 361 & 482 & 638 & 484 & 498 & 471 & 457 & 413 & 365 \\
\hline LNG exports & 0 & 0 & 0 & 0 & 0 & 0 & 59 & 73 & 79 & 81 \\
\hline Nonhydrocarbon revenue & 184 & 223 & 265 & 351 & 352 & 427 & 682 & 799 & 908 & 1,030 \\
\hline Tax revenue & 153 & 187 & 235 & 266 & 305 & 374 & 616 & 723 & 823 & 937 \\
\hline Income taxes & 64 & 73 & 89 & 100 & 109 & 76 & 100 & 121 & 142 & 167 \\
\hline Taxes on goods and services & 43 & 56 & 89 & 112 & 132 & 224 & 422 & 489 & 552 & 622 \\
\hline Custom taxes & 42 & 52 & 52 & 36 & 45 & 52 & 67 & 83 & 96 & 111 \\
\hline Other taxes & 4 & 5 & 6 & 17 & 19 & 21 & 26 & 30 & 34 & 37 \\
\hline Non-tax & 31 & 36 & 31 & 85 & 47 & 54 & 66 & 76 & 84 & 94 \\
\hline Grants & 8 & 19 & 14 & 1 & 21 & 56 & 59 & 68 & 84 & 95 \\
\hline Total expenditure and net lending & 763 & 876 & 1,180 & 1,405 & 1,529 & 1,726 & 2,010 & 2,181 & 2,310 & 2,508 \\
\hline Current expenditure & 526 & 625 & 862 & 1,065 & 1,150 & 1,296 & 1,423 & 1,513 & 1,531 & 1,677 \\
\hline Wages and salaries & 202 & 227 & 281 & 365 & 387 & 444 & 490 & 537 & 584 & 632 \\
\hline Goods and services & 75 & 82 & 93 & 129 & 152 & 173 & 214 & 245 & 272 & 302 \\
\hline Operations and maintenance & 12 & 8 & 15 & 20 & 21 & 24 & 33 & 38 & 44 & 47 \\
\hline Interest obligations & 38 & 54 & 69 & 89 & 87 & 97 & 91 & 121 & 127 & 134 \\
\hline Domestic & 30 & 45 & 60 & 76 & 72 & 81 & 71 & 97 & 100 & 104 \\
\hline External & 7 & 9 & 9 & 13 & 15 & 16 & 20 & 24 & 27 & 30 \\
\hline Subsidies and transfers & 186 & 236 & 385 & 439 & 480 & 532 & 561 & 535 & 462 & 514 \\
\hline Subsidies & 111 & 152 & 286 & 309 & 327 & 313 & 254 & 157 & 11 & 12 \\
\hline Petroleum & 105 & 146 & 280 & 303 & 321 & 306 & 246 & 147 & 0 & 0 \\
\hline Electricity & 6 & 6 & 6 & 6 & 6 & 7 & 8 & 10 & 11 & 12 \\
\hline Transfers & 75 & 84 & 99 & 130 & 153 & 219 & 307 & 378 & 452 & 502 \\
\hline of which: Social Welfare Fund & 19 & 21 & 22 & 38 & 88 & 145 & 228 & 308 & 374 & 416 \\
\hline Other & 14 & 17 & 19 & 23 & 23 & 27 & 33 & 38 & 42 & 46 \\
\hline Capital expenditure & 198 & 211 & 254 & 289 & 347 & 394 & 543 & 618 & 722 & 769 \\
\hline of which: foreign financed & $\ldots$ & $\ldots$ & $\ldots$ & $\cdots$ & 57 & 91 & 108 & 121 & 170 & 180 \\
\hline Net lending & 38 & 41 & 63 & 51 & 32 & 36 & 45 & 51 & 57 & 63 \\
\hline Overall balan & -91 & -55 & -58 & 32 & -199 & -221 & -176 & -180 & -172 & -229 \\
\hline Pending obligations & 0 & 0 & 0 & 0 & 0 & 0 & 0 & 0 & 0 & 0 \\
\hline External interest paid & 10 & 0 & 0 & 0 & 0 & 0 & 0 & 0 & 0 & 0 \\
\hline Overall balance (cash) & -101 & -55 & -58 & 32 & -199 & -221 & -176 & -180 & -172 & -229 \\
\hline Financing & 114 & 43 & 10 & 7 & 199 & 221 & 176 & 180 & 172 & 229 \\
\hline External & 12 & 19 & 3 & 33 & 52 & 132 & 106 & 108 & 103 & 138 \\
\hline Domestic & 101 & 24 & 7 & -26 & 147 & 88 & 70 & 72 & 69 & 92 \\
\hline Discrepancy & -12 & 13 & 48 & -39 & 0 & 0 & 0 & 0 & 0 & 0 \\
\hline \multicolumn{11}{|l|}{ Memorandum items: } \\
\hline $\begin{array}{l}\text { Overall balance (cash) excluding } \\
\quad \text { foreign-financed capital expenditure 1/ }\end{array}$ & $\ldots$ & & & & -143 & -130 & -68 & -58 & -3 & -49 \\
\hline Primary balance (cash) $1 /$ & -76 & 11 & 59 & 82 & -112 & -124 & -85 & -59 & -45 & -95 \\
\hline Non-oil primary balance (cash) $1 /$ & -556 & -568 & -783 & $-1,003$ & $-1,069$ & $-1,147$ & $-1,179$ & $-1,193$ & $-1,191$ & $-1,248$ \\
\hline Non-oil primary balance (cash) excluding & & & & & & & & & & 068 \\
\hline $\begin{array}{l}\text { foreig } \\
\text { Defense }\end{array}$ & $\begin{array}{r}\cdots \\
137\end{array}$ & 136 & $\begin{array}{r}\ldots \\
156\end{array}$ & 162 & $\begin{array}{r}-1,012 \\
209\end{array}$ & $\begin{array}{r}-1,055 \\
239\end{array}$ & $\begin{array}{r}-1,071 \\
295\end{array}$ & $\begin{array}{r}-1,072 \\
337\end{array}$ & $\begin{array}{r}-1,021 \\
375\end{array}$ & $\begin{aligned} 1,068 \\
417\end{aligned}$ \\
\hline Social Spending 2/ & 185 & 218 & 233 & 276 & 348 & 442 & 594 & 727 & 839 & 934 \\
\hline Gross public debt $3 /$ & 1,228 & 1,335 & 1,405 & 1,535 & 1,671 & 1,963 & 2,197 & 2,541 & 2,776 & 3,193 \\
\hline Net public debt $3 /$ & 1,127 & 1,166 & 1,189 & 1,240 & 1,377 & 1,668 & 1,902 & 2,246 & 2,481 & 2,898 \\
\hline
\end{tabular}

Sources: Ministry of Finance; Ministry of Planning; and Fund staff estimates.

$1 /$ Includes statistical discrepancy (equivalent to below the line financing).

2/ Consists of education, health, social assistance and transfers to social welfare fund; covers central and local government units only.

3/ Refers to central and local governments. 
Table 3. Republic of Yemen: General Government Finances (Adjustment Scenario), 2003-12 (In percent of GDP)

\begin{tabular}{|c|c|c|c|c|c|c|c|c|c|c|}
\hline & \multirow[b]{2}{*}{2003} & \multirow[b]{2}{*}{2004} & \multirow[b]{2}{*}{2005} & \multirow{2}{*}{$\begin{array}{l}\text { Prel. } \\
2006\end{array}$} & \multicolumn{6}{|c|}{ Projections } \\
\hline & & & & & 2007 & 2008 & 2009 & 2010 & 2011 & 2012 \\
\hline Total revenue and grants & 31.1 & 32.0 & 35.0 & 36.4 & 30.9 & 30.7 & 30.2 & 28.9 & 27.8 & 26.6 \\
\hline $\begin{array}{l}\text { Hydrocarbon revenue } \\
\text { of which: }\end{array}$ & 22.2 & 22.6 & 26.3 & 27.5 & 22.3 & 20.8 & 18.0 & 16.4 & 14.9 & 13.5 \\
\hline Crude oil exports & 14.2 & 14.1 & 15.0 & 16.2 & 11.3 & 10.2 & 7.8 & 6.6 & 5.4 & 4.3 \\
\hline LNG exports & 0.0 & 0.0 & 0.0 & 0.0 & 0.0 & 0.0 & 1.0 & 1.0 & 1.0 & 0.9 \\
\hline Nonhydrocarbon revenue & 8.5 & 8.7 & 8.3 & 8.9 & 8.2 & 8.7 & 11.2 & 11.5 & 11.8 & 12.0 \\
\hline Tax revenue & 7.1 & 7.3 & 7.3 & 6.7 & 7.1 & 7.6 & 10.2 & 10.4 & 10.7 & 10.9 \\
\hline Income taxes & 2.9 & 2.9 & 2.8 & 2.5 & 2.5 & 1.5 & 1.6 & 1.7 & 1.8 & 1.9 \\
\hline Taxes on goods and services & 2.0 & 2.2 & 2.8 & 2.8 & 3.1 & 4.6 & 7.0 & 7.1 & 7.2 & 7.3 \\
\hline Custom taxes & 2.0 & 2.0 & 1.6 & 0.9 & 1.1 & 1.1 & 1.1 & 1.2 & 1.2 & 1.3 \\
\hline Other taxes & 0.2 & 0.2 & 0.2 & 0.4 & 0.4 & 0.4 & 0.4 & 0.4 & 0.4 & 0.4 \\
\hline Non-tax & 1.4 & 1.4 & 1.0 & 2.2 & 1.1 & 1.1 & 1.1 & 1.1 & 1.1 & 1.1 \\
\hline Grants & 0.4 & 0.7 & 0.4 & 0.0 & 0.5 & 1.1 & 1.0 & 1.0 & 1.1 & 1.1 \\
\hline Total expenditure and net lending & 35.3 & 34.2 & 36.8 & 35.6 & 35.6 & 35.2 & 33.1 & 31.5 & 30.0 & 29.3 \\
\hline Current expenditure & 24.4 & 24.4 & 26.9 & 27.0 & 26.8 & 26.4 & 23.5 & 21.9 & 19.9 & 19.6 \\
\hline Wages and salaries & 9.3 & 8.9 & 8.8 & 9.3 & 9.0 & 9.0 & 8.1 & 7.8 & 7.6 & 7.4 \\
\hline Goods and services & 3.5 & 3.2 & 2.9 & 3.3 & 3.5 & 3.5 & 3.5 & 3.5 & 3.5 & 3.5 \\
\hline Operations and maintenance & 0.6 & 0.3 & 0.5 & 0.5 & 0.5 & 0.5 & 0.5 & 0.5 & 0.6 & 0.6 \\
\hline Interest obligations & 1.8 & 2.1 & 2.2 & 2.3 & 2.0 & 2.0 & 1.5 & 1.7 & 1.7 & 1.6 \\
\hline Domestic & 1.4 & 1.7 & 1.9 & 1.9 & 1.7 & 1.6 & 1.2 & 1.4 & 1.3 & 1.2 \\
\hline External & 0.3 & 0.4 & 0.3 & 0.3 & 0.3 & 0.3 & 0.3 & 0.3 & 0.4 & 0.4 \\
\hline Subsidies and transfers & 8.6 & 9.2 & 12.0 & 11.1 & 11.2 & 10.8 & 9.3 & 7.7 & 6.0 & 6.0 \\
\hline Subsidies & 5.1 & 5.9 & 8.9 & 7.8 & 7.6 & 6.4 & 4.2 & 2.3 & 0.1 & 0.1 \\
\hline Petroleum & 4.8 & 5.7 & 8.7 & 7.7 & 7.5 & 6.2 & 4.1 & 2.1 & 0.0 & 0.0 \\
\hline Electricity & 0.3 & 0.2 & 0.2 & 0.1 & 0.1 & 0.1 & 0.1 & 0.1 & 0.1 & 0.1 \\
\hline Transfers & 3.5 & 3.3 & 3.1 & 3.3 & 3.6 & 4.5 & 5.1 & 5.5 & 5.9 & 5.9 \\
\hline of which: Social Welfare Fund & 0.9 & 0.8 & 0.7 & 1.0 & 2.1 & 3.0 & 3.8 & 4.5 & 4.9 & 4.9 \\
\hline Other & 0.6 & 0.7 & 0.6 & 0.6 & 0.5 & 0.5 & 0.5 & 0.5 & 0.5 & 0.5 \\
\hline Capital expenditure & 9.2 & 8.2 & 7.9 & 7.3 & 8.1 & 8.0 & 8.9 & 8.9 & 9.4 & 9.0 \\
\hline of which: foreign financed & $\ldots$ & $\ldots$ & $\ldots$ & $\ldots$ & 1.3 & 1.9 & 1.8 & 1.8 & 2.2 & 2.1 \\
\hline Net lending & 1.8 & 1.6 & 2.0 & 1.3 & 0.7 & 0.7 & 0.7 & 0.7 & 0.7 & 0.7 \\
\hline Overall balance (commitment) & -4.2 & -2.2 & -1.8 & 0.8 & -4.6 & -4.5 & -2.9 & -2.6 & -2.2 & -2.7 \\
\hline Pending obligations & 0.0 & 0.0 & 0.0 & 0.0 & 0.0 & 0.0 & 0.0 & 0.0 & 0.0 & 0.0 \\
\hline External interest paid & 0.5 & 0.0 & 0.0 & 0.0 & 0.0 & 0.0 & 0.0 & 0.0 & 0.0 & 0.0 \\
\hline Overall balance (cash) & -4.7 & -2.2 & -1.8 & 0.8 & -4.6 & -4.5 & -2.9 & -2.6 & -2.2 & -2.7 \\
\hline Financing & 5.3 & 1.7 & 0.3 & 0.2 & 4.6 & 4.5 & 2.9 & 2.6 & 2.2 & 2.7 \\
\hline External & 0.6 & 0.7 & 0.1 & 0.8 & 1.2 & 2.7 & 1.7 & 1.6 & 1.3 & 1.6 \\
\hline Domestic & 4.7 & 0.9 & 0.2 & -0.7 & 3.4 & 1.8 & 1.2 & 1.0 & 0.9 & 1.1 \\
\hline Discrepancy & -0.6 & 0.5 & 1.5 & -1.0 & 0.0 & 0.0 & 0.0 & 0.0 & 0.0 & 0.0 \\
\hline \multicolumn{11}{|l|}{ Memorandum items: } \\
\hline $\begin{array}{l}\text { Overall balance (cash) excluding } \\
\quad \text { foreign-financed capital expenditure } 1 /\end{array}$ & & & & & -3.3 & -2.6 & -1.1 & -0.8 & 0.0 & -0.6 \\
\hline Primary balance (cash) 1/ & -3.5 & 0.4 & 1.8 & 2.1 & -2.6 & -2.5 & -1.4 & -0.8 & -0.6 & -1.1 \\
\hline Non-oil primary balance (cash) 1/ & -25.7 & -22.1 & -24.4 & -25.4 & -24.9 & -23.4 & -19.4 & -17.2 & -15.5 & -14.6 \\
\hline Non-oil primary balance (cash) excluding & & & & & & & & & & \\
\hline foreign-financed capital expenditure $1 /$ & $\ldots$ & . & 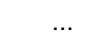 & $\ldots$ & -23.6 & -21.5 & -17.7 & -15.5 & -13.3 & -12.5 \\
\hline Defense spending & 6.4 & 5.3 & 4.9 & 4.1 & 4.9 & 4.9 & 4.9 & 4.9 & 4.9 & 4.9 \\
\hline Social Spending 2/ & 8.6 & 8.5 & 7.3 & 7.0 & 8.1 & 9.0 & 9.8 & 10.5 & 10.9 & 10.9 \\
\hline Gross public debt 3/ & 56.8 & 52.1 & 43.8 & 38.9 & 38.9 & 40.0 & 36.2 & 36.7 & 36.0 & 37.3 \\
\hline Net public debt $3 /$ & 52.2 & 45.5 & 37.1 & 31.4 & 32.0 & 34.0 & 31.4 & 32.4 & 32.2 & 33.8 \\
\hline
\end{tabular}

Sources: Ministry of Finance; Ministry of Planning; and Fund staff estimates

$1 /$ Includes statistical discrepancy (equivalent to below the line financing).

2/ Consists of education, health, social assistance and transfers to social welfare fund; covers central and local government units only.

$3 /$ Refers to central and local governments. 
Table 4. Republic of Yemen: Monetary Aggregates (Adjustment Scenario), 2000-07

\begin{tabular}{|c|c|c|c|c|c|c|c|c|}
\hline & 2000 & 2001 & 2002 & 2003 & 2004 & 2005 & 2006 & $\begin{array}{l}\text { Proj. } \\
2007\end{array}$ \\
\hline & \multicolumn{8}{|c|}{ (End of period stocks in billions of Yemeni rials) } \\
\hline Broad money (M2) & 474.5 & 563.0 & 664.7 & 797.4 & 917.3 & $1,049.5$ & $1,351.4$ & $1,689.3$ \\
\hline Money & 247.2 & 282.7 & 306.4 & 347.5 & 390.5 & 442.5 & 558.5 & 698.1 \\
\hline Currency & 197.1 & 212.8 & 239.3 & 268.8 & 297.9 & 330.6 & 412.5 & 515.6 \\
\hline Demand deposits & 50.1 & 69.9 & 67.1 & 78.7 & 92.6 & 111.8 & 145.9 & 182.4 \\
\hline Quasi-money & 81.1 & 96.3 & 139.1 & 179.4 & 239.5 & 251.5 & 338.8 & 423.5 \\
\hline Foreign currency deposits & 146.2 & 184.0 & 219.1 & 270.5 & 287.2 & 355.5 & 454.2 & 567.8 \\
\hline Net foreign assets & 487.3 & 652.1 & 838.2 & 971.5 & $1,117.6$ & $1,271.4$ & $1,675.1$ & $1,845.6$ \\
\hline Central bank (net) & 393.3 & 536.2 & 689.6 & 816.6 & 962.2 & $1,112.6$ & $1,419.2$ & $1,604.3$ \\
\hline Commercial banks (net) & 94.0 & 115.9 & 148.6 & 154.9 & 155.4 & 158.8 & 255.9 & 241.3 \\
\hline Net domestic assets & -12.8 & -89.0 & -173.6 & -174.1 & -200.3 & -221.9 & -323.6 & -156.4 \\
\hline Credit to government (net) & 3.9 & -46.0 & -71.8 & 12.1 & -7.9 & -34.9 & -88.8 & 43.9 \\
\hline Central bank (net) & -59.2 & -100.8 & -147.0 & -100.3 & -166.4 & -215.1 & -291.4 & -173.5 \\
\hline Commercial banks (net) & 63.1 & 54.8 & 75.2 & 112.4 & 158.5 & 180.1 & 202.6 & 217.4 \\
\hline Credit to nongovernment (net) & 73.6 & 82.2 & 61.8 & 80.5 & 126.6 & 167.5 & 206.3 & 224.5 \\
\hline Private sector & 75.7 & 95.3 & 108.9 & 137.6 & 183.6 & 222.6 & 259.9 & 292.4 \\
\hline Public enterprises & 0.0 & 0.0 & 0.3 & 0.3 & 0.0 & 0.0 & 3.1 & 3.5 \\
\hline Mixed enterprises & 0.5 & 0.7 & 0.8 & 1.0 & 1.9 & 3.1 & 6.2 & 7.0 \\
\hline Pension fund deposits & -2.6 & -3.6 & -47.6 & -57.7 & -56.9 & -57.8 & -62.3 & -77.9 \\
\hline Certificates of deposit & 0.0 & -10.1 & -0.6 & -0.7 & -2.1 & -0.6 & -0.5 & -0.5 \\
\hline \multirow[t]{2}{*}{ Other items (net) } & -90.3 & -125.2 & -163.6 & -266.7 & -319.0 & -354.4 & -441.1 & -424.7 \\
\hline & \multicolumn{8}{|c|}{ (Change in percent of initial M2) } \\
\hline Net foreign assets & 75.7 & 34.7 & 33.1 & 20.0 & 18.3 & 16.8 & 38.5 & 12.6 \\
\hline Net domestic assets & -50.6 & -16.1 & -15.0 & -0.1 & -3.3 & -2.3 & -9.7 & 12.4 \\
\hline Net credit to the government & -82.6 & -20.2 & -9.1 & 27.4 & -5.8 & -6.9 & -12.2 & 23.8 \\
\hline \multirow[t]{2}{*}{ Credit to private sector } & 3.5 & 4.1 & 2.4 & 4.3 & 5.8 & 4.3 & 3.6 & 2.4 \\
\hline & \multicolumn{8}{|c|}{ (12-month change in percent) } \\
\hline Broad money (M2) & 25.1 & 18.7 & 18.0 & 20.0 & 15.0 & 14.4 & 28.8 & 25.0 \\
\hline Of which: Rial broad money & 22.7 & 15.4 & 17.6 & 18.3 & 19.6 & 10.1 & 29.3 & 25.0 \\
\hline Credit to private sector & 21.3 & 25.8 & 14.3 & 26.3 & 33.5 & 21.3 & 16.7 & 12.5 \\
\hline \multicolumn{9}{|l|}{ Memorandum items: } \\
\hline Velocity of M2 (GDP/M2) & 3.8 & 3.4 & 3.2 & 3.0 & 3.0 & 3.3 & 3.4 & 2.8 \\
\hline Non-oil velocity (ratio non-oil GDP/M2) & 2.4 & 2.3 & 2.2 & 2.1 & 2.1 & 2.1 & 2.3 & 2.1 \\
\hline Credit to private sector/GDP & 4.9 & 5.7 & 5.8 & 6.4 & 7.2 & 6.9 & 6.6 & 6.8 \\
\hline Currency/deposits & 71.1 & 60.8 & 56.3 & 50.9 & 48.1 & 46.0 & 43.9 & 43.9 \\
\hline \multicolumn{9}{|l|}{ Dollarization (foreign currency deposits } \\
\hline Official gross reserves/reserve money & 197.6 & 237.9 & 266.0 & 257.0 & 255.6 & 245.9 & 262.4 & 235.3 \\
\hline
\end{tabular}

Sources: Central Bank of Yemen; and Fund staff estimates. 
Table 5. Republic of Yemen: Balance of Payments (Adjustment scenario), 2003-12 (In millions of U.S. dollars)

\begin{tabular}{|c|c|c|c|c|c|c|c|c|c|c|}
\hline & \multirow[b]{2}{*}{2003} & \multirow[b]{2}{*}{2004} & \multirow[b]{2}{*}{2005} & \multirow{2}{*}{$\begin{array}{c}\text { Prel. } \\
2006\end{array}$} & \multicolumn{6}{|c|}{ Projections } \\
\hline & & & & & 2007 & 2008 & 2009 & 2010 & 2011 & 2012 \\
\hline Current account & 176 & 225 & 633 & 636 & -853 & -343 & 192 & 0 & -719 & $-1,309$ \\
\hline Current account excl. hydrocarbon sector $1 /$ & $-2,066$ & $-2,614$ & $-3,118$ & $-2,659$ & $-3,038$ & $-3,572$ & $-4,168$ & $-4,537$ & $-4,906$ & $-5,149$ \\
\hline Goods and services & -177 & 127 & 840 & 515 & $-1,378$ & $-1,035$ & -79 & -332 & $-1,270$ & $-2,064$ \\
\hline Trade balance & 367 & 817 & 1,700 & 1,395 & -741 & -193 & 691 & 401 & -386 & $-1,217$ \\
\hline Exports, f.o.b. , of which: & 3,924 & 4,676 & 6,413 & 7,285 & 6,377 & 6,740 & 7,688 & 7,760 & 7,334 & 6,895 \\
\hline Hydrocarbon exports & 3,417 & 4,303 & 5,952 & 6,733 & 5,814 & 6,144 & 7,056 & 7,089 & 6,617 & 6,128 \\
\hline Nonhydrocarbon exports & 507 & 373 & 461 & 552 & 563 & 597 & 632 & 670 & 717 & 767 \\
\hline Imports, f.o.b., of which: & 3,557 & 3,859 & 4,713 & 5,890 & 7,118 & 6,933 & 6,997 & 7,359 & 7,720 & 8,112 \\
\hline Hydrocarbon sector imports & 803 & 1,046 & 1,750 & 3,375 & 3,950 & 3,326 & 2,644 & 2,427 & 2,425 & 2,432 \\
\hline Services, net & -544 & -690 & -860 & -881 & -637 & -842 & -769 & -732 & -884 & -847 \\
\hline Income, of which: & $-1,027$ & $-1,346$ & $-1,612$ & $-1,234$ & -957 & $-1,022$ & $-1,515$ & $-1,555$ & $-1,474$ & $-1,389$ \\
\hline Hydrocarbon company profits & -880 & $-1,130$ & $-1,535$ & $-1,370$ & $-1,132$ & $-1,222$ & $-1,728$ & $-1,798$ & $-1,713$ & $-1,603$ \\
\hline Current transfers, of which: & 1,379 & 1,444 & 1,406 & 1,356 & 1,482 & 1,715 & 1,786 & 1,887 & 2,024 & 2,145 \\
\hline General government's transfer, net & 149 & 171 & 154 & 113 & 110 & 290 & 290 & 315 & 362 & 387 \\
\hline Workers' remittances, net & 1,210 & 1,247 & 1,246 & 1,242 & 1,372 & 1,425 & 1,496 & 1,572 & 1,662 & 1,758 \\
\hline Capital \& financial account & 131 & 255 & -124 & 710 & 1,957 & 1,434 & 525 & 773 & 492 & 664 \\
\hline Direct investment, net, of which & 6 & 144 & -302 & 800 & 1,441 & 613 & -67 & -331 & -253 & -225 \\
\hline LNG sector & 0 & 0 & 0 & 1,200 & 1,785 & 975 & 110 & -199 & -199 & -203 \\
\hline Medium- and long-term loans, net & 68 & -51 & 63 & 200 & 523 & 808 & 579 & 1,086 & 727 & 872 \\
\hline Public and Publicly guranteed loans & 74 & 31 & 116 & 222 & 358 & 767 & 589 & 557 & 510 & 604 \\
\hline Other private capital, net & -5 & -82 & -53 & -23 & 164 & 41 & -10 & 529 & 217 & 268 \\
\hline Commercial banks, net & -10 & 5 & 22 & -475 & 0 & 19 & 19 & 19 & 19 & 19 \\
\hline Others, net & 67 & 158 & 93 & 185 & -8 & -6 & -6 & -2 & -2 & -2 \\
\hline Errors and omissions & 276 & 77 & -245 & 6 & 0 & 0 & 0 & 0 & 0 & 0 \\
\hline Overall balance & 583 & 556 & 264 & 1,353 & 1,104 & 1,092 & 717 & 773 & -228 & -644 \\
\hline \multicolumn{11}{|l|}{ Financing } \\
\hline Central Bank net foreign assets (- increase) & -583 & -679 & -452 & $-1,402$ & $-1,156$ & $-1,148$ & -775 & -830 & 171 & 585 \\
\hline Exceptional Financing & 0 & 123 & 189 & 49 & 52 & 57 & 57 & 57 & 57 & 60 \\
\hline Financing gap (+ deficit) & 0 & 0 & 0 & 0 & 0 & 0 & 0 & 0 & 0 & 0 \\
\hline \multicolumn{11}{|l|}{ Memorandum items: } \\
\hline Current account including grants (percent of GDP) & 1.5 & 1.6 & 3.8 & 3.2 & -3.8 & -1.3 & 0.6 & 0.0 & -2.2 & -3.8 \\
\hline Central bank own gross foreign reserves $2 /$ & 4,449 & 5,068 & 5,338 & 6,798 & 7,975 & 9,110 & 9,871 & 10,687 & 10,502 & 9,902 \\
\hline (months of imports) $3 /$ & 15.2 & 15.0 & 11.0 & 10.8 & 12.6 & 14.4 & 14.8 & 15.0 & 14.0 & 13.2 \\
\hline Total External Debt (percent of GDP) 4/ & 45.0 & 38.5 & 30.8 & 27.3 & 25.8 & 25.3 & 23.3 & 23.6 & 24.0 & 24.7 \\
\hline Export oil price (US\$/barrel) & 27.9 & 36.6 & 51.5 & 63.0 & 62.3 & 67.3 & 67.0 & 65.3 & 64.5 & 64.0 \\
\hline Nonhydrocarbon export (growth) & -7.9 & -26.5 & 23.8 & 19.7 & 2.0 & 6.0 & 6.0 & 6.0 & 7.0 & 7.0 \\
\hline Imports (growth) & 15.4 & 8.5 & 22.1 & 25.0 & 20.9 & -2.6 & 0.9 & 5.2 & 4.9 & 5.1 \\
\hline
\end{tabular}

Sources: Central Bank of Yemen; and Fund staff estimates and projections.

1/ Hydrocarbon sector includes oil and LNG exports less corresonding imports, expenses and repatriation.

2/ Includes central bank SDR holdings, foreign exchange held abroad, foreign securities, gold, silver and foreign currencies; excludes commercial

bank required foreign exchange reserves with the central bank against their foreign currency deposits and pension fund reserves.

3/ Imports are c.i.f. for next year and exclude oil sector imports. Include high grade oil imports for the refineries beginning 2005.

4/ Public and publicly guaranteed debt including central bank foreign liabilities. 
Table 6. Republic of Yemen: Millennium Development Goals, 1990-2005

\begin{tabular}{|c|c|c|c|c|c|c|c|c|}
\hline & 1990 & 1995 & 2000 & 2001 & 2002 & 2003 & 2004 & 2005 \\
\hline \multicolumn{9}{|l|}{ 1. Eradicate extreme poverty and hunger } \\
\hline Population below $\$ 1$ a day (percent) & $\ldots$ & $\ldots$ & $\ldots$ & $\ldots$ & $\ldots$ & 15.7 & $\ldots$ & $\ldots$ \\
\hline Poverty gap ratio at $\$ 1$ a day (percent) & $\ldots$ & $\ldots$ & $\ldots$ & $\ldots$ & $\ldots$ & $\ldots$ & $\ldots$ & $\ldots$ \\
\hline Percentage share of income or consumption held by poorest 20 percent & $\ldots$ & $\ldots$ & $\ldots$ & $\ldots$ & $\ldots$ & $\ldots$ & $\ldots$ & $\ldots$ \\
\hline Prevalence of child malnutrition (percent of children under 5 ) & $\ldots$ & $\ldots$ & $\ldots$ & $\ldots$ & $\ldots$ & 45.6 & $\ldots$ & $\ldots$ \\
\hline Population below minimum level of dietary energy consumption (percent) & $\ldots$ & $\ldots$ & 33.0 & $\ldots$ & $\ldots$ & 36.0 & $\ldots$ & $\ldots$ \\
\hline \multicolumn{9}{|l|}{ 2. Achieve universal primary education } \\
\hline Net primary enrollment ratio (percent of relevant age group) & 51.7 & $\ldots$ & 59.7 & 67.7 & 65.0 & 73.1 & 75.3 & $\ldots$ \\
\hline Percentage of cohort reaching grade 5 (percent) & $\ldots$ & $\ldots$ & 74.5 & 74.5 & 75.9 & 73.2 & $\ldots$ & $\ldots$ \\
\hline Youth literacy rate (percent ages $15-24$ ) & 50.0 & $\ldots$ & $\ldots$ & $\ldots$ & 67.9 & $\ldots$ & $\ldots$ & $\ldots$ \\
\hline \multicolumn{9}{|l|}{ 3. Promote gender equality } \\
\hline Ratio of girls to boys in primary education (percent) & 35.0 & $\ldots$ & 54.0 & 54.0 & $\ldots$ & 59.0 & 61.4 & \\
\hline Ratio of girls to boys in secondary education (percent) & $\ldots$ & $\ldots$ & 42.0 & $\ldots$ & $\ldots$ & 60.0 & $\ldots$ & $\ldots$ \\
\hline Women to men parity index, as ratio of literacy rates (percent ages $15-24$ ) & 34.0 & $\ldots$ & & $\ldots$ & 60.0 & $\ldots$ & $\ldots$ & $\ldots$ \\
\hline Share of women employed in the nonagricultural sector (percent) & 8.9 & 7.6 & 6.3 & $\ldots$ & 5.8 & 6.1 & $\ldots$ & $\ldots$ \\
\hline Proportion of seats held by women in national parliament (percent) & 4.0 & 1.0 & 1.0 & $\ldots$ & 1.0 & 0.3 & $\ldots$ & 0.3 \\
\hline \multicolumn{9}{|l|}{ 4. Reduce child mortality } \\
\hline Under 5 mortality rate (per 1,000$)$ & 142 & 126 & 117 & $\ldots$ & 114 & 113 & 113 & $\ldots$ \\
\hline Infant mortality rate $0-1$ year (per 1,000 live births) & 98 & 89 & 84 & $\ldots$ & 83 & $\ldots$ & $\ldots$ & 76.0 \\
\hline Immunization, measles (percent of children under 1 year old) & 69.0 & 46.0 & 71.0 & 79.0 & 65.0 & 66.0 & 76.0 & 76.0 \\
\hline \multicolumn{9}{|l|}{ 5. Improve maternal health } \\
\hline Maternal mortality ratio (per 100,000 live births) & 1,400 & 1,471 & 570 & $\ldots$ & $\ldots$ & $\ldots$ & $\ldots$ & $\ldots$ \\
\hline Births attended by skilled health staff & $\ldots$ & $\ldots$ & $\ldots$ & $\ldots$ & $\cdots$ & 26.8 & $\ldots$ & $\ldots$ \\
\hline \multicolumn{9}{|l|}{ 6. Combat HIVIAIDS, malaria and other diseases } \\
\hline Prevalence of HIV (percent ages 15-49) & $\ldots$ & $\ldots$ & $\ldots$ & $\ldots$ & $\ldots$ & 0.1 & 0.1 & $\ldots$ \\
\hline Contraceptive prevalence rate (percent of women ages 15-49) & $\ldots$ & $\ldots$ & $\ldots$ & $\ldots$ & $\ldots$ & 23.0 & 23.0 & $\ldots$ \\
\hline Number of children orphaned by HIVIAIDS & $\ldots$ & $\ldots$ & $\ldots$ & $\ldots$ & $\ldots$ & $\ldots$ & $\ldots$ & $\ldots$ \\
\hline Tuberculosis prevalence rate (per 100,000 people) & $\ldots$ & $\ldots$ & 102.0 & 99.0 & 95.0 & 91.0 & 86.0 & 82.0 \\
\hline Tuberculosis cases detected under DOTS (percent) & $\cdots$ & $\ldots$ & 56.0 & $\ldots$ & 49.0 & 43.3 & 43.3 & ... \\
\hline \multicolumn{9}{|l|}{ 7. Ensure environmental sustainability } \\
\hline Forest area (percent of total land area) & 1.0 & $\ldots$ & 0.9 & $\ldots$ & $\ldots$ & $\ldots$ & $\ldots$ & 1.0 \\
\hline Nationally protected areas (percent of total land area) & $\ldots$ & $\ldots$ & & $\ldots$ & $\ldots$ & $\ldots$ & $\ldots$ & $\ldots$ \\
\hline GDP per unit of energy use (PPP \$ per kg oil equivalent) & $\ldots$ & $\ldots$ & 2.9 & 2.7 & 2.9 & 3.0 & 2.8 & $\ldots$ \\
\hline $\mathrm{CO} 2$ emissions (metric tons per capita) & $\ldots$ & 0.7 & 0.5 & $\ldots$ & 0.7 & $\ldots$ & $\ldots$ & $\ldots$ \\
\hline Access to an improved water source (percent of population) & 69.0 & $\ldots$ & $\ldots$ & $\ldots$ & 69.0 & 69.0 & 67.0 & $\ldots$ \\
\hline Access to improved sanitation (percent of population) & 21.0 & $\ldots$ & $\ldots$ & $\ldots$ & 30.0 & 30.0 & 43.0 & $\ldots$ \\
\hline Access to secure tenure (percent of population) & $\ldots$ & $\ldots$ & $\ldots$ & $\ldots$ & $\ldots$ & $\ldots$ & $\ldots$ & $\ldots$ \\
\hline \multicolumn{9}{|l|}{ 8. Develop a global partnership for development } \\
\hline Youth unemployment rate (percent of total labor force ages 15-24) & $\ldots$ & $\ldots$ & $\ldots$ & $\ldots$ & $\ldots$ & $\ldots$ & $\ldots$ & $\ldots$ \\
\hline Fixed line and mobile telephones (per 100 people) & 1.1 & 1.3 & 2.1 & 2.0 & 7.6 & 10.2 & 14.8 & $\ldots$ \\
\hline Personal computers (per 100 people) & $\ldots$ & $\ldots$ & 0.2 & $\ldots$ & 0.7 & 0.7 & 0.8 & $\ldots$ \\
\hline \multicolumn{9}{|l|}{ General indicators } \\
\hline Adult literacy rate (percent of people ages 15 and over) & $\ldots$ & 40.0 & 46.0 & $\ldots$ & $\ldots$ & 49.0 & $\ldots$ & $\ldots$ \\
\hline Total fertility rate (births per woman) & $\ldots$ & 6.7 & 6.5 & $\ldots$ & 6.2 & 6.0 & $\ldots$ & 5.9 \\
\hline Life expectancy at birth (years) & $\ldots$ & 53.0 & 59.3 & $\ldots$ & 60.3 & $\ldots$ & $\ldots$ & 61.7 \\
\hline Aid per capita (current US\$) & $\ldots$ & $\ldots$ & 14.6 & 24.7 & 30.5 & 11.9 & 12.5 & 16.0 \\
\hline
\end{tabular}

Sources: World Bank; and Yemeni authorities. 

INTERNATIONAL MONETARY FUND

REPUBLIC OF YEMEN

Staff Report for the 2007 Article IV Consultation

Informational Annex

Prepared by Middle East and Central Asia Department

(in consultation with other departments)

August 17, 2007

Contents

Page

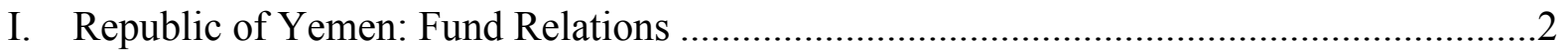

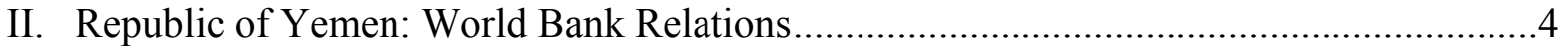

III. Republic of Yemen: Statistical Issues.........................................................................6

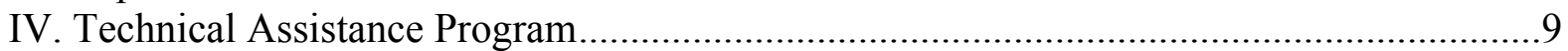




\section{ANNEX I. REPUBLIC OF YEMEN: FUND RELATIONS}

(As of July 31, 2007)

I. Membership Status: Joined May 22,1990 and has Article VIII status.

II. General Resources Account:

SDR Million

243.50

percent Quota

Quota

255.99

100.00

Fund holdings of currency

0.01

105.13

Reserve position

Holdings exchange rate

III. SDR Department:

SDR Million

Net cumulative allocation $\quad 28.74$

percent Allocation

28.74
2.63

100.00

Holdings

9.15

IV. Outstanding Purchases and Loans: SDR Million

Extended arrangements

12.50

Percent Quota

PRGF arrangements

120.28

5.13

49.39

V. Latest Financial Arrangements:

\begin{tabular}{|c|c|c|c|c|}
\hline Type & $\begin{array}{c}\text { Approval } \\
\text { Date } \\
\end{array}$ & $\begin{array}{l}\text { Expiration } \\
\text { Date } \\
\end{array}$ & $\begin{array}{c}\text { Amount Approved } \\
\text { (SDR million) } \\
\end{array}$ & $\begin{array}{l}\text { Amount Drawn } \\
\text { (SDR million) } \\
\end{array}$ \\
\hline $\mathrm{EFF}$ & $10 / 29 / 97$ & $10 / 28 / 01$ & 72.90 & 46.50 \\
\hline ESAF/PRGF & $10 / 29 / 97$ & $10 / 28 / 01$ & 264.75 & 238.75 \\
\hline Stand-By & $3 / 20 / 96$ & $6 / 19 / 97$ & 132.38 & 132.38 \\
\hline
\end{tabular}

VI. Projected Payments to Fund: ${ }^{12}$

\begin{tabular}{lrrrrr}
\hline & & \multicolumn{4}{c}{ Forthcoming } \\
& $\mathbf{2 0 0 7}$ & $\mathbf{2 0 0 8}$ & $\mathbf{2 0 0 9}$ & $\mathbf{2 0 1 0}$ & $\mathbf{2 0 1 1}$ \\
Principal & 25.69 & 45.20 & 28.38 & 17.75 & 15.75 \\
Charges/Interest & $\underline{1.18}$ & $\underline{1.85}$ & $\underline{1.42}$ & $\underline{1.26}$ & $\underline{1.17}$ \\
Total & 26.87 & 47.05 & 29.80 & 19.01 & 16.92 \\
\hline
\end{tabular}

\footnotetext{
${ }^{1}$ When a member has overdue financial obligations outstanding for more than three months, the amount of such arrears will be shown in this section.

${ }^{2}$ This schedule presents all currently scheduled payments to the IMF, including repayment expectations and repayment obligations. The IMF Executive Board can extend repayment expectations (within predetermined limits) upon request by the debtor country if its external payments position is not strong enough to meet the expectations without undue hardship or risk.
} 


\section{Safeguards Assessment:}

Under the Fund's safeguards assessment policy, the Central Bank of Yemen (CBY) was subject to the transitional procedures with respect to the EFF arrangement which expired on October 28, 2001. The assessment, which was completed on May 23, 2001, concluded that CBY's external audit mechanism was not fully adequate at the time, and recommendations were made to address the shortcomings. The CBY has submitted assessment letters and its audited financial statements up to 2006.

\section{Exchange Arrangements:}

The currency of Yemen is the Yemeni rial. The Yemeni authorities maintain that the current exchange rate system is a free float. However, staff are of the view that the exchange rate system is a facto crawling peg, in which the rate of crawl has recently slowed to resemble a conventional peg. Accordingly, under the IMF's classification, Yemen is currently considered a de facto conventional peg.

Yemen has accepted the obligations of Article VIII, Sections 2, 3, and 4, of the Articles of Agreement and maintains an exchange system that is free of multiple currency practices and restrictions on the making of payments and transfers for current international transactions. In accordance with UN Security Council Resolutions, Yemen has taken measures to block the accounts of certain individuals and organizations and has notified the Fund of these measures in accordance with Decision 144.

\section{Article IV Consultation:}

The latest Article IV consultation was concluded on June 2, 2006. Yemen is on the standard 12-month consultation cycle.

\section{X. $\quad$ FSAP Participation:}

FSAP (with the World Bank), October-November 2000.

\section{Technical Assistance:}

(See ANNEX IV)

\section{Resident Representatives:}

None. 


\section{ANNEX II. REPUBLIC OF YEMEN: WORLD BANK RELATIONS}

\section{A. Partnership in Yemen's Development Strategy}

1. Relations between the World Bank and the Government of Yemen are close and continue to cover knowledge and lending services in sectors critical to development and poverty reduction. The Bank's Board of Directors discussed the 2006-2009 Country Assistance Strategy (CAS) for Yemen in June 2006. This CAS was prepared after extensive consultations with central and local government officials, civil society, private sector and other donors. It also benefited from the Government's Progress Report for the first two years of implementation of the First Poverty Reduction Strategy Paper (2003-2005) as well as the 2006 Country Assistance Evaluation prepared by the Independent Evaluation Group of the World Bank.

2. The CAS is based on four pillars: (a) increasing non-oil growth; (b) improving human development outcomes; (c) improving fiscal sustainability; and (d) addressing the resource sustainability crisis. During the CAS period, IDA intends to provide about \$100 million annually in credits to Yemen through a selective program of lending operations complemented by a strategic program of analytical and learning services. Given the relatively limited amount of IDA resources available to Yemen, the Bank's larger contribution comes from its catalytic role in leveraging donors' resources, providing technical assistance to the Government and working with other donors to mainstream new implementation approaches that can enhance sectoral performance.

3. In mid-November 2006, the World Bank co-chaired with the Yemen's Government a Consultative Group (CG) meeting hosted by the UK Department of International Development, and sponsored by the Gulf Cooperation. The CG was attended by senior officials from 39 countries and international development agencies, and a total amount of US\$4.7 billion were pledged to finance Yemen's development for the four year period 2007-2010. The pledge represented over 85 percent of the Government's estimated external financing needs.

4. As part of the CAS, the International Finance Corporation (IFC), the private sector arm of the World Bank Group, is supporting the development of the private sector in Yemen through investments and technical assistance activities. The IFC focuses on enhancing competitiveness of the private sector, further deepening the financial sector, promoting investments in areas newly opened for private sector participation, encouraging sustainable social and environmental development, and promoting good corporate governance.

\section{B. Status of the World Bank Portfolio}

5. IDA. As of March 31, 2007, IDA had approved 136 projects for Yemen, valued at about US $\$ 2.3$ billion (excluding grants and cancellations), of which about US $\$ 2.0$ billion have been disbursed. The current portfolio has 18 active projects with a total net commitment of about US\$748 million, of which US\$447 million are undisbursed. The sectoral composition (by value) of the current portfolio is as follows: 50 percent for infrastructure projects, 17 percent for agriculture, 17 percent for education, 12 percent for health/social protection, and 4 percent for public sector governance. Over the last two years, portfolio performance has remained stabledisbursement ratio has so far reached 21 percent and is expected to rise to about 26 percent by the end of FY07. Out of 18 projects in the portfolio, only one project is rated problematic for issues 
on financial management. Recent actions taken, including project management changes, are expected to address the issues affecting that project.

6. IFC. In response to Government of Yemen's efforts in opening certain industries to private participation, IFC has recently increased its investment operations in the country with two relatively large investments in FY06, and has a strong pipeline in FY07, including Trade Finance lines for commercial banks. In FY06, IFC committed US\$60 million with two projects (US\$35 million in the HSA National Cement Company, a green-field cement plant and a US\$25 million investment in SOCO, an oil and gas project). In FY07, IFC already committed US\$20 million for the Saudi German Hospital and US\$10 million for a trade finance line with the Saba Islamic Bank. IFC is focusing on working with strong local private groups in Yemen, in particular, on the underdeveloped financial sector, banking, leasing, trade finance and selected industries.

7. Relation with the Multilateral Investment Guarantee Agency (MIGA): Currently, MIGA does not have any activities in Yemen. However, the ministry of planning and international cooperation has recently requested assistance to review its institutional framework for investment promotion. In response, FIAS/MIGA is planning a rapid diagnostic assessment of the overall investment promotion institutional arrangements in Yemen with a view to offering recommendations for the rationalization of roles, mandates and functions in this important strategic area of activity. 


\section{ANNEX III. REPUbLIC OF YEMEN: STATISTICAL ISSUES}

1. Delays in reporting and data weaknesses persist, and in some cases are getting worse; but data is still adequate to conduct surveillance. Due to shortcomings in most data, a broad effort is in place to improve data compilation with technical assistance from the Fund and other donors. In particular, national accounts data should be a priority for reform and improvement.

2. The Republic of Yemen has participated in the General Data Dissemination System (GDDS) since April 26, 2001. While some progress has been made, scope remains to improve the collection and dissemination of economic statistics, in line with Yemen's commitments under the GDDS.

3. The most reliable and timely data are those on the monetary sector produced by the Central Bank of Yemen (CBY). The CBY disseminates data on total official reserve assets and monetary statistics with a lag of one month. To strengthen monetary statistics further, a multisector mission in August 2000 recommended that: (a) repurchase agreements be treated as collateralized loans; (b) all nonstandard loans be reclassified as claims on the relevant sector; (c) counterparty for several monetary accounts be more accurately identified; and (d) a number of monetary accounts be disaggregated so as to present position on a single financial instrument. In June 2003, the authorities began reporting to STA a more disaggregated set of data that allowed for improved sectoral and instrument classification. Publication of the revised monetary statistics for December 1999 and onward, based on the more detailed data reporting, began in the August 2003 issue of IFS. In March 2007, with the availability of more detailed data, the definition of broad money was broadened to include the deposits of the pension funds, starting with data for December 1999. CBY does not yet report monetary data to STA using Standardized Report Forms (SRFs).

4. Although important progress has been achieved in terms of coverage, classification, and compilation methods of national accounts in accordance with the System of National Accounts 1993 (1993 SNA), significant work remains to be done to improve data quality and compilation methods. Based on technical assistance provided by STA and METAC in real sector statistics from September 2001 to November 2006, the Central Statistics Office (CSO) has compiled national accounts statistics for the years 1999-2005 that include: current accounts and the capital account by institutional sector; goods and services account and the integrated economic accounts for the total economy; and supply and use tables (SUT). The compilation of the SUT for 2004 is well underway. Most of the production and expenditure estimates are now based on direct methods that mainly use the results of recently conducted surveys, albeit with considerable lags. Quarterly establishment sample surveys to provide short-term indicators for moving annual benchmark series are underway and may be implemented in 2008. A household expenditure and income survey was conducted in 2005, and the results are expected to improve estimates of household final consumption and update the weights of the CPI. Additional work is needed to ensure the accuracy and the speed of collecting and processing survey results, to conduct new surveys in areas uncovered, to better identify the informal sector and the unorganized units and to update survey samples to improve coverage. There is also a need to develop short-term indicators for both current and constant prices, and to apply the 1993 SNA framework consistently for all published national accounts data. 
5. Regarding price statistics, some improvements have been made in the compilation of the consumer price index and the production of foreign trade price indices. METAC is currently assisting the CSO in developing a producer price index (PPI), however there has been no agreement on a specific action plan in this area. With the assistance of STA, the CSO has constructed a CPI that is consistent with international standards, with weights derived from the 1998 Households Budget Survey (HBS). The CPI has a broad geographic coverage and a sufficient number of consumption items, although some deficiencies remain in data collection practices. STA real sector missions have recommended further improving the sources of data in general, expanding the price statistics to cover different areas, and enhancing training and internal coordination within the CSO. CSO staff are currently working on updating the weights of the CPI basket to reflect the results of the $2005 \mathrm{HBS}$, and are considering reducing the number of commodities in the basket from the current coverage of 900 goods in the basket. To address problems in the field, the CSO has introduced a new framework to ensure consistency in data collection according to the following criteria: timing, good specifications, and location.

6. Fiscal data reliability and timeliness remain weak - particularly for detailed revenue, expenditure and financing items despite the provision of substantial technical assistance from several international agencies to improve the source data, the accounting and budgeting frameworks and information systems, and compilation methods. There are also discrepancies between reported budget data and below-the-line financing data obtained from the monetary statistics and CBY's BOP data. Fiscal data dissemination is limited to the hardcopy publication of the quarterly Bulletin of Government Finance Statistics (Bulletin), which provides annual, quarterly, and monthly data with significant lags. The authorities have not reported data for publication in the Government Finance Statistics Yearbook from 2000 onwards, and the latest data are estimates for 1999. No sub-annual data are reported for publication in International Financial Statistics. The GFS mission which visited Sana'a in January 2004 found that the available statistics, while disseminated with greater coverage and detail than previously, continued to suffer from numerous departures from international standards in classification and coverage. The mission encouraged the authorities to enhance the Bulletin of Government Finance Statistics with additional information on financing and on debt. The mission also recommended that the authorities expand their data dissemination by communicating the Bulletin, or the relevant data therein, to the IMF Statistics Department for re-dissemination and for the purpose of renewing the dialogue and remote technical assistance for the development of their GFS. Fiscal data based on the 2001 GFSM methodology have been compiled but have not been widely disseminated.

7. The CBY is responsible for compiling and disseminating balance of payments statistics, and more recently, the international investment position (IIP) statistics based on the IMF's Balance of Payments Manual, fifth edition. Compilation tasks are performed on a rather ad hoc basis, mostly relying on survey-based questionnaires with a response rate that is generally poor. The quality of the questionnaires themselves is also weak due to the limited expertise and experience in developing such material. Further compounding the weak quality of the statistics are inadequacies in documented sources and methods, and the limited financial and material resources dedicated to balance of payments compilation. The CBY publishes quarterly external debt statistics within one quarter of the reference period for the banking sector, general government, and monetary authority. Successive STA balance of payments statistics missions $(2002,2003$, and 2005) have sought to facilitate implementation 
of the action plan recommended by the IMF's resident advisor on balance of payments statistics (1998-2000), with only limited success. Coverage of the oil and gas industry transactions remains weak. Data questionnaires on FDI and selected items in services have either been discontinued or not followed up. The shortage of qualified staff dedicated to the compilation as well as weak coordination between the CBY and other government agencies (such as the customs authority, the CSO, and the ministry of oil and mining resources) are partly responsible for the slow progress.STA missions have consistently called for better coordination between the CBY and other government agencies for timely and effective data collection and compilation, improved staffing and training, and the reinstitution of discontinued surveys. A balance of payments mission in September 2005 found that the CBY had made some progress on increasing manpower and equipment in the balance of payments division, as well as training through the AMF. The mission also focused on the present method of estimating inward worker's remittances. Yemen has submitted quarterly balance of payments data to STA until end-2006, although the latest data published in the IFS and Balance of Payments Statistics Yearbook (BOPSY) relate to end-2005. Quarterly IIP data has also been supplied to STA for 2003 and 2004.

Table of Common Indicators Required for Surveillance

\begin{tabular}{|l|c|c|c|c|c|}
\hline & $\begin{array}{c}\text { Date of } \\
\text { Latest } \\
\text { Observation }\end{array}$ & $\begin{array}{c}\text { Date } \\
\text { Received }\end{array}$ & $\begin{array}{c}\text { Frequency } \\
\text { of } \\
\text { Data 6/ }\end{array}$ & $\begin{array}{c}\text { Frequency } \\
\text { of } \\
\text { Reporting 6/ }\end{array}$ & $\begin{array}{c}\text { Frequency } \\
\text { of } \\
\text { Publication 6/ }\end{array}$ \\
\hline Exchange rates & $5 / 31 / 07$ & $7 / 05 / 07$ & $\mathrm{D}$ & $\mathrm{D}$ & $\mathrm{D}$ \\
\hline $\begin{array}{l}\text { International reserve assets and reserve } \\
\text { liabilities of the monetary authorities 1/ }\end{array}$ & $5 / 31 / 07$ & $7 / 05 / 07$ & $\mathrm{M}$ & $\mathrm{M}$ & $\mathrm{A}$ \\
\hline Reserve/base money & $5 / 31 / 07$ & $7 / 05 / 07$ & $\mathrm{M}$ & $\mathrm{M}$ & $\mathrm{M}$ \\
\hline Broad money & $5 / 31 / 07$ & $7 / 05 / 07$ & $\mathrm{M}$ & $\mathrm{M}$ & $\mathrm{M}$ \\
\hline Central bank balance sheet & $5 / 31 / 07$ & $7 / 05 / 07$ & $\mathrm{M}$ & $\mathrm{M}$ & $\mathrm{M}$ \\
\hline $\begin{array}{l}\text { Consolidated balance sheet of the } \\
\text { banking system }\end{array}$ & $5 / 31 / 07$ & $7 / 05 / 07$ & $\mathrm{M}$ & $\mathrm{M}$ & $\mathrm{M}$ \\
\hline Interest rates 2/ & $5 / 31 / 07$ & $7 / 05 / 07$ & $\mathrm{M}$ & $\mathrm{M}$ & $\mathrm{M}$ \\
\hline Consumer price index & $5 / 31 / 2007$ & $7 / 05 / 07$ & $\mathrm{M}$ & $\mathrm{M}$ & $\mathrm{M}$ \\
\hline $\begin{array}{l}\text { Revenue, expenditure, balance and } \\
\text { composition of financing 3/-general } \\
\text { government 4/ }\end{array}$ & $12 / 31 / 06$ & $6 / 15 / 07$ & $\mathrm{M}$ & $\mathrm{I}$ & $\mathrm{Q}$ \\
\hline $\begin{array}{l}\text { Revenue, expenditure, balance and } \\
\text { composition of financing 3/-central } \\
\text { government }\end{array}$ & $12 / 31 / 06$ & $6 / 15 / 07$ & $\mathrm{M}$ & $\mathrm{I}$ & $\mathrm{Q}$ \\
\hline $\begin{array}{l}\text { Stocks of central government and } \\
\text { central government-guaranteed debt 5/ }\end{array}$ & $12 / 31 / 06$ & $6 / 15 / 07$ & $\mathrm{M}$ & $\mathrm{M}$ & $\mathrm{M}$ \\
\hline External current account balance & $12 / 31 / 06$ & $6 / 15 / 07$ & $\mathrm{~A}$ & $\mathrm{~A}$ & $\mathrm{~A}$ \\
\hline
\end{tabular}




\begin{tabular}{|l|c|c|c|c|c|}
\hline $\begin{array}{l}\text { Exports and imports of goods and } \\
\text { services }\end{array}$ & $12 / 31 / 06$ & $6 / 15 / 07$ & $\mathrm{~A}$ & $\mathrm{~A}$ & $\mathrm{~A}$ \\
\hline GDP/GNP & 2006 & $6 / 15 / 07$ & $\mathrm{~A}$ & $\mathrm{~A}$ & $\mathrm{~A}$ \\
\hline Gross external debt & $12 / 31 / 06$ & $6 / 15 / 07$ & $\mathrm{Q}$ & $\mathrm{Q}$ & $\mathrm{Q}$ \\
\hline
\end{tabular}

1/ Includes reserve assets pledged or otherwise encumbered as well as net derivative positions.

2/ Both market-based and officially-determined, including discount rates, money market rates, rates on treasury bills, notes and bonds.

3/ Foreign, domestic bank, and domestic nonbank financing.

4/ The general government consists of the central government (budgetary funds, extra budgetary funds, and social security funds) and state and local governments.

$5 /$ Including currency and maturity composition.

6/ Daily (D), Weekly (W), Monthly (M), Quarterly (Q), Annually (A), Irregular (I); Not Available (NA).

\section{Annex IV. Technical Assistance Program ${ }^{3}$}

\section{a. IMF}

FAD_Pension Reform, August 2001

FAD — Reform of the Budgetary Process, April 2002

FAD_Public expenditure management expert installation, September 2002

FAD - Tax policy, tax administration and customs reform, October-November 2002

FAD — Public Expenditure Management Advisor, August 2003-January 2004

FAD_Public Expenditure Management, March-April 2004

FAD-Support to LTO, April 2005

FAD_GST Implementation, April 2005

FAD — Support to LTO and GST Implementation, November 2005

FAD_Reforming Tax Administration and implementing GST, June 2006

FAD—Treasury Function and Related PFM Reforms, July 2007

MAE_-Foreign reserves management, February-March 2001

MAE - Technical Assistance and Training Coordination and Expenditure Resource Mobilization, March 2005

MAE - ST Regional Expert Assignment, June-July 2005

MAE - ST Regional Expert Assignment, August 2005

MAE - Support for the regulatory framework of the Central Bank of Yemen, September-October 2005

MFD_Liquidity Management, March-April 2005

MFD_Regional Advisor, September 2005

MFD_-Payment Systems and Monetary Operations, October 2005

MFD - Support for the Central Bank of Yemen credit Registry, November-

December 2005

\section{OTM-TCAP Review, March 2004}

\footnotetext{
${ }^{3}$ Mission; unless otherwise indicated.
} 
OTM-Yemen - TCAP, March-April 2004

OTM-METAC - Needs Assessment Mission, February 2005

STA-Balance of payments statistics, January 2003

STA - Government Finance Statistics, January 2004

STA-National Accounts Statistics, January 2004

STA-National Accounts Statistics, May-June 2004

STA-Balance of payments statistics, September 2005

LEG-AML/CFT Diagnostic, May 2006

LEG-AML/CFT Legal Drafting, November 2006

b. UNDP/IMF/DFID Program:

FAD — LTE on budget management, March 1998-June 2001, and

September 2002-January 2004

MAE - LTE on bank supervision, May 1997-May 2001

MED_L LTE on debt management, July 1997-March 2001

STA-LTE on balance of payments statistics, February 1998-February 2000

FAD_Peripatetic experts on customs reform, July 1999-July 2001

STA-Peripatetic expert on national accounts, September 2001-August 2002

MAE-Peripatetic expert on foreign reserves management since April 2002

c. IMF/World Bank Program:

MAE-FSAP, October-November 2000

FAD_AFMIS Inspection Mission, September-October 2004 


\title{
INTERNATIONAL MONETARY FUND
}

\section{REPUBLIC OF YEMEN}

\section{Joint World Bank/IMF Debt Sustainability Analysis}

\author{
Prepared by the Staff of the International Monetary Fund and \\ the International Development Association
}

Approved by Adam Bennett and Adnan Mazarei (IMF) and Mustapha Nabli and Vikram Nehru (IDA)

August 30, 2007

\section{INTRODUCTION}

\section{This Debt SustainabilityAnalysis (DSA) finds Yemen to face a high risk of (external)} debt distress. The probability of debt distress is particularly high if the authorities do not embark upon a major fiscal adjustment effort in light of the dwindling oil reserves, even though debt levels are currently still manageable. With unchanged policies, debt ratios would rapidly deteriorate and exceed thresholds within a few years. But even under the baseline scenario that assumes full implementation of a comprehensive set of fiscal and structural reforms (Box 1), debt thresholds would be either approached within the DSA horizon (Net Present Value (NPV) of external debt-toGDP ratio) or breached (NPV of external debt-to-exports ratio). This is amplified in the standard DSA stress tests (and also under an additional stress test that simulates a lower oil price), especially if financing would only be available on moderately concessional terms. In other words, if Yemen is to avoid debt distress, this will require strong fiscal and structural reforms, as well as highly concessional financing.

\section{METHODOLOGY}

2. The DSA uses the debt sustainability framework for low-income countries (www.imf.org). Debt sustainability is assessed in relation to policy-dependent debt burden thresholds. According to the average Country Policy and Institutional Assessment (CPIA) index over 2004-06, Yemen is classified as a medium performer in terms of its policies and institutions. ${ }^{1}$

3. The DSA is based on the staff's adjustment (baseline) and nonadjustment scenarios. The adjustment scenario assumes full implementation of fiscal reforms over the medium term (2007-12), which are assumed to be continued and intensified as Yemen's oil reserves run out by 2018. The nonadjustment scenario assumes the absence of fiscal adjustment, as reflected by a broadly unchanged non-oil primary balance. Both scenarios are based on identical conservative estimates of

\footnotetext{
${ }^{1}$ For a medium performer, the indicative thresholds for external debt sustainability are an NPV of debt-to-export ratio of 150 percent, an NPV of debt-to-GDP ratio of 40 percent, an NPV of debt-to-revenue ratio of 250 percent, a debt service-to-exports ratio of 20 percent, and a debt service-to-revenue ratio of 30 percent.
} 
proven oil and gas reserves. Since the nonadjustment scenario is clearly unsustainable, stress tests are applied to the adjustment scenario to assess whether any vulnerabilities would remain when the authorities implement a strong package of reforms. In discussions with the Yemeni authorities, they broadly accepted the adjustment scenario as the way forward, but noted that implementation was likely to be delayed due to political economy considerations.

\section{BACKGROUND}

4. This DSA updates the previous DSA by allowing for more informed estimates of government revenues from the Liquefied Natural Gas (LNG) project and LNG export receipts, use of actual 2006 debt data for both public and external debt, estimates of new disbursements as pledged in the 2006 Consultative Group (CG) meeting in London, and resolution of some bilateral debt issues since then. In particular, debt to India will be paid in full as a lump sum. Debt to Hungary has been fully paid. Debt to Iraq is being serviced on schedule following an agreement reached with the Iraqi authorities. Agreements still have to be reached with China, Kuwait, and the Arab Fund for Social and Economic Development. In addition, Yemen may benefit substantially from future grants from the Millennium Challenge Corporation, pending progress in its reforms.

\section{The Current Situation}

5. Yemen's total external public debt, based on data from the debt unit of the Central Bank of Yemen (CBY), stood at \$5,469 million (27.3 percent of GDP) by end 2006, an increase of $\$ 300$ million over end-2005, which was mostly due to new IDA borrowings (Table 1). Debt to IDA accounts for about 35 percent of Yemen's external debt and some 67 percent of multilateral debt. Among Yemen's bilateral creditors, the Russian Federation is the largest (32 percent of total external debt), followed by Kuwait and Saudi Arabia (6 percent each). Yemen benefited from a series of rescheduling arrangements under the Paris Club in 1996, 1997, and 2001.

Table 1. Republic of Yemen: Stock of Government Debt at end-2006

\begin{tabular}{lrr}
\hline & Millions of dollars & Percent of total \\
\hline 1. Domestic debt & 2,264 & 29 \\
Banks & 1,038 & 13 \\
Non-banks & 1,226 & 16 \\
& & \\
2. External debt & 5,469 & 71 \\
Multilaterals & 2,780 & 36 \\
Bilateral & 2,689 & 35 \\
$\quad$ Paris club & 1,729 & 22 \\
$\quad$ Non-Paris club & 960 & 12 \\
& & 100 \\
Total debt (=1+2) & 7,733 & \\
\hline
\end{tabular}

Source: Central Bank of Yemen

6. Yemen's stock of gross domestic public debt stood at about 11 percent of GDP at end-2006, consisting primarily of T-bills of various maturities held by nonbanks (two-thirds) and banks (one-third). Net domestic debt (net of government deposits) was 4 percent of GDP at end-2006, resulting in a total net public debt stock of 31.4 percent (38.9 percent gross) at end-2006. 


\section{Box 1. Macroeconomic Assumptions for the Adjustment Scenario}

Yemen is highly dependent on oil. In 2006, oil receipts accounted for 74 percent of fiscal revenues and 92 percent of merchandise export revenues. By 2018, when Yemen is expected to run out of oil, hydrocarbon revenues (from LNG exports and the domestic sale of gas) are projected to decline to 30 percent of total government revenues and export receipts to 54 percent of total exports. The current high dependence is not sustainable. Maintaining fiscal sustainability is therefore an important concern underlying the adjustment scenario.

In the medium term, the key spending reforms include an elimination of fuel subsidies by end-2010; containment of the civil service wage bill and defense spending; better expenditure control and management, as well as increases in social spending; and better targeting to protect the poor of the adverse effects of removal of fuel subsidies and taxes on petroleum products. Significant revenue reforms include full implementation of the General Sales Tax (doubling in 2009 to 10 percent from 5 percent); stepped-up reform of customs and tax administration, rationalization or elimination of exemptions in the customs, income tax, and investment laws; and imposition of a tax on petroleum products as fuel subsidies are phased out. The combined impact of tax policy and tax administration measures is assumed to increase tax revenues from $6 \frac{1}{2}$ percent of GDP in 2006 to 11 percent in 2012. Average real GDP growth for this period is projected at 5 percent; the average fiscal deficit at $3 \frac{1}{3}$ percent; and the average current account deficit at 2 percent of GDP. Oil prices are based on the most recent WEO projections.

For the longer term, the following assumptions were made:

- $\quad$ Overall real GDP growth will remain moderate, averaging 4 percent during 2013-27, with a nonhydrocarbon growth of about 5 percent maintained through 2017 (through development of tourism, manufactures, and fishing, and large public investment projects financed by CG money). The GDP growth assumption is well within the bounds of historical experience (the average growth rate over 1997-2006 was 4.5 percent, Table 2), and consistent with the reforms and adjustment envisioned in the adjustment scenario-with the bulk of such reforms implemented over the medium term (2007-12) — and projected external assistance. The baseline scenario projects nonhydrocarbon growth (which will be the driving force after oil reserves are depleted) to average 4 percent over the long term. By comparison, average nonhydrocarbon growth during 1991-2005 was 5.2 percent, and during the reform years (1995-2001) was close to 6 percent.

- $\quad$ The current account balance falls into sizeable deficits with the depletion of oil, but recovers somewhat over the long term, reflecting a steady pick-up in non-oil exports (but which start from a low base).

- Most of the new revenue mobilization efforts are expected to be put in place over the medium term. Beyond 2012, revenue enhancement has to be gained from further improvements in the efficiency of indirect tax collection (GST, customs duties, excises on petroleum products), income taxes, as well as a further increase in the GST rate to 13 percent, accompanied with a further strengthening of the tax and customs administration through 2018. For the adjustment to be permanent and sustainable, these gains need to be maintained and accompanied by further containment of public sector spending, as the private sector is increasingly taking a larger role in the economy. Tax revenues are expected to reach 16 percent of GDP by 2027

- $\quad$ Future external borrowings are assumed to come from official creditors at concessional terms. Domestic borrowing is driven by the evolution of the government's fiscal balance, and is assumed to come from the bank and nonbank sector (including the pension fund) at positive real interest rates. 


\section{Public Debt Sustainability}

7. Under unchanged policies, all three indicators show public debt to be unsustainable in the medium term and to worsen markedly over time.

8. Under the adjustment scenario, all three indicators increase over time. The NPV of (net) public debt-to-GDP ratio rises markedly from 271/2 percent of GDP at end-2006 to $31 \frac{1}{2}$ percent in 2017, as the country runs out of oil, and rises further thereafter to a level of 43 percent in 2027. In book value terms, the rise is more pronounced, with the (net) public debt-to-GDP ratio rising from $31 \frac{1}{2}$ percent of GDP in 2006 to 34 percent in 2017, accelerating to 47 percent in 2027, despite expenditure cuts and consolidation of revenue gains.

9. Stress tests show that, under an adjustment scenario, Yemen remains vulnerable to shocks and to lapses in commitment to implementation of fiscal and structural measures to accelerate fiscal adjustment and growth, particularly in the non-oil economy. Adverse shocks (including an oil price shock developed specifically for this DSA) have quick and sizeable effects on all three debt indicators and become more pronounced as Yemen runs out of oil. Yemen is particularly sensitive to adverse oil price shocks as growth of nonhydrocarbon revenues and nonhydrocarbon export receipts are too slow to enhance its debt capacity repayment.

\section{External DebT Sustainability}

10. Under the nonadjustment scenario, debt thresholds for the NPV of debt-to-GDP ratio and the NPV of debt-to-export ratio are permanently breached by $\mathbf{2 0 1 2}$. The threshold for the debt-service-to-exports ratio is permanently breached by 2018 .

11. Under the adjustment scenario, the NPV of external debt-to-GDP ratio increases steadily and stabilizes at about 30 percent, but the breach of the threshold for the NPV of debt to exports is sustained within the DSA horizon. Stress tests such as borrowings on less favorable terms and an oil price shock can quickly translate into debt levels that exceed the threshold, and which worsen further as Yemen runs out of oil. Two out of three indicators (NPV of debt-to-exports and NPV of debt service-to-exports ratio) show protracted breaches of debt thresholds beyond 2018, highlighting the need to accelerate the pace of nonhydrocarbon export growth well before Yemen runs out of oil.

12. Under the adjustment scenario, the debt service-to-export ratio remains below the threshold of 20 percent. However, as with other indicators, it worsens as Yemen runs out of oil reserves, increasing from 71/2 percent in 2017 to 11 percent in 2018 and 14 percent in 2027. Under stress testing, the threshold is breached in outer years, particularly under an adverse oil price shock. 
Figure 1.Yemen: Indicators of Public Debt Under Alternative Scenarios, 2007-2027 1/

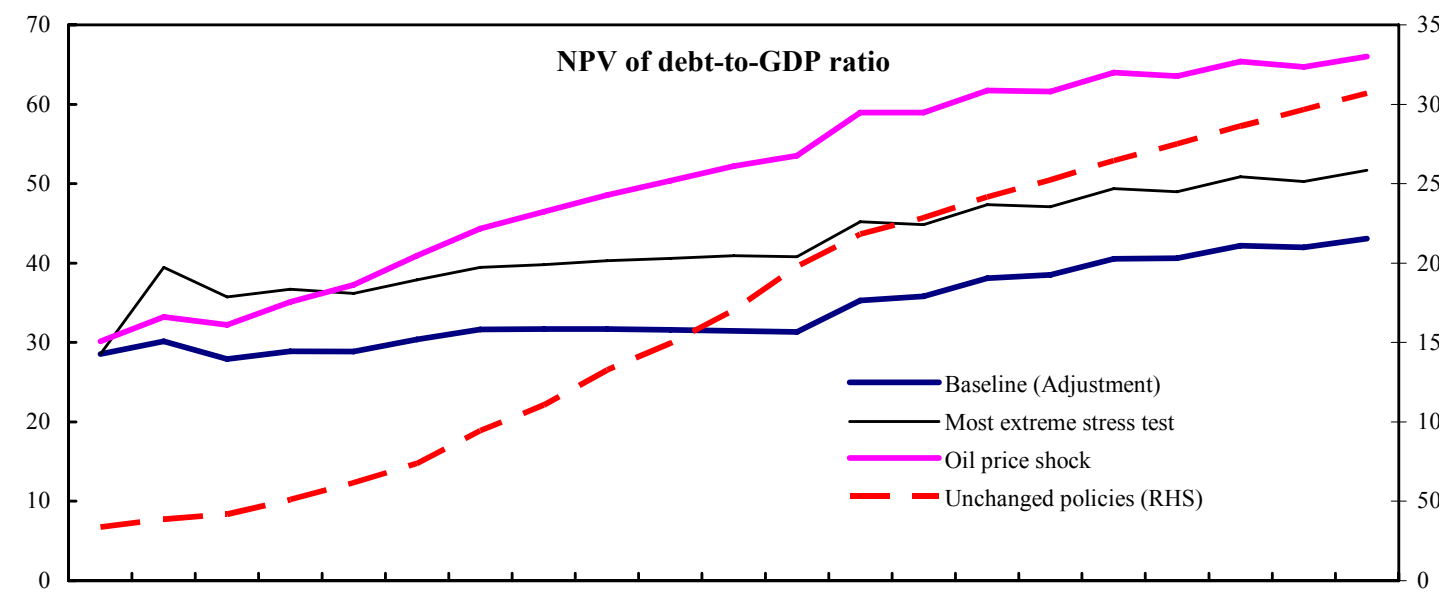

200720082009201020112012201320142015201620172018201920202021202220232024202520262027

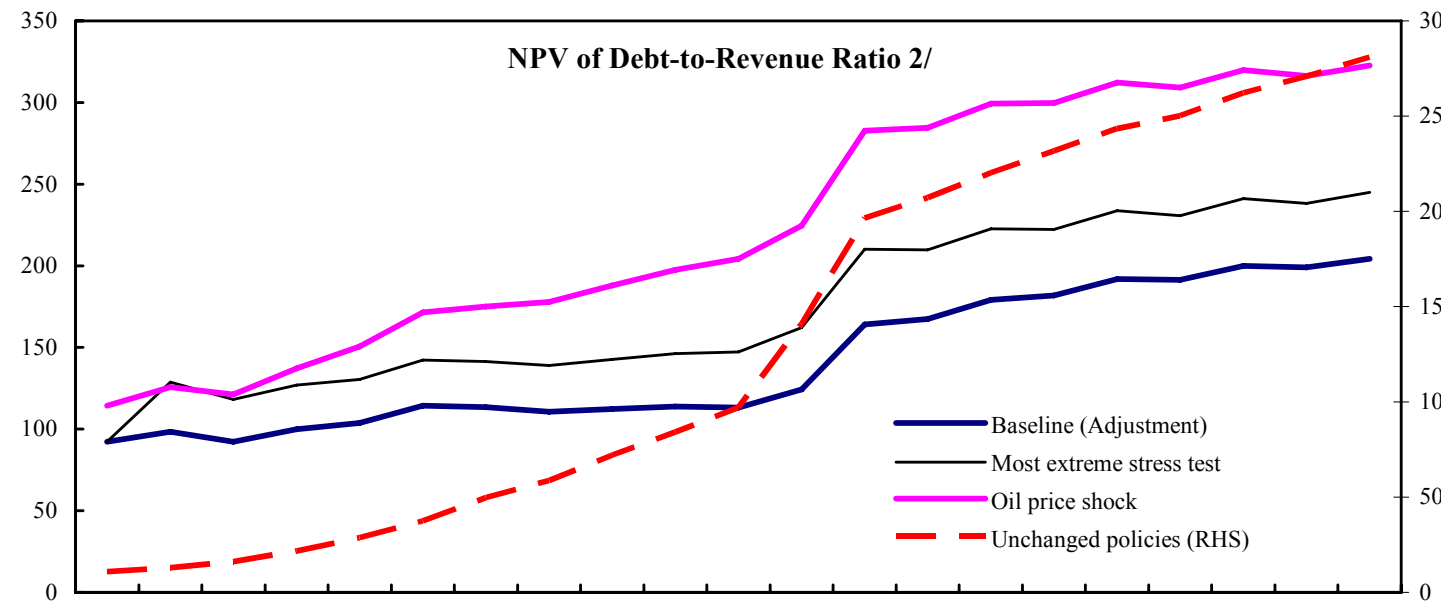

200720082009201020112012201320142015201620172018201920202021202220232024202520262027

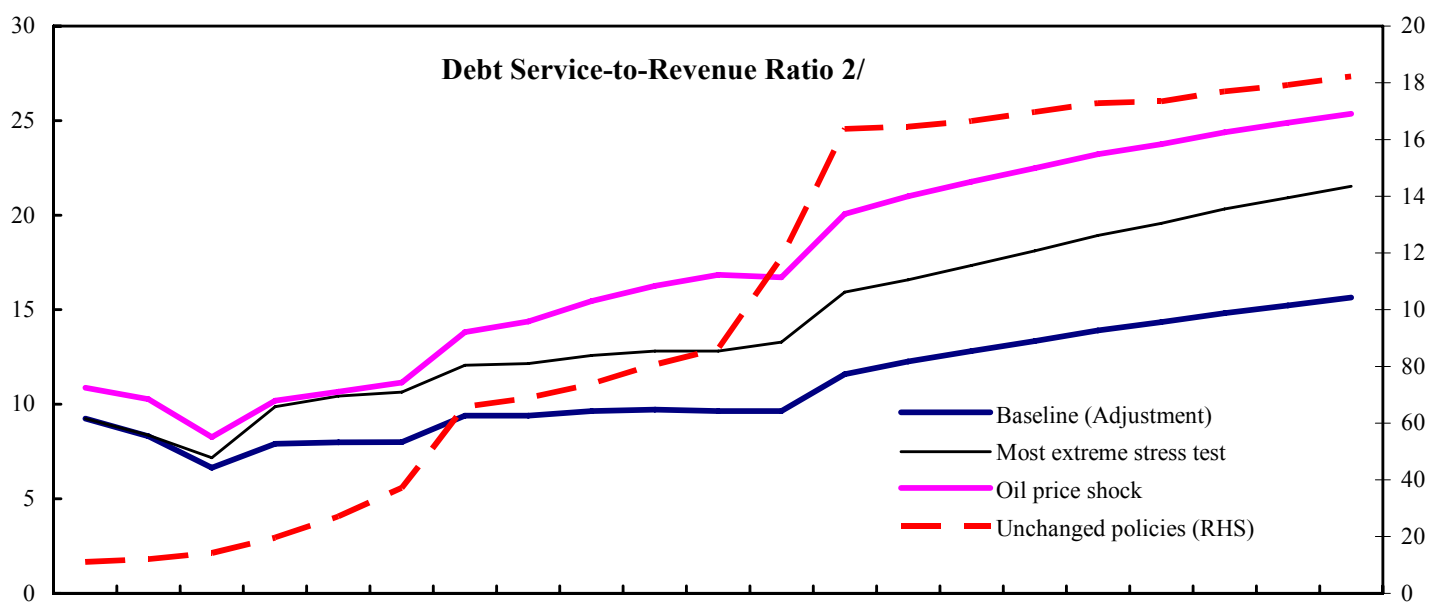

200720082009201020112012201320142015201620172018201920202021202220232024202520262027

Source: Staff projections and simulations.

1/ Most extreme stress test is test that yields highest ratio in 2017.

2/ Revenue including grants. 


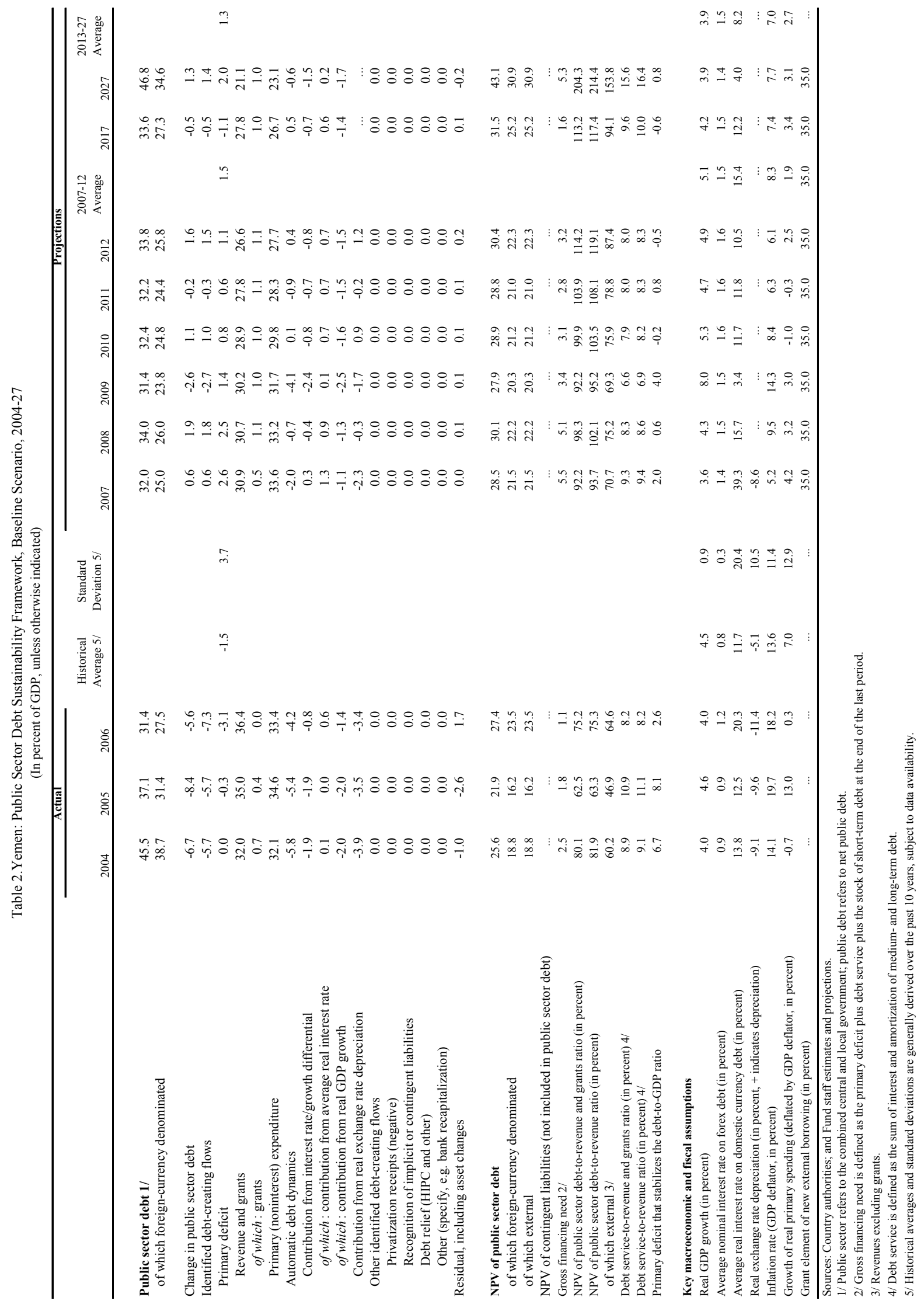


Table 3.Yemen: Sensitivity Analysis for Key Indicators of Public Debt 2007-27

NPV of Debt-to-GDP Ratio
Baseline
A. Alternative scenarios
A1. Real GDP growth and primary balance are at historical averages
A2. Primary balance is unchanged from 2007
A3. Permanently lower GDP growth $1 /$
A4. Permanently lower oil prices from 2007 ( 20 percent decline)
A5. Unchanged policies
B. Bound tests
B1. Real GDP growth is at historical average minus one standard deviations in 2008-2009
B2. Primary balance is at historical average minus one standard deviations in 2008-2009
B3. Combination of B1-B2 using one half standard deviation shocks
B4. One-time 30 percent real depreciation in 2008
B5. 10 percent of GDP increase in other debt-creating flows in 2008

NPV of Debt-to-Revenue Ratio 2/

Baseline

\section{A. Alternative scenarios}

A1. Real GDP growth and primary balance are at historical averages A2. Primary balance is unchanged from 2007

A3. Permanently lower GDP growth 1/

A4. Permanently lower oil prices from 2007 (20 percent decline)

A5. Unchanged policies

\section{B. Bound tests}

B1. Real GDP growth is at historical average minus one standard deviations in 2008-2009

B2. Primary balance is at historical average minus one standard deviations in 2008-2009

B3. Combination of B1-B2 using one half standard deviation shocks

B4. One-time 30 percent real depreciation in 2008

B5. 10 percent of GDP increase in other debt-creating flows in 2008

Debt Service-to-Revenue Ratio 2/

Baseline

\section{A. Alternative scenarios}

A1. Real GDP growth and primary balance are at historical averages

A2. Primary balance is unchanged from 2007

A3. Permanently lower GDP growth $1 /$

A4. Permanently lower oil prices from 2007 (20 percent decline)

A5. Unchanged policies

\section{B. Bound tests}

B1. Real GDP growth is at historical average minus one standard deviations in 2008-2009

B2. Primary balance is at historical average minus one standard deviations in 2008-2009

B3. Combination of B1-B2 using one half standard deviation shocks

B4. One-time 30 percent real depreciation in 2008

B5. 10 percent of GDP increase in other debt-creating flows in 2008

\section{Projections}

\begin{tabular}{llllllll}
2007 & 2008 & 2009 & 2010 & 2011 & 2012 & 2017 & 2027 \\
\hline
\end{tabular}

$\begin{array}{llllllll}29 & 30 & 28 & 29 & 29 & 30 & 31 & 43\end{array}$

$\begin{array}{rrrrrrrr}29 & 27 & 25 & 25 & 24 & 24 & 23 & 14 \\ 29 & 30 & 29 & 31 & 32 & 34 & 45 & 56 \\ 29 & 30 & 28 & 29 & 29 & 31 & 34 & 50 \\ 30 & 33 & 32 & 35 & 37 & 41 & 52 & 66 \\ 34 & 39 & 42 & 51 & 62 & 74 & 170 & 307\end{array}$

$\begin{array}{llllllll}29 & 31 & 30 & 32 & 33 & 35 & 40 & 57 \\ 29 & 30 & 28 & 29 & 29 & 31 & 32 & 43 \\ 29 & 29 & 27 & 28 & 28 & 30 & 31 & 43 \\ 29 & 39 & 36 & 37 & 36 & 38 & 41 & 52 \\ 29 & 37 & 33 & 34 & 33 & 35 & 37 & 47\end{array}$

$\begin{array}{llllllll}92 & 98 & 92 & 100 & 104 & 114 & 113 & 204\end{array}$

$\begin{array}{rrrrrrrr}92 & 90 & 82 & 86 & 86 & 90 & 81 & 69 \\ 92 & 98 & 95 & 106 & 115 & 128 & 161 & 265 \\ 92 & 99 & 93 & 101 & 106 & 117 & 122 & 236 \\ 114 & 126 & 121 & 137 & 151 & 171 & 204 & 323 \\ 109 & 130 & 160 & 217 & 287 & 375 & 971 & 2808\end{array}$

$\begin{array}{rrrrrrrr}92 & 99 & 100 & 111 & 118 & 132 & 145 & 269 \\ 92 & 98 & 93 & 101 & 105 & 115 & 114 & 205 \\ 92 & 94 & 90 & 98 & 102 & 112 & 110 & 201 \\ 92 & 129 & 118 & 127 & 130 & 142 & 147 & 245 \\ 92 & 120 & 109 & 117 & 120 & 132 & 132 & 224\end{array}$

Sources: Country authorities; and Fund staff estimates and projections.

$1 /$ Assumes that real GDP growth is at baseline minus one standard deviation divided by the square root of 20 (i.e., the length of the projection period).

2/ Revenues are defined inclusive of grants. 
Figure 2. Yemen: Indicators of Public and Publicly Guaranteed External Debt

Under Alternative Scenarios, 2007-27
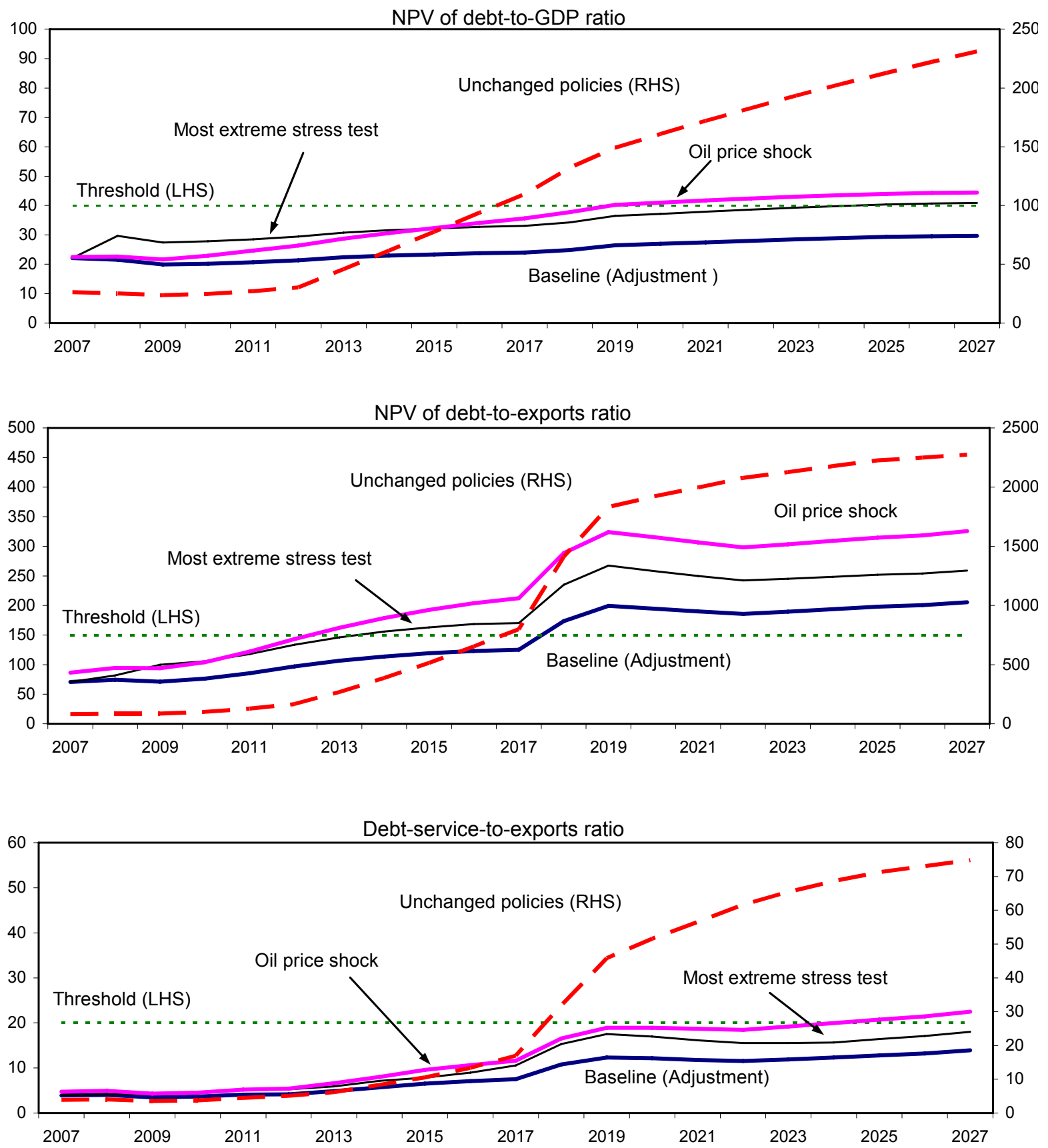

Source: Fund staff projections and simulations.

Note: Thresholds on right axis are suppressed. 


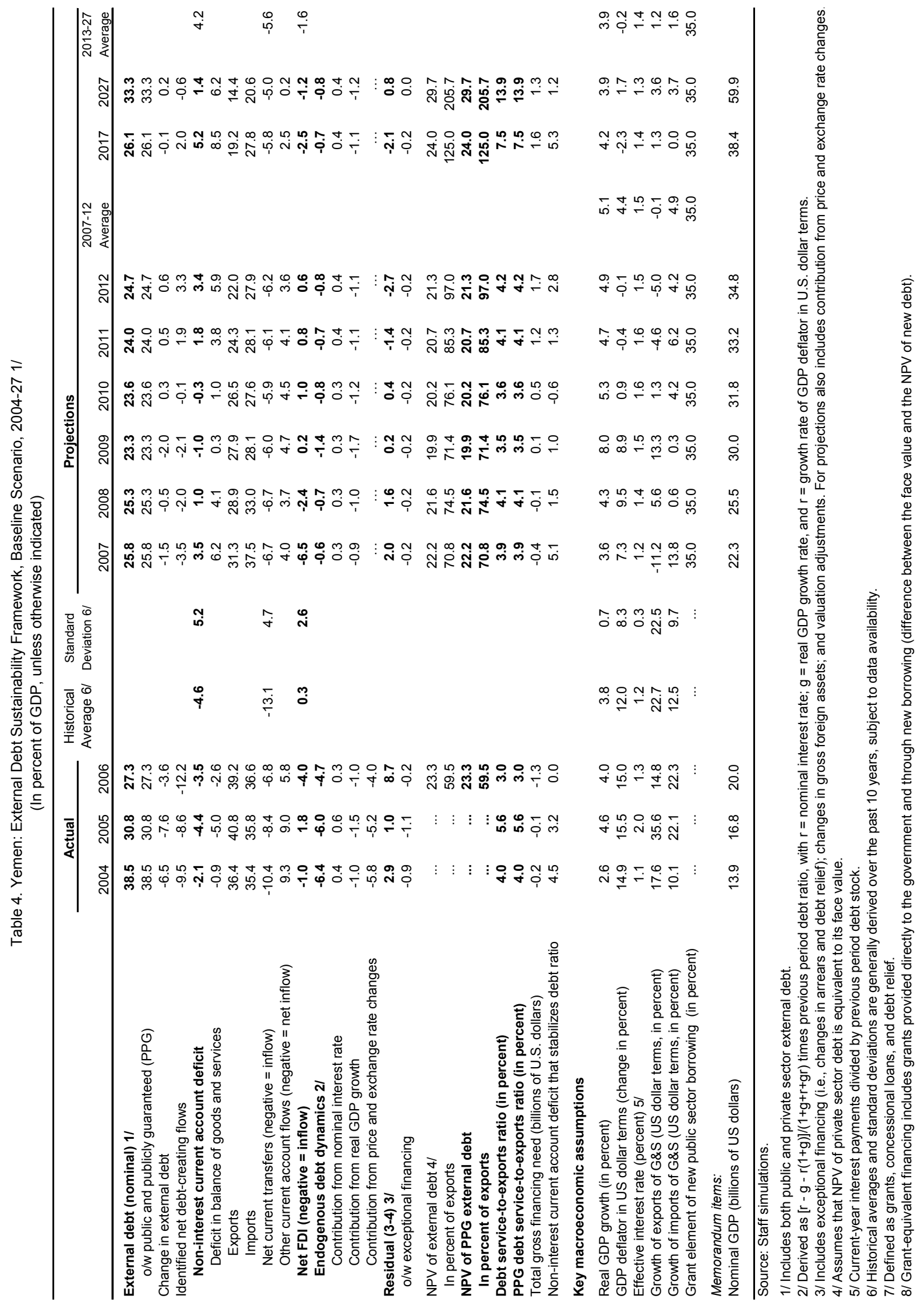


Table 5. Yemen: Sensitivity Analyses for Key Indicators of Public and Publicly Guaranteed External Debt, 2007-27 (In percent)

\begin{tabular}{|c|c|c|c|c|c|c|c|c|}
\hline & \multicolumn{8}{|c|}{ Projections } \\
\hline & 2007 & 2008 & 2009 & 2010 & 2011 & 2012 & 2017 & 2027 \\
\hline \multicolumn{9}{|c|}{ NPV of debt-to-GDP ratio } \\
\hline Baseline & 22 & 22 & 20 & 20 & 21 & 21 & 24 & 30 \\
\hline \multicolumn{9}{|l|}{ A. Alternative Scenarios } \\
\hline A1. Key variables at their historical averages in 2008-27 1/ & 22 & 19 & 16 & 12 & 7 & 2 & 0 & 0 \\
\hline A2. New public sector loans on less favorable terms in $2008-27$ 2/ & 22 & 22 & 21 & 22 & 22 & 24 & 28 & 39 \\
\hline A3. Permanently lower oil prices from 2007 (20 percent decline) & 22 & 23 & 22 & 23 & 25 & 26 & 36 & 44 \\
\hline A4. Unchanged policies & 26 & 25 & 24 & 25 & 27 & 30 & 110 & 231 \\
\hline \multicolumn{9}{|l|}{ B. Bound Tests } \\
\hline B1. Real GDP growth at historical average minus one standard deviation in 2008-09 & 22 & 22 & 21 & 21 & 22 & 23 & 25 & 31 \\
\hline B2. Export value growth at historical average minus one standard deviation in 2008-09 3/ & 22 & 22 & 23 & 24 & 24 & 25 & 27 & 31 \\
\hline B3. US dollar GDP deflator at historical average minus one standard deviation in 2008-09 & 22 & 23 & 22 & 22 & 23 & 24 & 27 & 33 \\
\hline B4. Net non-debt creating flows at historical average minus one standard deviation in 2008-09 4/ & 22 & 24 & 22 & 22 & 23 & 23 & 26 & 31 \\
\hline B5. Combination of B1-B4 using one-half standard deviation shocks & 22 & 19 & 15 & 16 & 16 & 17 & 20 & 29 \\
\hline B6. One-time 30 percent nominal depreciation relative to the baseline in 2008 / & 22 & 30 & 27 & 28 & 29 & 29 & 33 & 41 \\
\hline
\end{tabular}

\section{NPV of debt-to-exports ratio}

Baseline

\section{A. Alternative Scenario}

A1. Key variables at their historical averages in 2008-26 1/

A2. New public sector loans on less favorable terms in 2008-26 2/

A3. Permanently lower oil prices from 2007 (20 percent decline)

A4. Unchanged policies

\section{B. Bound Tests}

B1. Real GDP growth at historical average minus one standard deviation in 2008-09 B2. Export value growth at historical average minus one standard deviation in 2008-09 3/

B3. US dollar GDP deflator at historical average minus one standard deviation in 2008-09

B4. Net non-debt creating flows at historical average minus one standard deviation in 2008-09 4/

B5. Combination of B1-B4 using one-half standard deviation shocks

B6. One-time 30 percent nominal depreciation relative to the baseline in 20085 / $\begin{array}{llllllll}71 & 75 & 71 & 76 & 85 & 97 & 125 & 206\end{array}$

$\begin{array}{rrrrrrrr}71 & 67 & 58 & 46 & 30 & 11 & \mathbf{0} & 0 \\ 71 & 77 & 75 & 81 & 93 & 107 & \mathbf{1 4 5} & 270 \\ 87 & 94 & 94 & 104 & 122 & 143 & \mathbf{2 1 2} & 326 \\ 83 & 86 & 87 & 101 & 129 & 166 & 798 & 2275\end{array}$

$\begin{array}{rrrrrrrr}71 & 75 & 71 & 76 & 85 & 97 & \mathbf{1 2 5} & 206 \\ 71 & 82 & 100 & 106 & 118 & 134 & \mathbf{1 7 0} & 259 \\ 71 & 75 & 71 & 76 & 85 & 97 & \mathbf{1 2 5} & 206 \\ 71 & 82 & 79 & 84 & 94 & 107 & \mathbf{1 3 6} & 213 \\ 71 & 60 & 49 & 53 & 60 & 69 & \mathbf{9 2} & 180 \\ 71 & 75 & 71 & 76 & 85 & 97 & \mathbf{1 2 5} & 206\end{array}$

\section{Debt service-to-exports ratio}

\section{Baseline}

A. Alternative Scenarios

A1. Key variables at their historical averages in 2008-27 1/

A2. New public sector loans on less favorable terms in 2008-27 2/

A3. Permanently lower oil prices from 2007 ( 20 percent decline)

A4. Unchanged policies

\section{B. Bound Tests}

B1. Real GDP growth at historical average minus one standard deviation in 2008-09

B2. Export value growth at historical average minus one standard deviation in 2008-09 $3 /$

B3. US dollar GDP deflator at historical average minus one standard deviation in 2008-09

B4. Net non-debt creating flows at historical average minus one standard deviation in 2008-09 4/

B5. Combination of B1-B4 using one-half standard deviation shocks

B6. One-time 30 percent nominal depreciation relative to the baseline in 2008 5/

Memorandum item:

Grant element assumed on residual financing (i.e., financing required above baseline) $6 /$

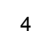

4

\section{4}

814

$\begin{array}{rrrrrrrr}4 & 4 & 3 & 3 & 3 & 2 & \mathbf{0} & 0 \\ 4 & 4 & 4 & 4 & 5 & 5 & \mathbf{9} & 19 \\ 5 & 5 & 4 & 5 & 5 & 5 & \mathbf{1 2} & 23 \\ 4 & 4 & 4 & 4 & 5 & 5 & 17 & 75\end{array}$

Source: Staff projections and simulations.

1/ Variables include real GDP growth, growth of GDP deflator (in U.S. dollar terms), non-interest current account in percent of GDP, and non-debt creating flows

2/ Assumes that the interest rate on new borrowing is by 2 percentage points higher than in the baseline., while grace and maturity periods are the same as in the baseline. 3/ Exports values are assumed to remain permanently at the lower level, but the current account as a share of GDP is assumed to return to its baseline level after the shock (implicitly assuming an offsetting adjustment in import levels).

4/ Includes official and private transfers and FDI.

$5 /$ Depreciation is defined as percentage decline in dollar/local currency rate, such that it never exceeds 100 percent.

6/ Applies to all stress scenarios except for A2 (less favorable financing) in which the terms on all new financing are as specified in footnote 2. 


\section{INTERNATIONAL MONETARY FUND}

\section{REPUBLIC OF YEMEN \\ Staff Report for the 2007 Article IV Consultation \\ Supplementary Information}

Prepared by the Staff Representatives for the 2007 Consultation

with the Republic of Yemen

Approved by Adam Bennett and Adnan Mazarei

September 13, 2007

1. This supplement summarizes information that has become available since the staff report for the 2007 Article IV consultation was circulated to the Board on August 20, 2007. The additional information alters the thrust of the staff appraisal regarding the fiscal and inflation outlook.

\section{RECENT ECONOMIC DEVELOPMENTS}

2. Twelve-month inflation (excluding qat) fell further to $\mathbf{1 0 . 2}$ percent in June, from 12 percent in May. The Consumer Price Index (excluding qat) rose by almost 4 percent in June, largely driven by higher prices of vegetables and edible oils, and to a lesser extent of wheat and flour.

3. In July and August, food prices, and especially of wheat and flour, are reported to have further increased sharply. This reflects, in part, the rapid rise in wheat prices in international markets during this period.

4. Violent protests erupted in several cities in Yemen during the last few weeks, with some reported fatalities. The protests were sparked by large price increases and high unemployment.

5. In response to the unrest, the authorities have announced measures aimed at alleviating the impact of rising prices. Government workers received a one-month salary bonus before Ramadan. In addition, the state-owned Yemen Economic Corporation, which supplies foodstuffs to the military, was instructed to increase its wheat imports and to sell them at cost to the general public. The authorities believe that wheat prices are partly driven up by noncompetitive behavior of the main private trading firms. To enhance competition, the authorities have also amended the Commercial Law to extend the right of importation of wheat to fully foreign-owned firms. A World Bank analysis conducted earlier this year of the operation of the markets for basic food staples, including wheat, however, did not find evidence of anti-competitive behavior. 
6. Since June, the Central Bank of Yemen (CBY) has stepped up its foreign exchange sales and the exchange rate of the rial vis-à-vis the U.S. dollar has remained broadly stable. This should help limit imported inflation somewhat. The net issuance of treasury bills has also increased in recent months, with the net amount issued in the first seven months of 2007 already reaching a level similar to that of 2006 as a whole. Preliminary fiscal data for the first half of the year suggest that the increased issuance reflects a widening fiscal deficit. Oil revenues have remained below budgeted amounts, despite the recent high oil prices.

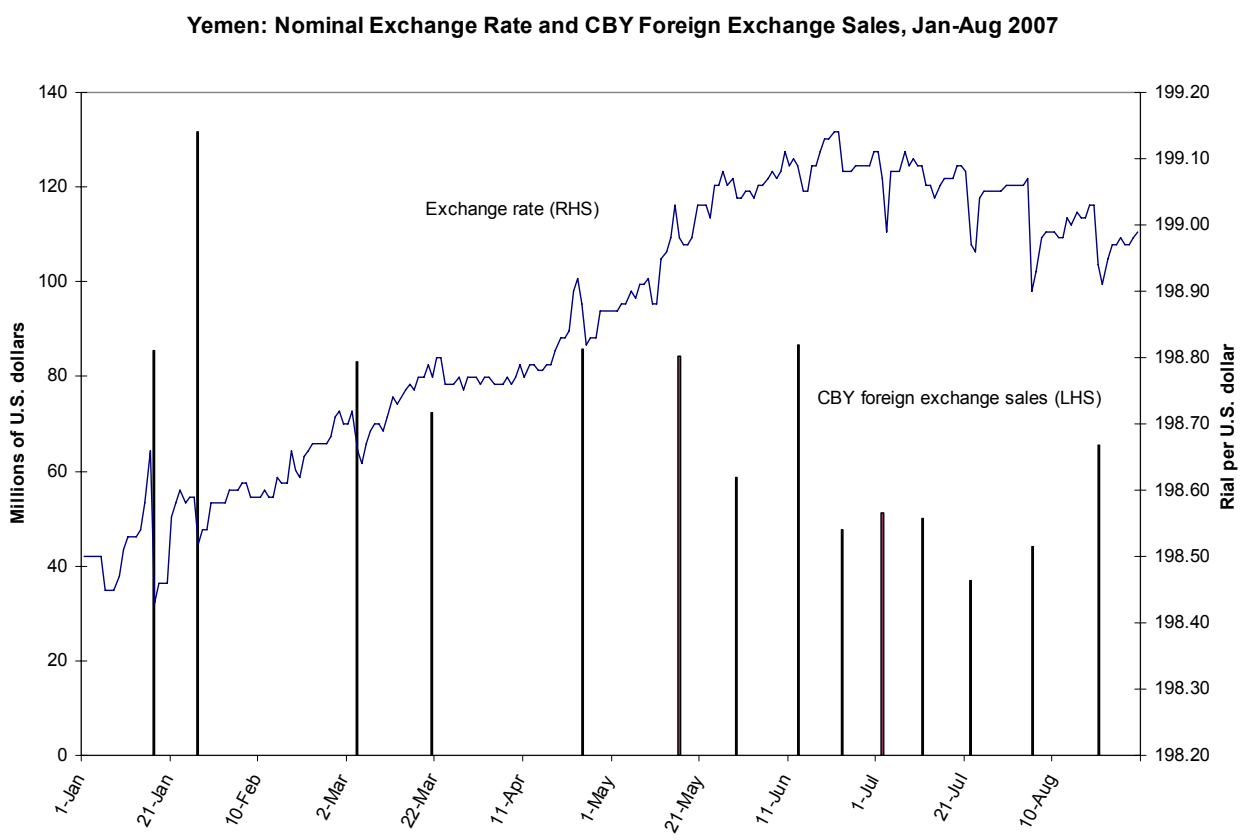

\section{Staff ApPRAisal}

7. The authorities' decision to grant a one-month bonus to government employees risks renewing inflationary pressures and makes achieving fiscal and debt sustainability more difficult. The bonus will increase the budget deficit by about 0.6 percent of GDP, to reach 5.2 percent of GDP in 2007. Last year, a similar bonus ahead of Ramadan helped push prices up by 6 percent in both September and October. Staff is concerned that the bonus could have a similar impact this year and drive inflation back up to well over 15 percent by end-2007. Absent a stronger tightening of monetary policy, the target range of 12-14 percent for core inflation by end-2007 no longer appears achievable.

8. The government intervention in the wheat market should not have an impact on the budget, but risks displacing private sector import activity. Staff welcomes the authorities' efforts to further enhance competition in the markets for basic food staples, but urges them to withdraw from the wheat market as soon as possible. If the authorities wish to cushion the future impact of high wheat prices on the poor, it would be preferable to do so through the Social Welfare Fund, while continuing to address weaknesses in this system. 


\section{Statement by A. Shakour Shaalan, Executive Director for Republic of Yemen September 17, 2007}

1. At the outset, I would like to convey the Yemeni authorities' appreciation to the staff and management for the constructive relationship with the Fund. They particularly appreciate staff's collaborative engagement during the Article IV mission, and the valuable policy advice and technical assistance they continue to receive from the Fund. The authorities are mindful of the broad challenges facing the economy in the medium and longer terms, and look forward to continued dialogue on the policy priorities in the period ahead.

\section{Background}

2. A series of wide-ranging macroeconomic and structural reforms undertaken over the past decade helped engender an economic transformation in Yemen. Chief among these are the unification of the exchange rate, fiscal reforms, trade liberalization, privatization of public sector enterprises, and financial sector reforms. The Fund has played a critical role in assisting and promoting this process, which helped the country achieve steady progress. These deep structural reforms have been pursued alongside efforts to democratize the political process. Admittedly, tensions could sometimes arise between the desirability of an ambitious pace of economic reforms and the need to ensure their broader acceptance in the context of high levels of poverty and unemployment. From this perspective, the introduction of the General Sales Tax (GST) in 2007, as well as important structural reforms undertaken in various areas are notable accomplishments since last year's consultation.

3. Notwithstanding these accomplishments, the authorities are intent on deepening the economic transformation in order to address the challenges emanating from the prospective depletion of oil reserves and the weaknesses in human and physical capital. In view of the significant development needs, intensified donor support will be critical in sustaining the authorities' efforts to tackle problems of widespread poverty and limited institutional and implementation capacities. In this respect, the Consultative Group (CG) meeting in November 2006 in London was an important milestone, with pledges of about $\$ 5$ billion financing about 85 percent of the government's Public Investment Program for 2007-2010.

\section{Recent Developments}

4. Economic performance in 2006 continued to be broadly positive. Real GDP growth is estimated at 4 percent, with growth in the non-hydrocarbon sector more than offsetting a sizable contraction in oil production. Notwithstanding the latter, buoyant oil prices helped keep the overall budget broadly in balance, although the non-oil primary deficit registered a limited increase. Moreover, the external current account continued to register a modest surplus, and the surplus in the overall balance of payments contributed to a further increase in foreign exchange reserves, which reached almost $\$ 6.8$ billion at end-2006, covering about 11 months of imports. Both 
gross public debt and public external debt continued on a downward trajectory, declining to 40 percent and 27 percent of GDP, respectively. Nonetheless, average core inflation accelerated to 20 percent, in part reflecting higher world food prices, as well as domestic demand-induced pressures owing to higher government spending out of larger than projected oil revenues. Given pressing spending needs, additional oil revenues have been channeled essentially toward greater development expenditures, in addition to fuel subsidies to shield vulnerable groups from higher oil prices. With the abatement of seasonal pressures on inflation, due to a sharp drop in prices of basic food commodities and below-budget government spending, core inflation declined steeply to 12 percent in May 2007.

\section{Prospects and Policies}

5. The recent positive performance has not detracted the authorities' attention from the challenges in the period ahead. While the near-term outlook is broadly manageable, the authorities are aware of the need for tightened financial policies to bring core inflation down within the range of 12-14 percent by end-2007. Given the heavy weight of food components in the consumer price index, and the onset of food stocking for the religious month of Ramadan, the current juncture of persistent strength of world food prices would not realistically allow for an inflation rate below 10 percent in the period immediately ahead, as suggested by staff.

6. The authorities are also cognizant of the challenges posed by the prospective depletion of proven oil reserves over the medium and longer term. The coming onstream of liquefied natural gas (LNG) production will partly mitigate the negative drag on growth from declining oil output, and the implications for the fiscal and external accounts will only be modest. The outlook on oil production, however, could surprise on the upside, given the intensification of exploration and recovery efforts. Nevertheless, the authorities are committed to maintain fiscal and external sustainability by formulating fiscal policy within conservative estimates of proven reserves. Sustainability considerations, however, would need to be carefully balanced against the imperative of sustaining a minimum level of economic growth to facilitate diversification and support labor absorption and poverty reduction. Achieving these objectives could call for maintaining relatively high spending levels, at least over the medium term. Policy makers are thus confronted with competing pressures on government resources that require a delicate balancing act in the policy mix.

\section{Fiscal Policy and Reforms}

7. The 2007 budget initially envisaged an increase in the overall deficit to 6 percent of GDP, reflecting the persistence of spending pressures against a background of a sharp decline in oil revenues. Nonetheless, given inflationary pressures, the authorities have effected some degree of fiscal tightening from the initial plans. In this respect, implementation of the announced wage increase has been delayed until mid-2008 to coincide with the introduction of biometric cards. Additionally, non-wage current spending will be streamlined, while development spending financed by CG pledges will help offload some capital expenditure from the budget. Together these measures 
are expected to result in a reduction in the overall budget deficit by about 2 percent of GDP from the initial estimates.

8. The authorities share the view that a sizable consolidation effort is needed to ensure fiscal and debt sustainability over the medium and longer term as oil revenues taper off. They are in broad agreement with the balance of measures proposed by staff that emphasize increasing non-oil revenue intake and trimming government expenditures. On the revenue side, the GST has been successfully introduced in January 2007, with only limited exemptions, at the rate of 5 percent. The authorities remain committed to full implementation of the GST at 10 percent by 2009 as proposed by staff. However, they are of the view that it is important to ensure that the tax is effectively implemented and administered before proceeding with a rate increase. Moreover, a large tax payer unit has been established. Further efforts are contemplated to expand the revenue base, including the reduction of the corporate income tax rate from 35 percent to 20 percent to harmonize it with regional levels, and the elimination of exemptions in the income, customs, and investment laws.

9. On the expenditure side, the authorities are cognizant of the need to phase out fuel subsidies, although progress in this area is affected by political considerations. Fuel price increased in July 2005 had led to social unrest and considerable loss of life. Nonetheless, the authorities are committed to link the elimination of fuel subsidies with progress on measures to protect vulnerable groups from its adverse effects. In this vein, a revised social assistance law will be submitted to parliament before end2007 , as part of ongoing efforts to strengthen the targeting and coverage of the Social Welfare Fund, and to broaden the subsidy reduction and render it more politically acceptable.

10. Importantly, the authorities have taken decisive measures to address weaknesses in budget formulation and execution by embarking on a comprehensive two-year public financial management reform program, with the assistance of a group of donors. In this respect, a Medium-Term Expenditure Framework will be introduced, starting with the 2008 budget. Moreover, discussions are ongoing with a FAD technical assistance mission regarding the establishment of a single treasury account at the Ministry of Finance, which should further enhance control over spending.

11. The authorities appreciate the staff's debt sustainability analysis (DSA), which incorporates the updated information on LNG revenues and export receipts, and accounts for new disbursements pledged during the 2006 CG meeting. The DSA underscores the fragility of debt dynamics in Yemen. Even under the assumption of full implementation of the adjustment scenario proposed by staff, highly concessional financing would still be required to avert debt distress over the projection period. In this connection, and while pledges from the GCC countries, accounting for half of total pledges at the CG, are predominantly in grant form, the authorities are hopeful that disbursement of remaining pledges would be mindful of the need for a high degree of concessionality. 


\section{Monetary and Financial Sector Policies}

12. The Central Bank of Yemen (CBY) remains committed to the maintenance of price stability. However, the attempts at effecting a steady depreciation of the Yemeni rial, consistent with the gradual depletion of oil reserves, have resulted in an accommodative monetary stance in 2006. To help alleviate emerging inflationary pressures in 2007 , the authorities have agreed to tighten monetary policy. In this respect, and consistent with staff's advice, they have slowed the rate of depreciation of the rial and even allowed for a modest appreciation. Nevertheless, the authorities are mindful that reserve accumulation and competitiveness considerations would prevail once inflationary pressures subside, with the exchange rate resuming a market-determined path.

13. The CBY is aware of the limitations of the present monetary framework that aims at controlling inflation through the targeting of monetary aggregates. Given the shallow financial intermediation and relatively high deposit dollarization, there is limited scope for a more active interest rate policy as an effective instrument to control inflation. The authorities recognize that deepening financial intermediation and removing structural impediments to private sector credit growth are essential to promote non-oil sector activities. To help identify vulnerabilities and develop an agenda for reforms, they have expressed interest in a Financial Sector Stability Update. In addition, a revised Anti Money Laundering law, prepared partly under the assistance of the Fund, is to be submitted to parliament for approval.

\section{Other Structural Reforms}

14. With oil production on a declining trend, the Yemeni government has stepped up efforts to diversify the economy and promote alternative sources of growth and employment generation. While the gas sector is of major strategic importance for Yemen, there is concurrent focus on strategies to promote the development of the country's tourism and maritime activities, to capitalize on the coastal location and cultural heritage. The authorities are aware that significant levels of investment are required for the effective development of these sectors. To this end, a number of initiatives have been undertaken to strengthen the investment climate. In particular, tax and administration reforms which resulted in the elimination of production taxes on businesses have earned Yemen the title of top reformer in 2005/06 according to the 2007 Doing Business Report. Moreover, and to further strengthen transparency in the oil sector, the authorities intend to join the Extractive Industries Transparency Initiative. Efforts will also be directed at strengthening the economy's regional linkages, particularly with the GCC countries, and global integration, through ongoing discussions on accession to the World Trade Organization. 


\section{INTERNATIONAL MONETARY FUND}

EXTERNAL

Public Information Notice

RELATIONS

DEPARTMENT

Public Information Notice (PIN) No. 07/120

FOR IMMEDIATE RELEASE

September 27, 2007

International Monetary Fund

$70019^{\text {th }}$ Street, NW

Washington, D. C. 20431 USA

\section{IMF Executive Board Concludes 2007 Article IV Consultation with the Republic of Yemen}

On September 17, 2007, the Executive Board of the International Monetary Fund (IMF) concluded the Article IV consultation with the Republic of Yemen. ${ }^{1}$

\section{Background}

Despite recent progress in poverty reduction, Yemen remains one of the poorest countries in the region and is far from achieving the Millennium Development Goals. Oil production has been declining since 2000 , and in the absence of major discoveries, proven oil reserves could be depleted in some 10 years time. The start of a large liquefied natural gas project from 2009 will offer only partial compensation. Yemen faces considerable challenges to generate strong (nonhydrocarbon) growth to absorb the rapidly growing labor force and raise living standards, while ensuring fiscal and external stability in the context of declining oil reserves.

Economic performance in 2006 was generally favorable, but was accompanied by an increase in inflation. Overall real GDP growth reached 4 percent in 2006, with a 6 percent non-oil growth offsetting an 8 percent decline in oil production. After a decade of relatively stable rates in the 10-12 percent range, core inflation (excluding the volatile prices of the narcotic qat) increased to over 20 percent. This was partly due to higher world food prices, but buoyant domestic demand driven by increased government spending and rapid money growth, played a major role.

\footnotetext{
${ }^{1}$ Under Article IV of the IMF's Articles of Agreement, the IMF holds bilateral discussions with members, usually every year. A staff team visits the country, collects economic and financial information, and discusses with officials the country's economic developments and policies. On return to headquarters, the staff prepares a report, which forms the basis for discussion by the Executive Board. At the conclusion of the discussion, the Managing Director, as Chairman of the Board, summarizes the views of Executive Directors, and this summary is transmitted to the country's authorities.
} 
High oil prices helped reduce the overall budget deficit to about $1 / 2$ percent of GDP in 2006, but spending remained high. As in previous years, a large supplementary budget was issued at the end of the year to validate spending overruns that had already taken place. Fuel subsidies continued to absorb a large part of the budget (8 percent of GDP) and the wage bill rose to over 9 percent of GDP, while the non-oil tax ratio fell further to less than 7 percent of GDP. Without corrective actions, the overall deficit would significantly widen in 2007 (to 5-7 percent of GDP) as the approved budget maintains high spending levels despite lower oil revenues due to declining production and prices.

Monetary policy was accommodative in 2006. With sizable government spending out of high oil revenues, the real exchange rate appreciated by 10 percent in 2006. The Central Bank of Yemen (CBY) continued its policy of targeting a slow and steady depreciation of the exchange rate, so the real appreciation manifested itself through higher inflation. Money growth accelerated to 28 percent in 2006, twice the rate of the previous two years.

The external account surplus remained broadly unchanged at over 3 percent of GDP in 2006, with record-high oil receipts partially offset by imports related to sizable investments in the gas sector. With the latter financed trough foreign direct investment, the high oil revenues resulted in a large reserve accumulation by the CBY. Gross reserves at the CBY increased by $\$ 1.5$ billion to $\$ 6.8$ billion by year end, the equivalent of about 11 months of imports.

Relations with the international community have strengthened. A Consultative Group meeting held in November 2006 in London succeeded in generating almost $\$ 5$ billion in pledges (about one-fourth of 2006 GDP), underwriting a large part of Yemen's Public Investment Program for 2007-10. Half of the pledges came from Gulf Cooperation Council countries. Also, Yemen was reinstated in the U.S.'s Millennium Challenge Corporation's threshold program. The Yemeni authorities recently committed to join the Extractive Industries Transparency Initiative.

\section{Executive Board Assessment}

The Executive Board welcomed Yemen's generally favorable recent economic performance, including the decline in the poverty rate, as well as the progress being made on a number of structural reforms. Nevertheless, Directors concurred that the authorities face considerable macroeconomic and structural policy challenges to promote strong economic growth, create ample employment opportunities, and reduce poverty, while ensuring fiscal and external sustainability. In this regard, Directors welcomed the authorities' strategy of basing policies on existing hydrocarbon reserves, while recognizing that the country's economic outlook could be significantly altered by the discovery of new oil and gas resources.

Directors, noting that inflationary pressures have not fully abated, were encouraged by the authorities' commitment to reducing inflation. They agreed that monetary policy should focus closely on price stability and welcomed the CBY recent efforts to keep the exchange rate of the rial vis-à-vis the U.S. dollar broadly stable, which should help limit imported inflation. Given the limitations of monetary policy in Yemen, Directors generally considered it to be appropriate for the $\mathrm{CBY}$ to continue to rely substantially on the exchange rate as a nominal anchor, in order to 
achieve lower inflation. While the exchange rate currently appears to be broadly in line with fundamentals, over time and in view of the expected decline in oil production, it will be important for the exchange rate to reflect evolving economic conditions.

Directors observed that the shallow financial intermediation, along with a relatively high level of dollarization, is limiting the effectiveness of monetary policy. They viewed that the removal of the minimum interest rate for rial deposits would allow the CBY to conduct a more active interest rate policy and enhance financial intermediation.

Directors noted that fiscal restraint, including public sector wage restraint, should provide an important complement to monetary policy in reducing inflationary pressures. They also underscored that frontloading fiscal adjustment will be needed, given the prospective decline in oil production and revenues.

Directors agreed that the gradual phasing out of domestic fuel subsidies will be central to fiscal adjustment, while recognizing that this will require political support. They noted that raising fuel prices should go hand-in-hand with strengthening the social safety net, in order to cushion the impact on the poor, including through persevering with ongoing efforts aimed at improving the Social Welfare Fund. Directors also were of the view that, if the authorities wished to cushion the impact of high wheat prices on the poor, it would be preferable to do so through the SWF. Strong efforts will also be needed to increase the government's non-oil revenues, reorient spending towards priority areas, and improve the quality and effectiveness of capital spending. Directors supported the progress being made towards strengthening the budgetary framework and improving fiscal transparency.

Directors underscored the importance of productivity-enhancing reforms to strengthen Yemen's competitiveness in non-oil exports. Further efforts are needed to improve the investment climate and the quality of labor, enhance governance and reduce red tape, including in tax and customs administration. Directors stressed that deepening financial markets will be essential for ensuring strong non-oil performance, and also recommended further strengthening of banking supervision. In this regard, they encouraged the authorities to request an Financial Sector Assessment Program update, which would help to assess potential risks in the financial system and to develop an agenda for financial sector reforms. Directors welcomed the revised Anti-Money Laundering law, and looked forward to its approval by parliament.

Directors looked forward to further efforts to improve the quality and timeliness of macroeconomic statistics, to better facilitate the formulation and monitoring of economic policies. 
Public Information Notices (PINs) form part of the IMF's efforts to promote transparency of the IMF's views and analysis of economic developments and policies. With the consent of the country (or countries) concerned, PINs are issued after Executive Board discussions of Article IV consultations with member countries, of its surveillance of developments at the regional level, of post-program monitoring, and of ex post assessments of member countries with longer-term program engagements. PINs are also issued after Executive Board discussions of general policy matters, unless otherwise decided by the Executive Board in a particular case. The staff report (use the free Adobe Acrobat Reader to view this pdf file) for the 2007 Article IV Consultation with Ireland is also available. 
Republic of Yemen: Basic Economic and Financial Indicators, 2003-07

Quota $=$ SDR 243.5 million

Population $=21.6$ million $(2006)$

Per capita GDP: US\$ 927 (2006)

\begin{tabular}{|c|c|c|c|c|c|}
\hline & 2003 & 2004 & 2005 & $\frac{\text { Prel }}{2006}$ & $\frac{\text { Proj }}{2007}$ \\
\hline & & \multicolumn{4}{|c|}{ (Change in percent) } \\
\hline \multicolumn{6}{|l|}{ National Income and Prices } \\
\hline Real GDP & 3.7 & 4.0 & 4.6 & 4.0 & 3.6 \\
\hline Real nonhydrocarbon GDP & 4.8 & 5.4 & 5.3 & 5.7 & 5.2 \\
\hline Real hydrocarbon GDP & -2.1 & -5.0 & -0.8 & -8.3 & -10.1 \\
\hline Core consumer price index (end-of-period) $1 /$ & 12.1 & 14.5 & 20.2 & 22.0 & 12.0 \\
\hline & & \multicolumn{4}{|c|}{ (In millions of U.S. dollars) } \\
\hline \multicolumn{6}{|l|}{ External sector } \\
\hline Exports, f.o.b & 3,924 & 4,676 & 6,413 & 7,285 & 6,377 \\
\hline of which: hydrocarbons & 3,417 & 4,303 & 5,952 & 6,733 & 5,814 \\
\hline Imports, f.o.b & 3,557 & 3,859 & 4,713 & 5,890 & 7,118 \\
\hline Current account, incl. official transfers (in percent of GDP) & 1.5 & 1.6 & 3.8 & 3.2 & -3.8 \\
\hline \multirow[t]{2}{*}{ Overall balance (deficit-) } & 583 & 556 & 264 & 1,353 & 1,104 \\
\hline & & \multicolumn{4}{|c|}{ (In percent of GDP) } \\
\hline \multicolumn{6}{|l|}{ Fiscal variables } \\
\hline Overall balance (cash basis) 2/ & -5.3 & -1.7 & -0.3 & -0.2 & -4.6 \\
\hline Nonhydrocarbon primary fiscal balance (cash) 2/ & -25.7 & -22.1 & -24.4 & -25.4 & -24.9 \\
\hline \multicolumn{6}{|l|}{ Debt ratios } \\
\hline Net public debt & 52.2 & 45.5 & 37.1 & 31.4 & 32.0 \\
\hline \multirow[t]{2}{*}{ External debt } & 45.0 & 38.5 & 30.8 & 27.3 & 25.8 \\
\hline & & \multicolumn{4}{|c|}{ (12-month change in percent) } \\
\hline Broad money & 20.0 & 15.0 & 14.4 & 28.8 & 25.0 \\
\hline Credit to private sector & 26.3 & 33.5 & 21.3 & 16.7 & 12.5 \\
\hline Benchmark deposit interest rate (percent per annum) & 13.0 & 13.0 & 13.0 & 13.0 & $\ldots$ \\
\hline \multicolumn{6}{|l|}{ Central bank own gross foreign reserves $3 /$} \\
\hline In millions of U.S. dollar & 4,449 & 5,068 & 5,338 & 6,798 & 7,975 \\
\hline In months of next year's imports of goods and services & 15.2 & 15.0 & 11.0 & 10.8 & 12.6 \\
\hline
\end{tabular}

Source: Yemeni authorities; and staff estimates and projections.

$1 /$ Core CPI is defined as the overall CPI less the CPI for qat.

2/ Includes statistical discrepancy.

3 / Gross reserves minus commercial bank and pension fund foreign exchange deposits held with the central bank. 